\title{
When Firms Talk, Do Investors Listen? The Role of Trust in Stock Market Reactions to Corporate Earnings Announcements *
}

\author{
Mikhail Pevzner \\ George Mason University \\ Fei Xie \\ Clemson University \\ Xiangang Xin \\ City University of Hong Kong
}

January 16, 2013

\footnotetext{
* M. Pevzner can be reached at mpevzner@gmu.edu, F. Xie can be reached at xief@clemson.edu, and X. Xin can be reached at xiangxin@ cityu.edu.hk. We thank Nick Seybert, Tao Shu, Min Shen, Cong Wang, Min Zhu, participants at the 2012 Washington D.C. Summer Accounting Symposium, and especially an anonymous referee for helpful comments that significantly improved the paper.
} 


\title{
When Firms Talk, Do Investors Listen? The Role of Trust in Stock Market Reactions to Corporate Earnings Announcements
}

\begin{abstract}
We examine whether the level of trust in a country affects investors' perception and utilization of information transmitted by firms through financial disclosure. Specifically, we investigate the effect of societal trust on investor reactions to corporate earnings announcements. We test two competing hypotheses: on the one hand, corporate earnings announcements are perceived as more credible by investors in more trusting societies and therefore elicit stronger investor reactions; on the other hand, societal trust mitigates outside investors' concern of moral hazard and reduces the value of corporate earnings announcements to them, thereby weakening their reactions to these events. We analyze the abnormal trading volume and abnormal stock return variance during the earnings announcement period in a large sample of firm-year observations across 25 countries, and find that both measures of investor reactions to earnings announcements are significantly higher in more trusting countries. We also find that the positive effect of societal trust on investor reactions to earnings news is more pronounced (1) when a country's investor protection and disclosure requirements are weaker, suggesting that trust acts as a substitute for formal institutions, (2) when a country's average education level is lower, consistent with less educated people relying more on trust in making economic decisions, and (3) when firm level information asymmetry is higher, supporting the notion that trust plays a more important role in poorer information environments.
\end{abstract}




\section{Introduction}

Earnings announcements represent one of the most important channels of communication between a firm's managers or insiders and outside investors. How effective these disclosure mechanisms are in transmitting value-relevant information to outside investors and how capital market participants perceive and react to this information have been the subject of a large and growing body of research in finance and accounting (e.g., Beaver (1968), Diamond and Verrecchia (1991), Kim and Verrecchia (1991a, b, 1994), Harris and Raviv (1993), Kandel and Pearson (1995), Bamber, Christensen, and Gaver (2000), Bailey, Karolyi, and Salva (2006), Landsman and Maydew (2002), and DeFond, Hung, and Trezevant (2007)). In particular, one stream of literature (e.g., Alford et al. (1993), Ali and Hwang (2000), Hung (2000), and DeFond, Hung, and Trezevant (2007)) investigates the cross-country variations in investors' reaction to corporate earnings announcements around the world and identifies several structural factors such as investor protection, earnings quality, and financial reporting frequency, as among the chief determinants of such variations.

In this paper, we examine whether the stock market reaction generated by earnings announcements is related to one important country characteristic that has so far eluded prior research, i.e., the level of societal trust in a country. Gambetta (1988) defines trust as the subjective probability that an individual assigns to the event of a potential counterparty performing an action that is beneficial or at least not harmful to that individual, and it is a key element of culture and social capital (Putnam (1993), Fukuyama (1995), and Guiso, Sapienza, and Zingales $(2006,2010)) .{ }^{1}$ Consistent with the notion that trust underlies virtually all economic exchanges (Williamson (1993)), it has been shown that a higher level of trust facilitates economic growth and social efficiency (La Porta et al. (1997), Knack and Keefer (1997), and Zak and Knack (2001)), international trade and investment (Guiso, Sapienza, and Zingales (2009)), financial development (Guiso, Sapienza, and Zingales (2004, 2008)), and corporate financing and M\&A

\footnotetext{
${ }^{1}$ Guiso, Sapienza, and Zingales (2006, 2010) synthesize and improve upon a number of different definitions of culture and social capital proposed in the sociology and economics literatures. They define culture as "customary beliefs and values that ethnic, religious, and social groups transmit fairly unchanged from generation to generation," and social capital as "persistent and shared beliefs and values that help a group overcome the free rider problem in the pursuit of socially valuable activities."
} 
transactions (Bottazzi, Da Rin, and Hellmann (2011), Duarte, Siegel, and Young (2010), and Ahern, Daminielli, and Fracassi (2012)). ${ }^{2}$ Yet, the impact of trust on the effectiveness of information transmission from managers to outside investors remains an unexplored issue. This is surprising considering that much of the corporate governance reforms and regulations enacted in the aftermath of the corporate scandals at Enron and WorldCom in early 2000s (e.g., the Sarbanes-Oxley Act of 2002) were aimed at restoring investor trust in corporations in general and corporate financial reporting and disclosure in particular. ${ }^{3}$ Economic theory also suggests that trust can play an important role in the interaction between managers and outside investors given incomplete contracting and the potential for moral hazard (Williamson (1993), Guiso, Sapienza, and Zingales (2008), and Carlin, Dorobantu, and Viswanathan (2009)). Self-serving managers have incentives to obfuscate reported financial results in an attempt to conceal their firm's true performance and obstruct investors' monitoring activities (Leuz, Nanda, and Wysocki (2003)). Recognizing such incentives, investors rationally view and react to firms' financial reporting with a certain dose of reservation. Trust, which reflects "the subjective probability individuals attribute to the possibility of being cheated" (Guiso, Sapienza, and Zingales (2008)), clearly has the potential to influence investors' attitude toward and reaction to corporate earnings announcements, but as we argue below, its actual impact can be difficult to predict ex ante.

On the one hand, a key determinant of the stock market reaction to a firm's release of accounting information is the perceived credibility of the information. Prior research establishes that higher perceived credibility of reported earnings enhances stock market's reaction to earnings announcements. For example, the stock market reacts more strongly to earnings announcements by firms employing higher quality auditors (e.g., Balsam, Krishnan, and Yang (2003) and Teoh and Wong (2003)) and to voluntary disclosure by firms that have established a reputation for credible voluntary disclosure (Rogers and Stocken (2005)). We expect that in countries with a higher level of societal trust, investors assign a lower probability to managers behaving opportunistically and manipulating financial results. Therefore, they

\footnotetext{
${ }^{2}$ See Guiso, Sapienza, and Zingales $(2006,2010)$ for excellent reviews of the literature on the effects of culture and social capital on economic outcomes.

${ }^{3}$ See, e.g., "Sarbanes-Oxley law has been a pretty clean sweep," USA Today, July 29, 2007.
} 
perceive firms' financial reporting as more credible, and thus respond more vigorously to the information contained in corporate earnings announcements.

On the other hand, the reaction that earnings announcements are able to generate in the capital market also depends on outside investors' desire or need for information. It is well recognized that managers often do not act in the best interest of shareholders due to the separation of ownership and control (Jensen and Meckling (1976)) and this agency conflict is exacerbated by the information asymmetry between managers and shareholders (Myers and Majluf (1984)). Among other objectives, one purpose of corporate financial reporting is to provide outside investors with information that they can use to evaluate and monitor the decision making of managers. Therefore, investors are more likely to closely follow a firm's earnings announcements and react strongly to the information therein when they face greater information asymmetry and perceive a higher probability of managerial opportunism. To the extent that shareholders in more trusting countries are less concerned about expropriation by corporate insiders and are more likely to hold the view that managers are trustworthy and forthright (Guiso, Sapienza, and Zingales (2008)), they may pay less attention to earnings announcements. As a result, we predict that trust may in fact subdue investors' reaction to earnings news.

We examine the two competing hypotheses in a large sample of about 53,000 firm-year observations across 25 countries spanning the years from 1995 to 2008 . Following prior studies such as La Porta et al. (1997) and Guiso, Sapienza and Zingales (2008), we capture a country's level of societal trust by its citizens' average response to a question in World Value Surveys (WVS), “Generally speaking, would you say that most people can be trusted or that you need to be very careful in dealing with people?"4 We measure investors' reaction to earnings announcements by abnormal return variance and abnormal trading volume around earnings announcements, as both theory and evidence show that return volatility and trading volume generated by earnings announcements increase with the precision and

\footnotetext{
${ }^{4}$ As noted by Guiso, Sapienza, and Zingales (2010), an individual's response to this question captures her level of generalized trust, i.e., trust toward generic members of the population in her own country. In robustness analysis, we find that our results continue to hold when we use a measure that captures individuals' confidence in corporations. Since corporations are ultimately run by individuals, we choose to use the generalized trust measure in most of our analysis.
} 
importance of the new information announced (e.g., Diamond and Verrecchia (1991), Kim and Verrecchia (1991a, b, 1994), Harris and Raviv (1993), Kandel and Pearson (1995), Bamber, Christensen, and Gaver (2000), Bailey, Karolyi, and Salva (2006), Landsman and Maydew (2002), DeFond, Hung, and Trezevant (2007), and Landsman, Maydew, and Thornock (2012)). ${ }^{5}$ To the extent that trust improves the perceived credibility and hence the precision and importance of the new information from the investors' perspective, we expect a positive relation between trust and abnormal return volatility and trading volume. On the other hand, a negative relation may emerge if investors in more trusting countries have less demand for information and thus pay less attention to earnings announcements.

We find significant evidence that investors in more trusting countries respond more strongly to corporate annual earnings announcements, consistent with the hypothesis that financial reporting by firms in more trusting countries is perceived by investors as more credible. Our findings are robust to controlling for country-level investor protection, disclosure requirements, insider trading law enforcement, stock market development, as well as firm-level characteristics and many other dimensions of culture.

We next investigate an alternative explanation for the positive relation between trust and investor reaction to earnings announcements. Specifically, in order for a higher level of societal trust to be an equilibrium outcome in a country, we expect that managers of firms in that country indeed engage in less shareholder expropriation. Therefore, they may have less incentive to manipulate accounting information to hinder shareholder monitoring. As a result, the quality of earnings is likely to be better in high trust countries and higher-quality earnings generate stronger investor reactions. This conjecture suggests that trust has an indirect effect on investor reactions to earnings news through improving earnings quality, while our hypothesis is based on how investors perceive corporate financial disclosure and suggests that

\footnotetext{
${ }^{5}$ Kim and Verrecchia (1991a) model abnormal trading volume around earnings announcements as the result of individual belief revisions. Investors are assumed to have diverse beliefs prior to earnings announcements. Therefore, the arrival of new information will trigger different belief revisions among investors, who consequently have different portfolio rebalancing needs. This gives rise to more trading. Alternatively, Harris and Raviv (1993), Kim and Verrecchia (1994), and Kandel and Pearson (1995) assume that investors apply different likelihood functions or employ different information processing technologies to analyze the new information. This results in different interpretations of the same information and generates trading activities. The more precise and important the new information is to investors, the larger the belief revisions it triggers (Kim and Verrecchia (1991a)) and the greater the divergence in opinions it creates (Harris and Raviv (1993), Kim and Verrecchia (1994), and Kandel and Pearson (1995)).
} 
trust has a direct impact on investor reactions to earnings announcements, separate from its potential impact on accounting quality. In other words, the alternative explanation argues that social trust relates to managerial behavior, which impacts the quality of corporate financial reporting and its trustworthiness. Our hypothesis, on the other hand, appeals to the subjective component of individuals' trusting behavior and predicts that investors in a high trust country react to earnings news more vigorously than their counterparts in a low trust country, even when the quality of earnings is the same between the two countries. We do not consider the alternative explanation and our hypothesis as mutually exclusive and therefore expect both to contribute to the positive relation between trust and investor reactions to earnings news.

The results from our analysis are consistent with this view. Specifically, we find that trust indeed is positively associated with a country's aggregate earnings quality and that higher quality earnings generate stronger investor reactions. However, even holding earnings quality constant, we still find evidence of significantly stronger investor reactions to earnings announcements in more trusting countries. That trust has a direct effect on investor reactions that is independent of its relation with earnings quality supports our hypothesis that trust increases the perceived credibility of corporate financial reporting.

In further analysis, we examine the causal nature of the relation between societal trust and investor reaction to earnings announcements. As is typical of cross-country studies, it is difficult to draw a definitive conclusion that it indeed is trust that leads to stronger investor reactions to corporate earnings announcements, since there are many country level characteristics (observable and unobservable) that are potentially related to both trust and stock market reaction to corporate financial disclosure. After all, trust as part of culture and social capital does not develop in a vacuum; instead, its formation and accumulation/depreciation are interconnected with history, politics, religion, ethnicity, personal upbringing, education, and formal institutions (Aghion et al. (2010), Glaeser, Laibson, and Sacerdote (2002), and Guiso, Sapienza, and Zingales $(2006,2010))$. We take two approaches to address this concern. We first resort to the theoretical development in the trust literature and explore whether the relation between trust and investor reaction to earnings announcements displays any cross-country or cross-firm 
variations as theory predicts. Consistent with extant theory and evidence, we find that the positive effect of trust on measures of investor reaction is more pronounced (i) in countries with poor investor protection and lax disclosure requirements, (ii) in countries with a lower average level of education, and (iii) for firms associated with greater information asymmetry. These findings suggest, respectively, that trust acts as a substitute for formal institutions at the country level (Guiso, Sapienza, and Zingales (2004), Carlin, Dorobantu, and Viswanathan (2009), and Aghion et al. (2010)), less educated people rely more on trust in making economic decisions (Guiso, Sapienza, and Zingales (2008, 2009), and trust plays a more important role in opaque information environments (Guiso, Sapienza, and Zingales (2008)).

While the cross-sectional variation evidence points to a casual interpretation that higher trust leads to greater investor reactions to earnings announcements, we more directly address the causality issue by estimating two-stage least squares (2SLS) regressions where we instrument trust by a country's primary religious belief. La Porta et al. (1997) and Guiso, Sapienza and Zingales (2006, 2008) argue that religion is more primitive than cultural values and can be considered exogenous. In addition, religion is a subjective characteristic of individuals that affects their level of trust and is separate from a country's objective characteristics such as investor protection, disclosure requirements, and law enforcement that can determine trust. We find that our results continue to hold after correcting for endogeneity.

We make two contributions to the literature. First, we identify societal trust as a new factor that can help explain cross-country variations in investors' reaction to corporate earnings announcements. This represents the first evidence on the broad issue of whether culture impacts investors' perception and utilization of financial information released by firms. Our findings imply that the capital market's reaction to corporate financial disclosure is impacted not only by formal institutions at the country level (see, e.g., Alford et al. (1993), Ali and Hwang (2000), Hung (2000), and DeFond, Hung, and Trezevant (2007)) but also by informal ones such as culture and, in particular, social trust. In addition, by documenting the effect of trust on the information transmission from firms to outside investors, we add to the existing literature on how trust affects various economic activities and exchanges. 
Second, our results indicate that trust affects investors' trading behavior around an important information event that is annual earnings announcements. The positive effect of trust on investor reaction to these announcements suggests that in more trusting countries, accounting information released by firms is impounded into security prices more quickly. This potentially leads to more efficient capital markets, which can enhance the efficiency of capital allocation in the economy and facilitate investments and economic growth. At the same time, firms in high trust countries may have more incentives to reveal private information to the market, knowing that investors are likely to perceive the information as more credible and react more strongly to it. This helps improve the information environment of firms and reduce costs of capital, thus enabling firms to make more positive-NPV investments and generate growth. These two avenues provide a partial explanation for the positive association between trust and investment and economic growth previously documented in the literature (Knack and Keefer (1997) and Zak and Knack (2001)).

The remainder of our paper is organized as follows. Section 2 develops testable hypotheses. Section 3 describes our research design and sample. Section 4 presents the empirical results. Section 5 concludes.

\section{Hypotheses development}

While there is a large literature examining the role of a country's formal institutions such as investor protection and accounting standards in explaining capital markets' reactions to corporate financial disclosure (e.g., Alford et al. (1993), Ali and Hwang (2000), Hung (2000), Landsman and Maydew (2002), DeFond, Hung, and Trezevant (2007), Landsman, Maydew, and Thornock (2012)), research has been scarce on whether cultural dimensions at the country level influence investors' perception and utilization of accounting information. According to Guiso, Sapienza, and Zingales (2006), culture represents "customary beliefs and values that ethnic, religious, and social groups transmit fairly unchanged from generation to generation." Among the many aspects of culture, trust has received arguably the most attention in the economics and finance literature because of its fundamental role of 
underlying virtually all economic transactions. Recent research shows that trust promotes investments, trade, and economic growth, encourages financial development and investors' participation in the stock market, and facilitates venture capital investment, corporate financing, and cross-border mergers and acquisitions (Knack and Keefer (1997) and Zak and Knack (2001), Guiso, Sapienza, and Zingales (2004, 2008), Bottazzi et al. (2011), Duarte et al. (2010) and Ahern et al. (2012)). Trust also influences adoption of more strict regulation as members of low trust societies demand more protection from the government (Aghion et al. (2010)). These studies point to the notion that trust is important in establishing credibility in contracting relationships and that it is particularly critical when the transactional horizon is finite and economic agents have limited ability to punish each other for misbehavior.

How trust affects investors' perception and utilization of corporate financial disclosure has been an unexplored issue and the actual impact is less than clear cut ex ante. On the one hand, we expect that in countries with a higher level of societal trust, investors assign a lower probability to managers behaving opportunistically and manipulating financial results. As a result, they perceive firms' financial reporting as more credible, and thus respond more vigorously to the information contained in corporate earnings announcements. On the other hand, the reaction that earnings announcements are able to generate in the capital market also depends on outside investors' demand for information. One goal of corporate financial reporting is to provide information that outside investors can use to evaluate and monitor the decision making of managers, who may not act in the best interest of shareholders given the separation of ownership and control at public corporations. Therefore, investors are likely to follow a firm's earnings announcements more closely and react to the information therein more vigorously when they perceive greater information asymmetry and a higher probability of managerial opportunism. To the extent that shareholders in more trusting countries are less worried about being expropriated by corporate insiders and are more likely to hold the view that managers are trustworthy and forthright (Guiso, Sapienza and Zingales (2008)), they may pay less attention to earnings announcements. Therefore, we may observe weaker investor reactions to these events. 
Given that trust can either strengthen or weaken the reactions that earnings announcements generate in the stock market, we state our first hypothesis as non-directional:

\section{H1: Societal trust affects investors' reaction to corporate earnings announcements.}

Economic theory suggests that the relation between trust and investor reactions to earnings announcements may vary with country and firm-level characteristics. In particular, studies in the trust literature (Williamson (1993), Carlin, Dorobantu, and Viswanathan (2009), Guiso, Sapienza, and Zingales (2004), and Aghion et al. (2010)) either argue or show that trust and formal institutions are substitutes. In our context, prior research (Leuz, Nanda, and Wysocki (2003)) finds that stronger investor protection and disclosure requirements reduce managerial incentives to distort financial reporting and improve earnings quality. As the quality of earnings improves, it becomes easier for investors to decipher the information contained in earnings announcements, diminishing their reliance on trust and thus the role of trust in explaining investors' perception and utilization of earnings information. In other words, we predict a substitutive relationship between trust and country-level institutions including investor protection and disclosure requirements and expect trust to be a more important determinant of investors' reactions to earnings announcements in countries with weak investor protection and lax disclosure requirements. This represents our second hypothesis, which is stated in a non-directional manner:

H2: The relation between trust and investor reactions to earnings announcements depends on a country's formal institutions such as investor protection and disclosure requirements.

The reliance of investors on trust in interpreting and reacting to corporate financial disclosure may also depend on their sophistication. Guiso, Sapienza, and Zingales (2008, 2009) find that less educated people rely more on trust in making economic decisions. Therefore, we expect trust to be a more important factor driving investor reaction to corporate earnings announcement when the average 
education level of a country's population is lower. This represents our third hypothesis, which is stated in a non-directional manner:

H3: The relation between trust and investor reactions to earnings announcements depends on a country's average education level.

The effect of trust on investor reaction to earnings announcements may also depend on firm-level information asymmetry. Trust is more important when there is more uncertainty and less information is available about counter-parties (Guiso, Sapienza, and Zingales (2008)). This suggests that higher ex-ante information asymmetry enhances the effect of trust on investors' reaction to a firm's earnings announcements. We phrase this prediction as our fourth hypothesis and state it non-directionally:

H4: The relation between trust and investor reactions to earnings announcements depends on the level of a firm's ex-ante information asymmetry.

\section{Research design and sample}

\subsection{Research design}

To test H1, we estimate the following baseline regression model:

$$
\text { Market Reaction }_{i}=a_{0}+a_{1} * \text { Trust }+\sum_{2}^{k} a_{i} * \text { Control }_{i}+e_{i}
$$

where Market Reaction is the reaction generated by a firm's annual earnings announcement in the domestic stock market, measured by either abnormal returns variance or abnormal trading volume around the announcement date, Trust captures the level of societal trust in the firm's country derived from the World Values Survey (WVS), and Control $_{\mathrm{i}}$ is a vector of control variables. ${ }^{6}$ We define all of these

\footnotetext{
${ }^{6}$ In regressing the stock market reactions to a firm's earnings announcement against the level of trust in the firm's country, we assume that domestic investors are the primary drivers of the market reaction. This is not an
} 
variables in greater detail below. H1 predicts $a_{1}$ to be positive (negative) if societal trust enhances (reduces) investors' reaction to earnings information.

To test $\mathrm{H} 2$, we estimate the following regression model:

$$
\begin{gathered}
\text { Market Reaction }_{i}=a_{0}+a_{1} * \text { Trust }+a_{2} * \text { Weak Formal Institutions }+a_{3} * \text { Weak Formal } \\
\text { Institutions } * \text { Trust }+\sum_{4}^{k} a_{i} * \text { Control }_{i}+e_{i}
\end{gathered}
$$

where Weak Formal Institutions is an indicator variable equal to one if the strength of a country's formal institutions such as investor protection and disclosure requirements is below the sample median. Our focus is on the coefficient $a_{3}$ which we predict to be positive if societal trust and formal institutions are substitutes.

We examine $\mathrm{H} 3$ by estimating the regression model specified below:

$$
\begin{aligned}
\text { Market Reaction }_{i} & =a_{0}+a_{1}{ }^{*} \text { Trust }+a_{2} * \text { Low Education }+a_{3} * \text { Low Education } * \text { Trust } \\
& +\sum_{4}^{k} a_{i} * \text { Control }_{i}+e_{i}
\end{aligned}
$$

where Low Education is an indicator variable equal to one if the average education level of a country's population is below the sample median. We expect the coefficient $a_{3}$ to be positive if less educated investors rely more on trust in understanding and reacting to corporate earnings announcements.

To test H4, we estimate the following regression model:

$$
\begin{aligned}
& \text { Market Reaction }_{i}= a_{0}+a_{1} * \text { Trust }+a_{2} * \text { High Information Asymmetry }+a_{3} * \text { High } \\
& \text { Information Asymmetry } * \text { Trust }+\sum_{4}^{k} a_{i} * \text { Control }_{i}+e_{i}
\end{aligned}
$$

where High Information Asymmetry is an indicator variable equal to one if a firm's information asymmetry measures are greater than their respective sample medians. According to H4, the coefficient of

unreasonable assumption given (i) the "home bias" in investors' international portfolio allocation decisions (French and Poterba (1991)), and (ii) the potential informational advantage possessed by domestic investors over their foreign counterparts (Coval and Moskowitz (1999)), which makes their reaction to earnings news more timely and accurate. We also show in Section 4.7 that our results are robust to excluding countries with high foreign institutional ownership. 
interest $a_{3}$ is positive if societal trust plays a more important role when firms are associated with greater information asymmetry.

We estimate all regressions controlling for year and industry fixed effects. All continuous variables are winsorized at their respective $1^{\text {st }}$ and $99^{\text {th }}$ percentiles to reduce the influence of outliers. Consistent with prior studies such as DeFond, Hung, and Trezevant (2007), Landsman, Maydew, and Thornock (2012) and Lang, Lins, and Maffett (2012), standard errors are adjusted for heteroskedasticity and firm level clustering (Petersen (2009)). ${ }^{7}$

\subsection{Sample construction}

Our sample spans a 14-year period from 1995 to 2008. We begin our sample construction process with all the firms in $\mathrm{I} / \mathrm{B} / \mathrm{E} / \mathrm{S}$ with annual earnings announcement dates. Since Bloomberg provides more accurate earnings announcement dates than I/B/E/S (Barber, De George, Lehavy, and Trueman (2012) and Grifin, Hirschey, and Kelly (2009)), we further collect earnings announcement dates from Bloomberg for our sample firms and replace the I/B/E/S earnings announcement dates with Bloomberg earnings announcement dates whenever the latter are available. We then compare earnings announcement dates with fiscal year end dates and drop announcements that are made more than 150 days after the fiscal yearend, since such delayed announcements are likely to be problematic (Barber, De George, Lehavy, and Trueman (2012)).

We obtain reported annual earnings and analyst forecasts information from $\mathrm{I} / \mathrm{B} / \mathrm{E} / \mathrm{S}$ and other necessary information such as firm size, reporting frequency, and cross listing status from Worldscope. After that, we match our sample with Datastream and obtain daily stock return and trading volume data over the window $(-120,+1)$ with the earnings announcement date being day 0 .

We then combine country-level variables with firm-level variables. We construct measures of trust and other cultural dimensions based on responses to the World Value Surveys (WVS). The survey was carried out in five waves in 1981-1984, 1989-1993, 1994-1998, 1999-2004, and 2005-2008.

\footnotetext{
${ }^{7}$ Our results remain qualitatively similar when we cluster standard errors at the country level.
} 
Following prior studies (e.g., Ahern, Daminelli, and Fracassi (2012)), we match the most recent cultural values to our firm-level variables. We further collect other country-level variables through various sources. In particular, we obtain each country's anti-self-dealing index from Djankov et al. (2008), the rule of law index from Kaufmann, Kraay, and Mastruzzi (2003), the disclosure requirement index from La Porta et al. (2006), and the dates of first insider trading law enforcement from Bhattacharya and Daouk (2002). After all these procedures our sample comprises 53,362 firm-year observations in 25 countries.

\subsection{Variable definitions}

\subsubsection{Culture measures}

Following prior literature (e.g., La Porta et al. (1997), Guiso, Sapienza, and Zingales (2008), and Ahern, Daminelli, and Fracassi (2012)), we measure societal trust based on the following question from the WVS:

Generally speaking, would you say that most people can be trusted or that you need to be very careful in dealing with people?

We recode the response to this question to 1 if a survey participant reports that most people can be trusted and 0 otherwise and then calculate the mean of the response in each country year as our measure of societal trust.

Along with societal trust, we also control for two other dimensions of culture constructed using WVS data in our robustness tests, i.e. hierarchy and individualism. To measure national attitudes toward hierarchy versus egalitarianism we use the following question from the WVS:

People have different ideas about following instructions at work. Some say that one should follow one's superior's instructions even when one does not fully agree with them. Others say that one should follow one's superior's instructions only when one is convinced that they are right. With which of these two opinions do you agree?

\section{Should follow instructions}

2. Must be convinced first 
Countries where people are more likely to follow instructions without question are considered hierarchical. We recode the response to the above question to 1 if a survey participant agrees with the first opinion and 0 otherwise. We use the average response of survey participants in each country year to measure the degree of hierarchy in a society.

To measure individualism we use the following question from the WVS:

How would you place your views on this scale? 1 means you completely agree with the statement on the left; 10 means you agree completely with the statement on the right; and if your views fall somewhere in between, you can choose any number in between.

\section{Incomes should be made more equal}

2. We need larger income differences as incentives for individual effort

Countries that are more individualistic place greater weight on individual effort than on ensuring everyone's benefit. We rescale the response of each survey participant to this question to be between 0 and 1 with 0 representing completely agreeing with the first statement and 1 representing completely agreeing with the second statement. The average of the rescaled response in each country year is our measure of individualism.

\subsubsection{Market reaction measures}

We measure investor reactions to earnings announcements by the abnormal return variance and abnormal trading volume around the announcements. Abnormal return variance is equal to the average of the squared market model-adjusted daily returns over the event window $(0,+1)$ scaled by the stock return variance over the estimation window $(-120,-21){ }^{8}$ The market model is estimated over the estimation window (-120, -21). Specifically, firm $i$ 's market model-adjusted returns on day $t$ during the event window is computed as follows:

\footnotetext{
${ }^{8}$ We use the two-day event window $(0,+1)$ because annual earnings are generally reported on newswires on day 0 , and then newswire information is typically disseminated via sources such as the Wall Street Journal on day +1 . In the robustness section, we try several alternative event windows and obtain very similar results.
} 


$$
U_{i t}=R_{i t}-\left(\alpha_{i}+\beta_{i} R_{m t}\right)
$$

where $R_{i t}$ is the daily stock return of firm $i$ on day $t, R_{m t}$ is the daily market return of firm $i$ 's country on day $t$, and $\alpha_{i}$ and $\beta_{i}$ are firm $i$ 's market model estimates obtained from the estimation window. Stock return variance over the event window $(0,+1)$ then is calculated as the average of the squared market adjusted return, $U_{i t}^{2}$. The stock return variance over the estimation window $(-120,-21)$ equals the variance of the residual returns from the firm's market model estimated over the estimation window.

The abnormal trading volume is measured as the average trading volume over the event window $(0,+1)$ scaled by the average trading volume over the estimation window $(-120,-21)$, with trading volume defined as the number of shares of firm $i$ traded on day $t$ divided by the total number of shares outstanding of firm $i$ on day $t$.

\subsubsection{Control variables}

Following DeFond et al. (2007) and Landsman et al. (2012), we control for a wide array of country and firm characteristics that have been shown in the literature to affect the stock market reactions generated by earnings announcement. Our country-level controls include the following variables. Investor Protection is the sum of the anti-self-dealing index from Djankov et al. (2008) and the rule of law index from Kaufmann, Kraay, and Mastruzzi (2003) after we standardize both indices to be between 0 and 1 . The Disclosure Requirement index is from La Porta et al. (2006) and captures (1) a country's requirement (or the lack thereof) of the delivery of a prospectus to potential investors in advance of securities issuance, and the extent of affirmative disclosure requirements in the following five areas: (2) insiders' compensation; (3) ownership by large shareholders; (4) inside ownership; (5) contracts outside the normal course of business; and (6) transactions with related parties. Insider Trading is an indicator variable that equals one for the years after the first legal case was brought against insider trading in a country, and zero otherwise. We expect stronger investor reactions to earnings announcements in countries with more 
effective investor protection and more stringent disclosure requirements, as both measures can limit insiders' attempt to expropriate outside minority shareholders and lead to higher quality of reported earnings and more developed capital markets. ${ }^{9}$ To the extent that the enforcement of insider trading laws discourages future inside trading and leakage of earnings information to the market prior to its announcement, we expect earnings announcements to generate stronger investor reactions in years subsequent to the first inside trading law enforcement action in a country.

Our firm-level controls include the following variables. Firm Size is the natural logarithm of the market value of equity in thousands of US dollars at the beginning of the fiscal year. $|U E|$ is the absolute value of unexpected earnings defined as actual annual earnings minus the most recent mean analyst forecast scaled by the most recent stock price. Firm Leverage is total liabilities divided by total assets. Quarterly Reporting equals one if the firm has quarterly earnings reporting, and zero otherwise. Reporting Lag is the number of days from the fiscal year end to the earnings announcement date reported by Bloomberg. Largest 20 is an indicator variable which equals one if a firm is one of the largest 20 firms in its country. Cross Listing is an indicator variable which equals one if a firm's securities are cross-listed in the U.S. Forecast Dispersion is the standard deviation of analysts' earnings forecasts scaled by the most recent stock price. Forecast Number is the number of annual earnings forecasts reported by I/B/E/S. Loss is an indicator variable which equals one if $\mathrm{I} / \mathrm{B} / \mathrm{E} / \mathrm{S}$ reported actual earnings are negative.

\section{Empirical results}

\section{1. Summary statistics}

We report the year distribution of our sample observations in Panel A of Table 1. The number of annual observations more than doubled over our sample period, likely reflecting a gradual increase of analyst coverage over time. Panel B of Table 1 shows the country distribution of observations and the country averages of main variables. The total number of observations in a given country ranges from 100

\footnotetext{
${ }^{9}$ In the robustness section, we show that our results continue to hold if we include a country's stock market development and aggregate earning quality as additional controls. Given the clearly endogenous nature of these two variables, we choose not to include them in the main tables.
} 
for Thailand to 27,857 for the U.S. We find that the mean abnormal return variance is greater than one for each sample country and it varies widely across countries, with a low of 1.267 in Taiwan and a high of 4.876 in the UK. Both the magnitude and cross-country variations are consistent with other studies in the literature (e.g., DeFond et al. (2007)). A similar pattern can be found for abnormal trading volume. The level of societal trust also display large cross-country variations, with a low of 0.118 in Philippines and a high of 0.657 in Sweden. In general, abnormal return variance and abnormal trading volume are higher in countries with higher levels of societal trust. For example, Sweden has the highest level of societal trust in our sample, and the average abnormal return variance (abnormal trading volume) in Sweden is 4.054 (2.113), which is higher than most other countries. We also note that the U.S., the U.K. $(3,997)$ and Japan $(6,717)$ have the largest numbers of observations in our sample. In Section 4.2 we show that our results are not driven by the disproportionate presence of these three countries.

Panel A of Table 2 presents the summary statistics of main variables for the entire sample. We find the mean (median) abnormal return variance is 3.757 (1.244) and the mean (median) abnormal trading volume is 1.851 (1.377). For country level variables, the mean (median) value of Societal trust is 0.371 (0.363), mean (median) of Investor Protection is 1.405 (1.330), mean (median) of Disclosure Requirement is 0.880 (1.000). With respect to firm level variables, we find that the mean (median) of Firm Size in our sample is 13.684 (13.600), the mean (median) of $|U E|$ is 0.027 (0.004), the mean (median) Firm Leverage is 0.542 (0.549), the mean (median) of Reporting Lag is 50.883 (47.000) days, the mean (median) of Forecast Dispersion is 0.020 (0.005), and the mean (median) of Forecast Number is 8.269 (6.000). Moreover, $63.5 \%$ of the firms in our sample report quarterly earnings, $7.6 \%$ of the firms are cross listed in US, $14.0 \%$ of the firms report losses. These statistics are largely consistent with prior studies in the literature.

We report the Pearson (lower triangle) and Spearman (upper triangle) correlations of the main variables in Panel B of Table 2. The Pearson (Spearman) correlation between abnormal return variance and abnormal trading volume is $0.468(0.474)$, suggesting that these two variables capture similar but different dimensions of the information content of earnings announcements and the investor reactions 
they generate. We also find that societal trust is positively correlated with both abnormal return variance and abnormal trading volume. We rely on multivariate regressions in the following sections to test our hypotheses by controlling for other variables that may affect investor reactions to earnings announcements.

\subsection{Baseline regression results}

We test $\mathrm{H} 1$ by estimating the regression model specified in equation (1) and present the results in Table 3. In columns (1) and (2), we use the abnormal return variance to measure investors' reaction to earnings announcements. In column (1) where societal trust is the only explanatory variable other than year and industry fixed effects, we find that it has a significant and positive effect on abnormal return variance. In column (2), we control for a country's investor protection index and disclosure requirement index as well as firm characteristics. We find that the coefficient on societal trust remains positive and significant. In fact, both its statistical significance and magnitude become higher. These findings indicate that societal trust enhances investors' reactions to earnings announcements and support the notion that in more trusting countries, investors perceive firms' financial reporting as more credible and respond more strongly to it.

Our results are significant not only statistically but also economically. For example, in column (2), the coefficient on trust is 3.658 with a $t$-statistic of 8.06 and two-sided $p$-value of less than 0.01 . Based on this coefficient, all else being equal, one standard deviation increase in trust increases the abnormal return variance by 0.278 , which amounts to $22 \%$ of the sample median.

In columns (3) and (4) of Table 3, we replace abnormal return variance with abnormal trading volume as the measure of investor reaction to earnings announcements and re-estimate the regression model specified in equation (1). The tenor of the results is essentially the same as in columns (1) and (2); social trust has a significant and positive effect on investor reactions to corporate earnings announcements.

With respect to control variables, we find that investor protection and disclosure requirements are both significantly and positively associated with investor reactions to earnings announcements measured 
by either abnormal return variance or abnormal trading volume. In addition, investors react less strongly to annual earnings announcements by larger firms and firms with more frequent reporting and a longer reporting lag and they respond more strongly when unexpected earnings are higher. We also find that investor reactions decrease with analyst forecast dispersion and increase with the number of analysts following a company. Finally, investors respond less to announcements of negative earnings. These results are generally in line with findings in prior research (e.g. DeFond et al (2007) and Landsman et al (2012)).

In the robustness analysis presented later in the paper, we also control for two country-level disclosure quality measures. One is the earnings quality index constructed by Leuz et al. (2003) and the other is the Center for International Financial Analysis Research (CIFAR) index of transparency introduced by La Porta et al. (1998). The former captures the extent of earnings management behavior by firms in a country and the latter represents the average number of ninety items included in the annual reports of companies in a country. We find that both disclosure quality measures display significant and positive relations with abnormal return variance and abnormal trading volume. More importantly, societal trust continues to have a significantly positive effect on investor reactions to corporate earnings announcements. This result is important in that it sheds light on the specific channels through which trust enhances investor reactions to earnings announcements. As mentioned in the introduction, trust can result in higher earnings quality if it reduces managers' tendency to engage in self-serving behavior and distort financial reporting, and/or it can also increase the perceived credibility of corporate financial reporting from the perspective of investors. Either of the two mechanisms can lead to a positive relation between trust and investor reaction to earnings announcements. However, our finding that societal trust retains its positive and significant coefficient even when we explicitly control for earnings quality measures suggests that one channel at work is that trust increases the perceived credibility of the accounting information released by firms and thus investors react more strongly to it. In Section 4.3, we perform a path analysis to better understand the channels through which trust enhances investor reaction to corporate earnings announcements. 


\subsection{Path analysis of the effect of trust on investor reactions to earnings news}

In this section, we perform a path analysis to further examine the mechanisms through which trust influences market reaction to earnings announcements. A path analysis models exogenous variables as having both direct effects on endogenous variables and indirect effects through some mediating variables (Wright (1934)). This allows us to separate the two possible channels through which trust enhances investor reactions to earnings announcements. More specifically, we can test whether the positive relation between trust and investor reaction to earnings news is due to trust increasing the perceived credibility of corporate financial reporting on its own, or due to trust improving earnings quality and higher quality earnings subsequently generating stronger investor reactions. In the first channel, trust is hypothesized to have a direct effect on investor reaction to earnings, while in the second channel trust is assumed to have an indirect effect on investor reactions to earnings announcements with earnings quality as a mediating variable.

In performing the path analysis, we estimate a structural equation model (SEM) of the direct effect of trust on market reaction to earnings news as well as the indirect effect of trust on market reaction to earnings news. In addition to earnings quality, we also choose reporting lag and analyst coverage as mediating variables, since both have been shown in the literature to affect market reaction to earnings. ${ }^{10}$ The SEM analysis includes (1) a regression of market reaction to earnings news on trust and mediating variables (reporting lag, analyst following, and earnings quality) and (2) regressions of the three mediating variables on trust, with a number of control variables included in all regression equations.

Table 4 reports the results from the path analysis. The indirect effect of trust on the market reaction measures is the product of the effect of trust on the mediating variables and the effect of mediating variables on the market reaction measures. The significance of the indirect effect is estimated

\footnotetext{
${ }^{10}$ See, for example, Chambers and Penman (1984), Atiase et al (1989), Piotroski and Roulstone (2004), Christensen et al (2004), and Landsman, Maydew, and Thornock (2012). In unreported analysis, we also include analyst forecast dispersion and reporting frequency as additional mediating variables. We do not find any significance relation between them and societal trust, and the rest of our results are unchanged by their inclusion in the structural equation model.
} 
using the Sobel (1982) test statistics. In Panel A, the market reaction measure is the abnormal return variance (Abvar). We find that trust has significant indirect effects on market reaction to earnings announcement through all three mediating variables. In particular, the coefficient of Trust on Earnings quality is 0.126 and the coefficient of Earnings quality on Abvar is 1.910 . Both coefficients are highly significant and give rise to an indirect coefficient of Trust on Abvar that is 0.241 with a robust $t$-statistic of 7.14. This suggests that trust has a significant indirect effect on investor reactions to earnings announcements through impacting earnings quality. However, we also find that trust has a direct effect on abnormal return variance that is significant and positive, as evidenced by the direct coefficient of Trust on Abvar of 2.183 with a robust $t$-statistic of 4.93 . This result lends support to the explanation that the financial reporting by firms in high trust countries is perceived as more credible by investors and thus elicits stronger reactions from them. We observe a very similar pattern from the path analysis results shown in Panel B where the market reaction measure is the abnormal trading volume (Abvol). That is, trust has both a significantly positive, direct effect on Abvol (coefficient: 0.256 , robust $t$-stat: 2.37 ) and a significantly positive, indirect effect on Abvol through Earnings quality (coefficient: 0.059, robust $t$-stat: 6.73). Collectively, the results from the path analysis suggest that trust affects investor reaction to earnings announcements not only indirectly through its effects on mediating variables such as reporting lag, analyst following, and earnings quality, but also directly through increasing the perceived credibility of reported earnings.

\subsection{Cross-country variations in the effect of trust on market reaction}

In this section, we first test $\mathrm{H} 2$ and examine whether the effect of trust on market reaction to earnings news varies with the strength of a country's formal institutions. We expect trust to play a more important role in countries characterized by weaker formal institutions such as poor investor protection and lax disclosure requirements, since there is greater uncertainty surrounding the corporate financial reporting in these countries accentuating the impact of trust. We estimate the regression model specified in equation (2) by focusing on investor protection and disclosure requirements as formal institutions. We 
create an indicator variable Low Investor Protection (or Low Disclosure Requirement) that is equal to one if a country's investor protection (or disclosure requirement) index is below the sample median. The results presented in columns (1) and (4) of Table 5 are based on investor protection while those in columns (2) and (5) are based on disclosure requirements. We find that regardless of which market reaction measure we use, the interaction terms between Trust and Low Investor Protection and between Trust and Low Disclosure Requirement both have significantly positive coefficients, suggesting that the positive effect of trust on investor reactions to earnings announcements is more pronounced in countries with poor investor protection or lax disclosure requirements. This is consistent with our expectation that trust serves as a substitute for a country's formal institutions and is a more important factor driving investor reaction to corporate financial disclosure in countries with weaker formal institutions.

We next examine $\mathrm{H} 3$ to see whether a country's average education level affects the relation between trust and investor reaction to earnings announcements. We estimate the regression specified in equation (3) and present the results in columns (3) and (6) of Table 5. While the coefficient on trust itself is not significant, the interaction term between Trust and the Low Education indicator has a significant and positive coefficient in both columns. This is consistent with the hypothesis that investors in countries with a lower average education level rely more on trust in responding to corporate earnings announcements.

\subsection{Cross-firm variations in the effect of trust on market reaction}

In this section, we test $\mathrm{H} 4$ and investigate whether the effect of trust on market reaction to earnings news displays any variations along the dimension of firm characteristics. Specifically, we hypothesize that trust has a more pronounced effect on investors' perception of firms' earnings information when firms are associated with greater information asymmetry. We construct three proxies for information asymmetry: (i) an indicator for firms operating in high-tech industries as defined by Loughran and Ritter (2004), (ii) an indicator for firms with positive R\&D expenditure, and (iii) an indicator for firms with above sample median market-to-book ratios. The regression model specified in 
equation (4) includes the information asymmetry proxies as well as their interaction terms with societal trust as additional explanatory variables. We estimate equation (4) and report the results in Table 6, with the first three columns based on abnormal return variance and the last three columns based on abnormal trading volume. We find that across all six specifications, the standalone term of societal trust continues to have a significantly positive effect on market reactions to earnings announcements and the interaction term between trust and the high information asymmetry indicator has a significant and positive coefficient. This is consistent with our conjecture that trust plays a more important role in driving investor reaction to earnings news when firms are associated with greater information asymmetry.

\subsection{Endogeneity correction}

A common concern for cross-country studies like ours is the "omitted variable" problem, since it is difficult to adequately control for all of the factors that can potentially influence the formation and accumulation of trust. If any of the uncontrolled or imperfectly controlled factors happens to be correlated with investor reactions to earnings announcements, the positive relation we document between trust and market reaction measures may simply be spurious. While this is always a possibility, we believe our results are unlikely to be completely driven by "omitted variables," since any such variable must be able to explain not only the main relation between trust and investor reactions to earnings news, but also the cross-sectional variations displayed by the relation along the dimension of country and firm characteristics (see Sections 4.4 and 4.5). For example, one potential alternative explanation for the positive relation between trust and investor reactions is that it is the stronger investor protection and more effectiveness legal enforcement that generate higher trust in a society as well as stronger investor reactions to earnings news. However, this explanation is unable to account for our evidence that the positive relation between trust and investor reactions is significantly more pronounced in countries with weaker formal institutions and it is also silent on why the relation between trust and investor reactions is more significant in countries with lower education levels. 
Despite the fact that the cross-sectional variation results are consistent with a causal interpretation that higher trust leads to stronger investor reactions to corporate earnings announcements, we more directly address the "omitted variable" problem and endogeneity concern by employing a two-stage least square (2SLS) regression framework. We use a country's primary religious adherence as an instrument for the level of societal trust, since as La Porta et al. (1997), Stulz and Williamson (2003), and Guiso, Sapienza, and Zingales $(2006,2008)$ point out, religious beliefs are more primitive than culture and can be considered exogenous. Guiso, Sapienza, and Zingales (2003) find that different religions have different effects on people's trust toward others, suggesting that religion satisfies the relevance requirement for instrumental variables. ${ }^{11} \mathrm{We}$ obtain information on a country's primary religion from Stulz and Williamson (2003) and the CIA Factbook 2003. There are six primary religions represented in our sample: Catholic, Protestant, Muslim, Buddhist, Judaism, and Hindu, as well as unidentified local beliefs for Hong Kong. We create seven indicator variables to represent these religious denominations and include six of them as instrumental variables in the first stage regression of the 2SLS, with Hindu being the excluded case.

We present the 2SLS regression results in Table 7. Column (1) reports the results from the first stage regression, where the dependent variable is the level of a country's societal trust. Consistent with prior evidence in the literature (Guiso, Sapienza, and Zingales (2003, 2006)), we find that in comparison to India where Hindu is the primary religion, trust is significantly higher in countries where the primary religion is Protestant or Buddhist and significantly lower in countries where the primary religion is Catholic, Muslim, or Judaism. It also appears that the local beliefs in Hong Kong display the highest positive correlation with trust, but we caution against over-interpreting this because of the unidentified nature of the beliefs and the concentration of the effect in one region. Overall, the significant coefficients

\footnotetext{
${ }^{11}$ Although we cannot test whether as an instrument religion satisfies the exclusion restriction, Callen, Morel, and Richardson (2011) find in a cross-country study that a country's religious adherence is not significantly related to proxies of earnings management. This evidence provides some assurance that religion satisfies the exclusion restriction.
} 
on the religion indicators suggest that our instruments indeed satisfy the relevance requirement. The partial adjust R-square attributed to our instruments is $13 \%$, statistically significant at less than $1 \%$ level.

With respect to other explanatory variables in the first stage model, we find that the disclosure requirement index has a significant and negative coefficient. This suggests a substitute relationship between a country's disclosure requirements and societal trust and is consistent with the prediction of Aghion et al. (2010) about trust and regulations at the country level. Though the investor protection index has a significantly positive coefficient, we find that once we break it into its two components, the antiself-dealing index and the law enforcement index, the anti-self-dealing index has a significantly negative coefficient while the law enforcement index has a significantly positive coefficient. The former finding is consistent with a substitutive relationship between regulations and trust, while the latter is consistent with more effective law enforcement fostering trust. ${ }^{12}$

Columns (2) and (3) report the second-stage regression results, with the dependent variable being abnormal return variance in column (2) and abnormal trading volume in column (3). In both columns, trust is the instrumented version of itself obtained from column (1). Consistent with the OLS results presented in Table 3, we find that societal trust continues to have significantly positive effects on both measures of investor reactions to corporate earnings announcements, suggesting that our findings are robust to correcting for the endogeneity of trust. ${ }^{13}$

\subsection{Construct validity of the measure of trust}

So far our analysis is based on a measure of trust of average citizens in a country. While this approach is consistent with much of the literature that examines how economic outcomes are related to trust and culture in general, ${ }^{14}$ one potential drawback is that the trust of average citizens may not

\footnotetext{
${ }^{12}$ We have no predictions about the coefficients on firm-level characteristics, which are included in the first stage as dictated by the econometrics of 2SLS regressions.

${ }^{13}$ In the robustness analysis presented in Section 4.8, we control for country fixed effects as an alternative way to address the omitted variable problem. Our results continue to hold.

${ }^{14}$ Examples of such studies the international context include Guiso, Sapienza, and Zingales (2009), Ahern, Daminielli, and Fracassi (2012), Giannetti and Yafeh (2012), Bottazzi, Da Rin, and Hellmann (2010), and Chui,
} 
accurately reflect the trust of the relevant economic decision makers. Specific to our context, the problem manifests in the form that the average citizens in a country may not be representative of the stock traders in that country, and therefore the trust of average citizens may not apply to the individuals who actually drive stock returns and trading volumes. ${ }^{15}$ This is ultimately an empirical question and is best addressed by constructing a measure of trust for stock traders in each country. However, we are not aware of any database that provides such information. As a result, we take three somewhat indirect approaches to alleviate this concern from a number of different angles.

\subsubsection{First approach}

In the first approach, we create an alternative trust measure based only on the responses of survey participates who are in the higher income groups of their respective countries. The logic behind this approach is that wealthier individuals are more likely to invest in the stock market (Guiso, Sapienza, and Zingales (2008) and therefore the trust measure constructed based on them should be more representative of the individuals who impact stock returns and trading volume. The WVS puts survey participants from each country into deciles based on their responses to an income-level related question. We construct two new trust measures, one based on individuals with above-country-median incomes (deciles 6 to 10) and the other based on individuals with top quintile incomes (deciles 9 and 10). We estimate our abnormal return variance and abnormal trading volume regressions against these two new trust measures along with control variables and present the results in Panel A of Table 8. We find that the new measures have significant and positive coefficients in both sets of regressions, reinforcing the evidence based on average citizens' trust.

\subsubsection{Second approach}

Titman, and Wei (2010), while examples in the domestic U.S. context include Hilary and Hui (2009), Kumar, Page, and Spalt (2012), and Shu, Sulaeman, and Yeung (2012). A notable exception is Guiso, Sapienza, and Zingales (2008), who relate the level of trust of individual Dutch households to their stock market participation decisions.

${ }^{15}$ We thank the referee for pointing this out. 
In this second approach, we examine the robustness of our findings in subsamples of countries with higher religious or ethnic homogeneity, since religion and ethnicity are two important determinants of trust (Guiso, Sapienza, and Zingales (2006)). Ceteris paribus, in religiously or ethnically more homogenous countries, individuals driving stock returns or trading volume are more likely to have the same religious or ethnic background as the average citizen and thus share the same level of trust. This helps validate the trust measure used in earlier tables.

We take the responses of WVS participants to the question about religious denomination and the question about ethnic group. We define a religious denomination or ethnic group as dominant if it accounts for at least $50 \%$ of the survey participants in a country. We then re-estimate the abnormal return variance and abnormal trading volume regressions in countries with a dominant religion or ethnicity, and present the results in Panel B of Table 8. We find that trust has a significant and positive coefficient in both regressions. In untabulated results, we find that our findings are robust to defining a dominant religion or ethnicity as one that accounts for $60 \%, 70 \%, 80 \%$, or $90 \%$ of the surveyed population in a country. We also compute the Herfindahl index of a country's religious or ethnicity concentration as an alternative way to define religious or ethnic homogeneity. We re-estimate our regressions in the subsample of countries with a Herfindahl index of religious or ethnic concentration that is above the sample median. We continue to find a positive and significant effect of trust on market reactions to corporate earnings announcements in these subsamples.

\subsubsection{Third approach}

As a third approach, we address the concern about the validity of our trust measure by exploring cross-country differences in the importance of institutional investors vs. individual investors and focusing on countries where institutional investors are less influential. ${ }^{16}$ The logic behind this approach is that stock investors in these countries are more likely to be similar to the average citizens. Ideally, we would like to have information on the breakdown of trading activities attributable to institutions and individuals

\footnotetext{
${ }^{16} \mathrm{We}$ thank the referee for this suggestion.
} 
in each given country and repeat our analysis in the subsample of countries where institutional investors are less important in driving stock returns and trading volumes. However, we do not know of any such measures or statistics for a large cross-section of countries as analyzed in our paper. Therefore, we proxy for the importance of institutional investors by institutional ownership. We use the global institutional ownership data from FactSet's LionShares database, which has previously been used in Ferreira and Matos (2008), Ferreira, Massa, and Matos (2010), and Aggarwal, Erel, Ferreira, and Matos (2011). ${ }^{17}$ This approach has the caveat that high institutional ownership does not necessarily translate into institutional investors accounting for more trading activities, especially if some of the institutional investments are long-term and passive in nature. With this drawback in mind, we carry out three additional sets of analysis.

First, we restrict our analysis to countries where foreign institutional investors play a less important role. The reason is that our trust measure may not be applicable to foreign institutional investors, who are likely to come from a different religious and cultural background from the domestic population. ${ }^{18}$ Following Ferreira and Matos (2008), Ferreira, Massa, and Matos (2010), and Aggarwal, Erel, Ferreira, and Matos (2011), we compute the aggregate percentage equity ownership held by foreign institutions for each country-year in our sample. We then focus on the subsample of country-years where the aggregate foreign institutional ownership is below sample median and re-estimate the abnormal return variance and trading volume regressions in this subsample. Results presented in Panel C of Table 8 below indicate that trust continues to have significant and positive coefficients in both regressions, and the magnitude of the coefficients is similar to that in Table 3.

Second, we exclude from our analysis countries where institutional investors, domestic and foreign, play a more important role. This is to directly address the concern that institutional investors in general may have different cultural values from average citizens whom the WVS data are better able to

\footnotetext{
${ }^{17}$ Since the LionShares data are available only from 1999, all our analyses using institutional ownership data are limited to firm-year observations from $1999 \mathrm{on}$. Since the Insider Trading dummy is equal to 1 for all countries after 1999, it is dropped as an explanatory variable in the regressions presented in Panels C, D, E, and G of Table 8.

${ }^{18}$ However, it is possible that foreign institutions hire local talent to make portfolio and trading decisions.
} 
describe. We compute the aggregate percentage equity ownership held by all institutional investors for each country year in our sample and re-estimate the abnormal return variance and trading volume regressions in the subsample of country years with below-sample-median aggregate institutional ownership. Panel D of Table 8 presents the regression results. We again find that social trust continues to have significant and positive coefficients in both regressions, indicating that even in countries where institutional investors play a less important role, trust still enhance investors' reactions to corporate earnings announcements.

Finally, since the unit of observations in our analysis is at the firm-year level, we also partition our sample based on whether a firm's aggregate institutional ownership in a given year is below the median of its corresponding country-year cohort. We again re-estimate the regressions of abnormal return variance and trading volume in the subsample of firms with below-median institutional ownership and present the results in Panel E of Table 8. We continue to find significant and positive coefficients on our measure of trust.

In summary, the results presented in this section suggest that the positive and significant effect of trust on market reactions to earnings announcements persists when we construct a trust measure based on individuals who are more likely to represent stock investors or when we focus on subsamples of countries or firms where the average citizen's trust is more reflective of the individuals who influence stock returns and trading volumes.

\subsubsection{Reexamining the interaction effect of trust and education}

Analogous to the concern about the construct validity of our trust measure, a country's average education level may not represent that of individuals driving stock returns and trading volume. This could make it problematic for us to conclude that less educated investors rely more on trust in analyzing and reacting to corporate earnings announcements. We address this concern in two ways.

First, to the extent that higher-income individuals are more likely to represent stock traders that drive stock returns and trading volume, we interact the trust measure based on higher-income individuals 
with the average education level of higher-income individuals. Specifically, we take the average of the highest education level achieved by higher-income individuals in each country, ${ }^{19}$ and redefine the Low Education dummy as an indicator variable equal to one if the average education level of a country's higher-income individuals is below the median of all countries. The results presented in Panel F of Table 8 show that the interaction term between Trust and Low Education (both defined based on higher-income individuals) has a significantly positive coefficient in both abnormal return variance and abnormal trading volume regressions. This evidence provides additional support for the hypothesis that investors with less education rely more on trust in reacting to corporate earnings announcements.

Second, we continue to use the level of trust and education of a country's average citizens, but we re-estimate the interaction effect of trust and education in the subsample of firms where institutional investors are less important. Specifically, we focus on the subsample of firms whose total institutional ownership is below the median of their country-year cohort, with the underlying assumption that investors in these firms are similar to the average citizens in their respective countries in terms of both trust and education levels. Panel G of Table 8 presents the regression results. We find that the positive effect of trust on market reaction measures is significantly stronger in countries with a lower average education level, which reinforces the full-sample results presented in Table 5.

\subsection{Robustness tests}

Our results are robust to a battery of sensitivity analyses. We start by augmenting regression equation (1) with additional controls. Specifically, we first control for several country-level variables including a country's legal origin (an indicator variable for common law countries), stock market

\footnotetext{
${ }^{19}$ Question X025 in WVS relates to the highest education level attained by an individual. Survey participants are asked to choose from the following categories: 1 for incomplete elementary education, 2 for complete (compulsory) elementary education, 3 for incomplete secondary school (technical/vocational type/(compulsory) elementary education and basic vocational qualification), 4 for complete secondary school (technical/vocational type/secondary, intermediate vocational qualification), 5 for incomplete secondary school (university-preparatory type/secondary, intermediate general qualification), 6 for complete secondary school (university-preparatory type/full secondary, maturity level certificate), 7 for some university without degree/higher education - lower-level tertiary certificate, and 8 for university with degree/higher education - upper-level tertiary certificate.
} 
development (measured as the total market capitalization divided by GDP), and two earning quality measures (the earnings management index from Leuz et al. (2003) and the CIFAR index of transparency from La Porta et al. (1998)). By controlling for a country's stock market development, we can address a potential alternative explanation for our finding, i.e., the stock market tends to be more developed and more efficient in more trusting countries, and as a result, earnings announcements generate stronger market reaction since information is impounded into stock prices more quickly. Similarly, controlling for earnings quality measures allows us to examine whether trust enhances investor reactions to earnings announcement only indirectly by improving earnings quality or whether trust has a direct impact on investor reactions by affecting how investors perceive the information contained in earnings announcements. However, there is also an important caveat in controlling for these country-level characteristics. That is, these variables are endogenous and, more critically, have been shown to be driven by trust, investor protection, and disclosure requirements (Leuz, Nanda, and Wysocki (2003) and Guiso, Sapienza, and Zingales $(2004,2008))$. Therefore, including them as explanatory variable at best may absorb the effects of the more fundamental variables and at worst may even bias the coefficient estimates of other independent variables.

With this caveat in mind, we present the regression results in columns (1) and (5) of Panel A of Table 9. We find that stock market development has an insignificant, albeit sometimes positive, effect on measures of investor reactions, providing some mild evidence that more developed stock markets react to earnings announcements more vigorously. We also find that both measures of earnings quality have significantly positive coefficients, consistent with the notion that announcements of higher quality earnings generate stronger investor reaction. More importantly, despite these additional controls, social trust continues to have a significant and positive effect on investor reactions, suggesting that our results are not just driven by more trusting countries having more developed stock markets or having higherquality earnings.

In columns (2) and (6) of Panel A of Table 9, we control for other dimensions of culture such as hierarchy and individualism constructed using WVS responses (as defined earlier). The measures of 
hierarchy and individualism are not available for some countries such as U.K., reducing the number of observations to 47,360 . There does not appear to be a clear pattern of association between hierarchy and individualism and investor reaction to earnings announcements. Hierarchy has positive coefficients in columns (2) when the market reaction measure is abnormal return variance but negative coefficients in column (4) when the dependent variable is abnormal trading volume. The coefficients on individualism are not significant in column (2) and (4). However, more important for our purpose, we find that societal trust continues to significantly enhance investor reaction to earnings announcements.

In columns (3) and (7) of Panel A of Table 9, we control for the four cultural indexes constructed by Hofstede (1980) to capture individualism, power distance, uncertainty avoidance, and masculinity in the abnormal return variance and trading volume regressions. The results show that our measure of trust continues to have a significant and positive coefficient in both regressions, suggesting that the effect of trust on market reactions to earnings announcements is incremental to any effect of Hofstede's cultural measures. Also worth noting is that abnormal return variance and trading volume around earnings announcements are significantly higher in countries with higher individualism. This is in line with the Chui, Titman, and Wei's (2010) finding of higher monthly trading volume and return volatility in countries with higher individualism. ${ }^{20}$

In columns (4) and (8) of Panel A of Table 9, we control for country fixed effects in place of the country-specific characteristics as included in previous regressions. We find that trust continues to have significant and positive effects on our two measures of market reactions to corporate earnings announcements. This evidence provides further support for our hypothesis that a higher level of social trust increases the perceived credibility of corporate financial disclosure and leads to stronger investor reactions to earnings announcements.

We next check the robustness of our results to two different measures of trust. This is in addition to the set of analysis presented in Section 4.7 regarding the construct validity of our trust measure.

\footnotetext{
${ }^{20}$ Chui, Titman, and Wei (2010) examine monthly trading volume and return volatility, while we focus on abnormal return variance and trading volume around earnings announcements that are above the normal levels.
} 
Specifically, we re-estimate equation (1) using an alternative definition of societal trust, namely a trust index calculated for each country based on the following formula: $100+(\%$ of participants who respond “most people can be trusted") - (\% of participants who respond "can't be too careful"). Unlike the trust measure used in our earlier analyses, this index is time invariant. ${ }^{21}$ Results presented in Panel B of Table 9 show that this alternative definition of trust is also significantly and positively related to both market reaction measures. We also follow Guiso, Sapienza, and Zingales (2008) and Aghion et al. (2010) in replacing the generalized trust measure we currently use with a measure of trust specifically toward major corporations. ${ }^{22}$ Results in Panel $\mathrm{C}$ of Table 9 show that this more specific measure of trust has a significantly positive effect on investor reactions to earnings announcements, regardless of whether we measure investor reactions by abnormal return variance or abnormal trading volume.

In Panel D of Table 9, we examine whether our results are sensitive to our definition of the earnings announcement event window. We repeat our analysis using three alternative event windows: (-1, $+1),(0,+2)$ and $(-2,+2)$, and the effect of trust on investor reactions to earnings announcement remains significantly positive for all event windows we consider.

Given the disproportionally large representation in the firm-year observation sample by firms from the US, UK, and Japan, we address the concern of whether our results are primarily driven by one of these countries. First, we re-estimate our baseline regression model (equation (1)) at the aggregate country level, where we take the annual country average of each variable in the model. We only retain countries with at least thirty observations in a given year in this analysis, resulting in a sample of 191 country-year observations. Panel E of Table 9 presents the regression results. We find that despite the much smaller sample size, societal trust continues to have a significant and positive effect on both abnormal return variance (column (1)) and abnormal trading volume (column (2)), reinforcing the evidence from the firm-

\footnotetext{
${ }^{21}$ It is available for download from www.worldvaluessurvey.org.

${ }^{22}$ The measure of trust toward corporations is based on the following WVS question: "Do you have a lot of confidence, quite a lot of confidence, not very much confidence, no confidence at all in the following: Major companies?..." The answers range from 1 for a lot of confidence, through 2 for quite a lot of confidence, 3 for a little confidence, and 4 for no confidence. We create an indicator variable capturing trust in corporations that is equal to 0 if the respondent chooses the answer no confidence and 1 otherwise. We then take the average of the responses in each country year.
} 
year analysis in Table 3. This country aggregate analysis suggests that our findings are unlikely to be driven by countries with disproportionately large representations in the firm-year observation sample (e.g., US, Japan, and UK), since the country aggregate analysis treats each country-year as one observations regardless how many firms a country has in a given year.

We then re-estimate our model (1) excluding Japan, UK, or US, one country at a time and then altogether, and report the results in Panel F of Table 9. Social trust continues to have a consistently significant effect on market reaction measures, despite the absence of any or all of the three countries, indicating that our results are not driven by one particular country or just these three countries. ${ }^{23}$

Finally, following DeFond et al. (2007) and Landsman et al. (2012), we examine whether our results are robust to using the logarithmic or rank transformation of abnormal return variance and abnormal trading volume. This is to address the concern that the original ratio-based constructs of abnormal return variance and trading volume are prone to having extreme values and skewed distributions. Results presented in Panel G of Table 9 indicate that social trust continues to have significant and positive effects on abnormal return variance and trading volume, even when we use their logarithmic or rank transformations as the dependent variables. ${ }^{24}$

\footnotetext{
${ }^{23}$ We would like to point out that in Panel F of Table 9, the coefficient estimates on two control variables, the investor protection index and the quarterly reporting dummy, switch sign when we drop UK observations from our sample. UK is an interesting country, in the sense that it has the highest investor protection index in our sample, it does not require quarterly reporting by firms, and its firms have the highest average abnormal return variance and the $3^{\text {rd }}$ highest average abnormal trading volume around earnings announcements across all countries in our sample (see Panel B of Table 2). Therefore, UK's presence in our sample is likely to contribute greatly to the patterns reported in Table 3 that abnormal return variance and trading volume have significantly positive relations with investor protection and significantly negative relations with quarterly reporting. It appears that UK may be so important that removing it from our sample weakens those relations to such a large extent that they even change sign. In light of the outsized influence of UK, we examine whether this result is driven by outliers or extreme values in UK observations. However, the result persists when we winsorize the dependent variables or replace the ratio measures of dependent variables with their log or rank transformations. While we do not have a complete explanation for why the coefficient estimates on investor protection and quarterly reporting switch sign when we drop UK, we do find that these coefficients are also affected by what other countries are excluded from the analysis. For example, in columns (4) and (8) of Panel F of Table 9, when we remove US and Japan in addition to UK from our sample, abnormal return variance and trading volume are back to being positively related to investor protection and negatively related to quarterly reporting, even though the relations are only statistically significance for abnormal return variance. While further exploration is clearly warranted on how abnormal return variance and trading volume around earnings announcements are related to investor protection and quarterly reporting, we feel that it is outside the scope of the current paper.

${ }^{24}$ Our results are robust to ranking abnormal return variance and trading volume in the entire sample or ranking within each year. The results presented in Panel G are based on ranking within each year.
} 


\section{Conclusion}

In this paper, we examine whether national culture affects investors' perception and utilization of financial disclosure by firms. Specifically, we examine the effect of societal trust on investor reactions to corporate earnings announcements. We explore two competing hypotheses. On the one hand, societal trust mitigates outside investors' concern of moral hazard and reduces the value of corporate earnings announcements to them, thereby weakening their reactions to these events. On the other hand, investors in more trusting countries perceive firms' financial disclosure as more credible and therefore respond in a more vigorous fashion to corporate earnings announcements. We analyze the abnormal trading volume and abnormal stock return variance during the earnings announcement period in a large sample of firmyear observations across 25 countries, and find that both measures of investor reactions to earnings announcements are significantly higher in more trusting countries. These results are robust to controlling for a multitude of country-level characteristics including legal origin, investor protection, disclosure requirements and earnings quality as well as many other dimensions of culture.

In additional analysis, we find significant evidence that the positive effect of societal trust on investor reactions to earnings news is more pronounced when a country's investor protection and disclosure requirements are weaker, when a country's average education level is lower, and when firm level information asymmetry is higher. These cross-sectional variations are consistent with prior theory and evidence in the literature that trust and formal institutions are substitutes, less educated people rely more on trust in making economic decisions, and trust plays a more important role in poor information environments. Collectively, they point to a causal interpretation of our results that trust affects investors' perception of corporate financial reporting and enhances their reaction to earnings announcements. Evidence from 2SLS regression where we instrument social trust by a country's primary religion lends further support to this interpretation.

Overall, our investigation provides first evidence highlighting societal trust as a new factor that can help explain cross-country variations in investors' reaction to corporate earnings announcements. As 
such, we demonstrate that the capital market's reaction to corporate financial disclosure is impacted by not only formal institutions at the country level but also informal ones such as national culture and in particular social trust. Our findings have important implications for the determinants of capital market efficiency and informativeness of corporate financial reporting. 


\section{References}

Aggarwal, R., I. Erel, M. Ferreira, and P. Matos, 2011. Does governance travel around the world?

Evidence from institutional investors. Journal of Financial Economics, 100, 154-181.

Agnion, P., Y. Algan, P. Cahuc, and A. Shleifer, 2010. Regulation and distrust. Quarterly Journal of Economics 125, 1015-1049.

Ahern, K., D. Daminielli, and C. Fracassi, 2012. Lost in translation? The effect of cultural values on mergers around the world. Journal of Financial Economics forthcoming.

Alford, A., J. Jones, R. Leftwich, and M. Zmijewski, 1993. The relative informativeness of accounting disclosures in different countries. Journal of Accounting Research 31, 183-223.

Ali, A. and L. Hwang, 2000. Country-specific factors related to financial reporting and the value relevance of accounting data. Journal of Accounting Research 38, 1-21.

Atiase, R., L. Bamber, and S. Tse, 1989. Timeliness of financial reporting, the firm size effect, and stock price reactions to annual earnings announcements. Contemporary Accounting Research 5, 526-552.

Bailey, W., A. Karolyi, and C. Salva, 2006. The economic consequences of increased disclosure: Evidence from international cross-listings. Journal of Financial Economics 81, 175-213.

Balsam, S., J. Krishan and J. Yang, 2003. Auditor industry specialization and earnings quality. Auditing: Journal of Practice and Theory 22, 71-97

Bamber, L., T. Christensen, and K. Gaver, 2000. Do we really 'know' what we think we know? A case study of seminal research and its subsequent overgeneralization. Accounting, Organization and Society $25,103-129$.

Barber, B., E. De George, R. Lehavy, and B. Trueman, 2012. The earnings announcement premium around the globe. Journal of Financial Economics, forthcoming.

Beaver, W., 1968. Information content of annual earnings announcements. Journal of Accounting Research 6, 67-92.

Bhattacharya, U. and H. Daouk, 2002. The world price of insider trading. Journal of Finance 57, 75-108.

Bottazi, L., M. Da Rin, and T. Hellman, 2011. The importance of trust for investment: evidence from venture capital. Working Paper. NBER.

Bushman, R., J. Piotroski, and A. Smith, 2004. What determines corporate transparency? Journal of Accounting Research 42, 207-252.

Callen, J., M. Morel and G. Richardson, 2011. Do culture and religion mitigate earnings management? Evidence from a cross-country analysis. International Journal of Disclosure and Governance 8, 103-121.

Carlin, B., F. Dorobantu, and S. Visvanathan, 2009. Public trust, the law and financial investment. Journal of Financial Economics 92, 321-341. 
Chambers, A. and S. Penman, 1984. Timeliness of reporting and stock price reaction to earnings announcements. Journal of Accounting Research 22, 21-47.

Christensen, T., T. Smith, and P. Stuerke, 2004. Public predisclosure information, firm size, analyst following, and market reactions to earnings announcements. Journal of Business, Finance, and Accounting 31, 951-984.

Chui, A., S. Titman, and K. Wei, 2010. Individualism and momentum around the world. Journal of Finance 65, 361-392.

CIA Factbook, 2003. Available at: https://www.cia.gov/index.html.

Coval, J. and T. Moskowitz, 1999. Home bias at home: local equity preference in domestic portfolios. Journal of Finance 54, 2045-2073.

DeFond, M., M. Hung, and R. Trezevant, 2007. Investor protection and the information content of annual earnings announcements: International evidence. Journal of Accounting and Economics 43, 37-67

Defond, M., X. Hu, M. Hung, and S. Li, 2011. The impact of mandatory IFRS adoption on foreign mutual fund ownership: the role of comparability. Journal of Accounting and Economics 51, 240-258.

Diamond D. and R. Verrecchia, 1991. Disclosure, liquidity, and the cost of capital. Journal of Finance 46, $1325-1359$.

Djankov, S., R. La Porta, F. Lopez-de-Silanes, and A. Shleifer, 2008. The law and economics of selfdealing. Journal of Financial Economics 88, 430-465.

Duarte, J., S. Siegel, and L. Young, 2010. Trust and credit. Working Paper. Rice University.

Ferreira, M. and P. Matos, 2008. The colors of investors' money: the role of institutional investors around the world. Journal of Financial Economics, 88, 499-533.

Ferreira, M., M. Massa, and P. Matos, 2010. Shareholders at the gate? institutional investors and crossborder mergers and acquisitions. Review of Financial Studies 23, 601-644.

French, K. and J. Poterba, 1991. Investor diversification and international equity markets. American Economic Review 82, 222-226.

Fukuyama, F., 1995. Trust: Social virtues and the creation of prosperity. NY: Free Press.

Gambetta, D., 1988. Can we trust trust? Trust: Making and breaking cooperative relations, 213-237. New York: Blackwell.

Giannetti, M. and Y. Yafeh, 2012. Do cultural differences between contracting parties matter? Evidence from syndicated bank loans. Management Science 58, 365-383.

Glaeser, E., D. Laibson, and B. Sacerdote, 2002. An economic approach to social capital. Economic Journal 112, 437-458.

Griffin, J., N. Hirschey, and P. Kelly, 2011. Why does the reaction to news announcements vary across countries? Review of Financial Studies 24, 3941-3992. 
Guiso, L., P. Sapienza, and L. Zingales, 2003. People's opium? Religion and economic attitudes. Journal of Monetary Economics 50, 225-282.

Guiso, L., P. Sapienza, and L. Zingales, 2004. The Role of social capital in financial development. American Economic Review 94, 526-556.

Guiso, L., P. Sapienza, and L. Zingales, 2006. Does culture affect economic outcomes? Journal of Economic Perspectives 20, 23-48.

Guiso, L., P. Sapienza, and L. Zingales, 2008. Social capital as good culture. Journal of the European Economic Association 6, 295-320.

Guiso, L., P. Sapienza, and L. Zingales, 2008. Trusting the stock market. Journal of Finance 63, 25572600.

Guiso, L., P. Sapienza, and L. Zingales, 2009. Cultural biases in economic exchange. Quarterly Journal of Economics 124, 1095-1131.

Guiso, L., P. Sapienza, and L. Zingales, 2010. Civic capital as the missing link. Handbook of Social Economics, Volume 1A.

Harris, M., and A. Raviv, 1993. Differences of opinion make a horse race. Review of Financial Studies 6, 473-506.

Hilary, G. and K. Hui, 2009. Does religion matter in corporate decision making in America? Journal of Financial Economics 93, 455-473.

Hofstede, G., 1980. Culture's consequences: International differences in work-related values (Sage Publication, Beverly Hills, CA).

Hung, M., 2000. Accounting standards and value relevance of financial statements: An international analysis. Journal of Accounting and Economics 30, 401-420.

Jensen, M. and W. Meckling, 1976. Theory of the firm: managerial behavior, agency costs, and ownership structure. Journal of Financial Economics 3, 305-360.

Kandel, E. and N. Pearson, 1995. Differential interpretation of information and trade in speculative markets. Journal of Political Economy 103, 831-872.

Kaufmann, D., A. Kraay, and M. Mastruzzi, 2003. Government matters III: Governance indicators for 1996-2002. World Bank Working Paper.

Kim, O. and R. Verrecchia, 1991a. Trading volume and price reactions to public announcements. Journal of Accounting Research 29, 302-321.

Kim, O. and R. Verrecchia, 1991b. Market reaction to anticipated announcements. Journal of Financial Economics 30, 273-309.

Kim, O. and R. Verrecchia, 1994. Market liquidity and volume around earnings announcements. Journal of Accounting and Economics 17, 41-67. 
Knack, S. and P. Keefer, 1997. Does social capital have an economic payoff? A Cross-Country Investigation. Quarterly Journal of Economics 112, 1251-1288.

Kumar, A., J. Page, and O. Spalt, 2011. Religious beliefs, gambling attitudes, and financial market outcomes. Journal of Financial Economics 102, 671-708.

La Porta, R., F. Lopez-De-Silanes, A. Shleifer, and R. Vishny, 1997. Trust in large organizations. American Economic Review 87, 333-338.

La Porta, R., F. Lopez-De-Silanes, A. Shleifer, and R. Vishny, 1998. Law and Finance. Journal of Political Economy 106, 1114-1155.

La Porta, R., F. Lopez-de-Silanes, and A. Shleifer, 2006. What works in securities laws? Journal of Finance 61, 1-33.

Landsman, W. and E. Maydew, 2002. Has the information content of quarterly earnings announcements declined in the past three decades? Journal of Accounting Research 40, 797-808.

Landsman, W., E. Maydew, and J. Thorncock, 2012. The information content of annual earnings announcements and mandatory adoption of IFRS. Journal of Accounting and Economics 53, 34-54.

Lang, M., K. Lins, and M. Maffet, 2012. Transparency, liquidity, and valuation: international evidence on when transparency matters most. Journal of Accounting Research 50, 729-774.

Leuz, C., V. Nanda, and P. Wysocki, 2003. Earnings management and investor protection: an international comparison. Journal of Financial Economics 69, 505-527.

Loughran, T., and J. Ritter, 2004. Why has IPO underpricing changed over time? Financial Management $33,5-37$.

Myers, S. and N. Majluf, 1984. Corporate financing and investment decisions when firms have information that investors do not have. Journal of Financial Economics 13, 197-221.

Petersen, M., 2009. Estimating standard errors in finance panel data sets: comparing approaches. Review of Financial Studies 22, 435-480.

Piotroski, J. and D. Roulstone, 2004. The influence of analysts, institutional investors, and insiders on the incorporation of market, industry, and firm-specific information into stock prices. The Accounting Review 79, 1119-1151.

Putnam, R., 1993. Making Democracy Work: Civic Traditions in Modern Italy. Princeton, N.J., Princeton University Press.

Rogers, J. and P. Stocken, 2005. Credibility of management forecasts. The Accounting Review 80, 12331260.

Shu, T., J. Sulaeman, and P. Yeung, 2012. Local religious beliefs and mutual fund risk-taking behaviors. Management Science forthcoming.

Stulz, R. and R. Williamson, 2003. Culture, openness, and finance. Journal of Financial Economics 70, 303-339. 
Sobel, M., 1982. Asymptotic confidence intervals for indirect effects in structural equation models. Sociological Methodology 13, 290-312.

Teoh, S. and T. Wong, 1993. Perceived auditor quality and the earnings response coefficient. The Accounting Review 68, 346-366.

Williamson, O., 1993. Calculativeness, trust, and economic organization. Journal of Law and Economics $36,453-486$.

Wright, S., 1934. The method of path coefficients. Annals of Mathematical Statistics 5, 161-215.

Zak, P. and S. Knack, 2001. Trust and Growth. Economic Journal 111, 295-321. 


\section{Appendix: Variable Definitions}

\begin{tabular}{|c|c|}
\hline Variable & Definition \\
\hline $\begin{array}{l}\text { Abnormal Return Variance } \\
\text { (abvar) }\end{array}$ & $\begin{array}{l}\text { Stock return variance over the event window, scaled by the stock return variance } \\
\text { over the estimation window. Stock return variance over the event window equals } \\
\text { the average of the squared prediction errors from the market model during the } \\
\text { firm's earnings announcement window }(0,+1) \text {, with day } 0 \text { being the earnings } \\
\text { announcement date reported in IBES. The stock return variance over the } \\
\text { estimation window equals the variance of the residual returns from the firms' } \\
\text { market model estimated over the estimation window }(-120,-21) \text {. }\end{array}$ \\
\hline $\begin{array}{l}\text { Abnormal Trading Volume } \\
\text { (abvol) }\end{array}$ & $\begin{array}{l}\text { The average trading volume over the event window, scaled by the average } \\
\text { trading volume over the estimation window }(-120,-21) \text {. }\end{array}$ \\
\hline Societal Trust & $\begin{array}{l}\text { Based on responses to the WVS question: "Generally speaking, would you say } \\
\text { that most people can be trusted or that you need to be very careful in dealing } \\
\text { with people?" We recode the response to this question to } 1 \text { if a survey participant } \\
\text { reports that most people can be trusted and } 0 \text { otherwise and then calculate the } \\
\text { mean of the response in each country year. Higher index values correspond to } \\
\text { higher trust. }\end{array}$ \\
\hline Hierarchy & $\begin{array}{l}\text { Based on responses to the WVS question: People have different ideas about } \\
\text { following instructions at work. Some say that one should follow one's superior's } \\
\text { instructions even when one does not fully agree with them. Others say that one } \\
\text { should follow one's superior's instructions only when one is convinced that they } \\
\text { are right. With which of these two opinions do you agree? } \\
\text { 1. Should follow instructions } \\
\text { 2. Must be convinced first } \\
\text { We recode the response to the above question to } 1 \text { if a survey participant agrees } \\
\text { with the first opinion and } 0 \text { otherwise, and then take the average of the response } \\
\text { in each country year. Higher index values correspond to greater hierarchy. }\end{array}$ \\
\hline Individualism & $\begin{array}{l}\text { Based on responses to the WVS question: How would you place your views on } \\
\text { this scale? I means you completely agree with the statement on the left; } 10 \text { means } \\
\text { you agree completely with the statement on the right; and if your views fall } \\
\text { somewhere in between, you can choose any number in between. } \\
\text { 1. Incomes should be made more equal } \\
\text { 2. We need larger income differences as incentives for individual effort } \\
\text { We rescale the response of each survey participant to this question to be between } \\
0 \text { and } 1 \text { with } 0 \text { representing completely agreeing with the first statement and } 1 \\
\text { representing completely agreeing with the second statement, and then take the } \\
\text { average of the response in each country year. Higher index values correspond to } \\
\text { more individualism. }\end{array}$ \\
\hline Investor Protection & $\begin{array}{l}\text { Sum of the anti-self-dealing index from Djankov et al. (2006) and the law } \\
\text { enforcement index from Kaufmann, Kraay, and Mastruzzi (2003) after both } \\
\text { indices are rescaled to be between } 0 \text { and } 1 \text {. }\end{array}$ \\
\hline Disclosure Requirement & $\begin{array}{l}\text { This index is from La Porta et al. (2006) and captures (1) a country's requirement } \\
\text { (or the lack thereof) of the delivery of a prospectus to potential investors in } \\
\text { advance of securities issuance, and the extent of affirmative disclosure } \\
\text { requirements in the following five areas: (2) insiders' compensation; (3) } \\
\text { ownership by large shareholders; (4) inside ownership; (5) contracts outside the } \\
\text { normal course of business; and (6) transactions with related parties. }\end{array}$ \\
\hline Insider Trading & $\begin{array}{l}\text { An indicator variable that is equal to one in the years after the first legal case is } \\
\text { brought against insider trading, and zero otherwise. }\end{array}$ \\
\hline Firm Size & $\begin{array}{l}\text { Logarithmic transformation of the market value of equity in thousands of US } \\
\text { dollars. }\end{array}$ \\
\hline |UE & $\begin{array}{l}\text { Magnitude of unexpected earnings. Unexpected earnings equal actual annual } \\
\text { earnings minus the most recent mean forecasted annual earnings, scaled by the } \\
\text { most recent stock price. }\end{array}$ \\
\hline
\end{tabular}




\begin{tabular}{|c|c|}
\hline Firm leverage & Firm total liabilities divided by total assets. \\
\hline Quarterly Reporting & $\begin{array}{l}\text { An indicator variable equal to one if the firm has quarterly reporting, and zero } \\
\text { otherwise. }\end{array}$ \\
\hline Reporting Lag & $\begin{array}{l}\text { The number of days from the fiscal year end to the earnings announcement date } \\
\text { reported by IBES. }\end{array}$ \\
\hline Largest 20 & $\begin{array}{l}\text { An indicator variable equal to one if the firm is one of the largest } 20 \text { firms in its } \\
\text { country. }\end{array}$ \\
\hline Cross Listing & $\begin{array}{l}\text { An indicator variable equal to one if the securities belong to foreign firms cross- } \\
\text { listed in the US. }\end{array}$ \\
\hline Forecast Dispersion & $\begin{array}{l}\text { Standard deviation of the analysts' earnings forecasts scaled by the most recent } \\
\text { stock price. }\end{array}$ \\
\hline Forecast Number & The number of annual earnings forecasts reported by IBES. \\
\hline Loss Dummy & $\begin{array}{l}\text { An indicator variable equal to one if the IBES reported actual earnings are less } \\
\text { than zero. }\end{array}$ \\
\hline Low Investor Protection & $\begin{array}{l}\text { An indicator variable equal to one if a firm's investor protection index is below } \\
\text { sample median. }\end{array}$ \\
\hline Low Disclosure Requirement & $\begin{array}{l}\text { An indicator variable equal to one if a firm's disclosure requirement index is } \\
\text { below sample median. }\end{array}$ \\
\hline Low Education & $\begin{array}{l}\text { An indicator variable equal to one if a country's average education level } \\
\text { measured by years of schooling among people older than } 15 \text { years is below } \\
\text { sample median. The data is obtained from World Bank website } \\
\text { (http://www.worldbank.org/). The data is available every } 5 \text { years. We use the } \\
\text { data of } 1995 \text {, the beginning of our sample period. }\end{array}$ \\
\hline High Information Asymmetry & $\begin{array}{l}\text { An indicator variable equal to one if a firm is in a high tech industry, where high } \\
\text { tech industry is defined following Loughran and Ritter (2004), if a firm has } \\
\text { positive R\&D, or if a firm's market-to-book ratio is higher than the sample } \\
\text { median in a given country year. }\end{array}$ \\
\hline $\begin{array}{l}\text { Catholic, Protestant, Muslim, } \\
\text { Buddhist, Judaism, Hindu, and } \\
\text { Indigenous }\end{array}$ & $\begin{array}{l}\text { Catholic, Protestant, Muslim, Buddhist, Judaism, and Hindu are indicator } \\
\text { variables capturing whether a country's primary religious belief is one of these } \\
\text { six religions. Indigenous is an indicator variable capturing Hong Kong's local } \\
\text { religious belief. The data is obtained from Stulz and Williamson (2003) and the } \\
\text { CIA Factbook } 2003 \text {. }\end{array}$ \\
\hline Hofstede Culture Indexes & $\begin{array}{l}\text { Four Hofstede culture indexes capturing individualism, power distance, } \\
\text { uncertainty avoidance, and masculinity. }\end{array}$ \\
\hline Societal Trust (Alternative 1) & $\begin{array}{l}\text { Trust index calculated for each country as: } 100+(\% \text { Most people can be } \\
\text { trusted) }-(\% \text { Can't be too careful), the index is time invariant and downloaded } \\
\text { from the website: www.worldvaluessurvey.org. }\end{array}$ \\
\hline Societal Trust (Alternative 2) & $\begin{array}{l}\text { Country-year average of rescaled responses to the following WVS question: "Do } \\
\text { you have a lot of confidence, quite a lot of confidence, not very much confidence, } \\
\text { no confidence at all in the following: Major companies?..." Higher index values } \\
\text { correspond to higher trust. }\end{array}$ \\
\hline Common Law Origin & $\begin{array}{l}\text { An indicator variable equal to one if a country is a common law country and zero } \\
\text { otherwise. }\end{array}$ \\
\hline Stock Market Development & Stock market development, measured as market capitalization divided by GDP. \\
\hline Earnings Quality Index & $\begin{array}{l}\text { The aggregate earnings management score from Leuz et al. (2003) multiplied by } \\
-1 \text {. The score, based on data over the } 1990 \text { to } 1999 \text { period, equals the average } \\
\text { rank of two earnings-smoothing measures and two earnings-discretion measures. }\end{array}$ \\
\hline CIFAR Index & $\begin{array}{l}\text { Counts of inclusion of } 90 \text { items in corporate annual reports by firms in a country, } \\
\text { from Bushman, Piotroski, and Smith (2004). }\end{array}$ \\
\hline
\end{tabular}


Table 1. Sample distribution by year and country

This table summarizes annual and country distributions of firm-year observations and some main variables in our sample. All variables are defined in the Appendix.

\begin{tabular}{|c|c|c|c|c|c|c|c|}
\hline \multicolumn{8}{|c|}{ Panel A: Annual distribution } \\
\hline Year & $\mathrm{N}$ & Year & $\mathrm{N}$ & Year & $\mathrm{N}$ & Year & $\mathrm{N}$ \\
\hline 1995 & 2,062 & 1999 & 3,579 & 2003 & 3,669 & 2007 & 5,422 \\
\hline 1996 & 2,697 & 2000 & 3,732 & 2004 & 3,808 & 2008 & 5,210 \\
\hline 1997 & 3,075 & 2001 & 3,578 & 2005 & 4,403 & Total & 53,362 \\
\hline 1998 & 3,505 & 2002 & 3,598 & 2006 & 5,024 & & \\
\hline \multicolumn{8}{|c|}{ Panel B: Country distribution } \\
\hline Country & $\mathrm{N}$ & & $\begin{array}{l}\text { Abnormal } \\
\text { Return } \\
\text { Variance }\end{array}$ & $\begin{array}{c}\text { Abnormal } \\
\text { Trading } \\
\text { Volume }\end{array}$ & Societal trust & & $\begin{array}{l}\text { Investor } \\
\text { Protection }\end{array}$ \\
\hline Argentina & 131 & & 1.504 & 1.135 & 0.176 & & 0.920 \\
\hline Australia & 2,219 & & 3.375 & 1.605 & 0.436 & & 1.587 \\
\hline Canada & 2,479 & & 2.944 & 1.704 & 0.393 & & 1.587 \\
\hline Finland & 762 & & 3.843 & 2.183 & 0.529 & & 1.583 \\
\hline France & 556 & & 4.239 & 2.023 & 0.187 & & 1.330 \\
\hline Germany & 1,308 & & 2.214 & 1.385 & 0.336 & & 1.247 \\
\hline Hong Kong & 400 & & 4.020 & 1.992 & 0.411 & & 0.833 \\
\hline India & 854 & & 2.168 & 1.569 & 0.332 & & 1.503 \\
\hline Indonesia & 173 & & 1.772 & 1.399 & 0.475 & & 1.167 \\
\hline Israel & 143 & & 2.926 & 1.732 & 0.235 & & 1.497 \\
\hline Italy & 456 & & 2.915 & 1.715 & 0.292 & & 1.087 \\
\hline Japan & 6,717 & & 2.616 & 1.505 & 0.416 & & 1.413 \\
\hline Malaysia & 305 & & 1.911 & 1.530 & 0.088 & & 1.503 \\
\hline Netherlands & 223 & & 4.731 & 1.953 & 0.445 & & 1.500 \\
\hline New Zealand & 306 & & 2.719 & 1.471 & 0.502 & & 1.587 \\
\hline Philippines & 198 & & 2.408 & 1.390 & 0.118 & & 0.920 \\
\hline Singapore & 469 & & 3.269 & 1.903 & 0.147 & & 1.663 \\
\hline South Africa & 642 & & 1.460 & 1.229 & 0.153 & & 1.253 \\
\hline Spain & 762 & & 1.802 & 1.325 & 0.300 & & 1.663 \\
\hline Sweden & 987 & & 4.054 & 2.113 & 0.657 & & 1.583 \\
\hline Switzerland & 862 & & 3.563 & 1.818 & 0.398 & & 1.330 \\
\hline Taiwan & 456 & & 1.267 & 1.121 & 0.342 & & 1.330 \\
\hline Thailand & 100 & & 2.148 & 1.534 & 0.415 & & 1.087 \\
\hline United Kingdom & 3,997 & & 4.876 & 2.070 & 0.299 & & 1.753 \\
\hline United States & 27,857 & & 4.310 & 2.004 & 0.369 & & 1.330 \\
\hline
\end{tabular}


Table 2. Summary statistics

This table summarizes the summary statistics and correlation matrix of variables in our sample. Sample period is 1995-2008. All variables are defined in the Appendix.

\begin{tabular}{|c|c|c|c|c|c|c|c|c|c|c|c|c|}
\hline \multicolumn{13}{|c|}{ Panel A: Descriptive statistics } \\
\hline & & & $\mathbf{N}$ & Mean & \multicolumn{2}{|c|}{ STD } & p10 & p25 & \multicolumn{2}{|c|}{ p50 } & p75 & p90 \\
\hline \multicolumn{3}{|c|}{ Abnormal Return Variance } & 53,362 & 3.757 & \multicolumn{2}{|c|}{7.172} & 0.107 & 0.384 & \multicolumn{2}{|c|}{1.244} & 3.714 & 9.457 \\
\hline \multicolumn{3}{|c|}{ Abnormal Trading Volume } & 53,362 & 1.851 & \multicolumn{2}{|c|}{1.727} & 0.453 & 0.823 & \multicolumn{2}{|c|}{1.377} & 2.247 & 3.639 \\
\hline \multicolumn{3}{|c|}{ Societal Trust } & 53,362 & 0.371 & \multicolumn{2}{|c|}{0.076} & 0.296 & 0.359 & \multicolumn{2}{|c|}{0.363} & 0.396 & 0.431 \\
\hline \multicolumn{3}{|c|}{ Investor Protection } & 53,362 & 1.405 & \multicolumn{2}{|c|}{0.156} & 1.330 & 1.330 & \multicolumn{2}{|c|}{1.330} & 1.500 & 1.587 \\
\hline \multicolumn{3}{|c|}{ Disclosure Requirement } & 53,362 & 0.880 & \multicolumn{2}{|c|}{0.158} & 0.670 & 0.750 & \multicolumn{2}{|c|}{1.000} & 1.000 & 1.000 \\
\hline \multicolumn{3}{|c|}{ Insider Trading } & 53,362 & 0.010 & \multicolumn{2}{|c|}{0.099} & 0.000 & 0.000 & \multicolumn{2}{|c|}{0.000} & 0.000 & 0.000 \\
\hline \multicolumn{3}{|c|}{ Firm Size } & 53,362 & 13.684 & \multicolumn{2}{|c|}{1.751} & 11.474 & 12.446 & \multicolumn{2}{|c|}{13.600} & 14.845 & 16.048 \\
\hline \multicolumn{3}{|c|}{ |UE| } & 53,362 & 0.027 & 0.1 & & 0.000 & 0.001 & 0.00 & & 0.011 & 0.036 \\
\hline Firm L & & & 53,362 & 0.542 & 0.2 & & 0.210 & 0.371 & 0.54 & & 0.706 & 0.888 \\
\hline Quarte & eporting & & 53,362 & 0.635 & 0.4 & & 0.000 & 0.000 & 1.00 & & 1.000 & 1.000 \\
\hline Report & & & 53,362 & 50.883 & 23. & & 24.000 & 33.000 & 47.00 & & 62.000 & 82.000 \\
\hline Larges & & & 53,362 & 0.037 & 0.1 & & 0.000 & 0.000 & 0.00 & & 0.000 & 0.000 \\
\hline Cross I & & & 53,362 & 0.076 & 0.2 & & 0.000 & 0.000 & 0.00 & & 0.000 & 0.000 \\
\hline Foreca & spersion & & 53,362 & 0.020 & 0.0 & & 0.001 & 0.002 & 0.00 & & 0.013 & 0.035 \\
\hline Foreca & mber & & 53,362 & 8.269 & 6.3 & & 2.000 & 3.000 & 6.00 & & 11.000 & 17.000 \\
\hline Loss D & & & 53,362 & 0.140 & 0.3 & & 0.000 & 0.000 & 0.00 & & 0.000 & 1.000 \\
\hline $\begin{array}{l}\text { Panel } \mathrm{H} \\
1 \% \text { lev }\end{array}$ & lation matrix (Pea & $\mathrm{h}$ & the dias & al; Spea & nan & ove the $c$ & diagonal & ures in & are st & & lly sign & it at the \\
\hline & & 1 & 2 & 3 & 4 & 5 & 6 & 7 & 8 & 9 & 10 & 11 \\
\hline 1 & $\begin{array}{l}\text { Abnormal Return } \\
\text { Variance }\end{array}$ & & 0.474 & 0.016 & -0.024 & 0.112 & 0.100 & 0.080 & -0.069 & 0.100 & -0.128 & -0.096 \\
\hline 2 & $\begin{array}{l}\text { Abnormal Trading } \\
\text { Volume }\end{array}$ & 0.468 & & 0.005 & -0.068 & 0.165 & 0.126 & 0.113 & -0.096 & 0.120 & -0.176 & -0.129 \\
\hline 3 & Societal Trust & 0.023 & 0.016 & & 0.196 & -0.228 & 0.038 & 0.037 & 0.015 & 0.075 & -0.024 & 0.034 \\
\hline 4 & $\begin{array}{l}\text { Investor } \\
\text { Protection }\end{array}$ & 0.005 & 0.002 & 0.059 & & -0.478 & -0.033 & 0.111 & 0.014 & -0.306 & 0.224 & 0.109 \\
\hline 5 & $\begin{array}{l}\text { Disclosure } \\
\text { Requirement }\end{array}$ & 0.074 & 0.085 & -0.207 & -0.271 & & -0.052 & -0.211 & -0.114 & 0.286 & -0.469 & -0.251 \\
\hline 6 & Firm Size & 0.048 & -0.021 & -0.011 & -0.050 & -0.051 & & -0.334 & 0.013 & 0.104 & -0.235 & -0.268 \\
\hline 7 & |UE & 0.024 & 0.028 & -0.028 & 0.067 & -0.115 & -0.109 & & 0.216 & -0.052 & 0.285 & 0.715 \\
\hline 8 & Firm Leverage & -0.034 & -0.042 & -0.008 & -0.036 & -0.041 & -0.010 & 0.166 & & -0.037 & 0.028 & 0.243 \\
\hline 9 & $\begin{array}{l}\text { Quarterly } \\
\text { Reporting }\end{array}$ & 0.087 & 0.051 & 0.013 & -0.269 & 0.202 & 0.106 & -0.035 & 0.023 & & -0.255 & -0.019 \\
\hline 10 & Reporting Lag & -0.078 & -0.086 & -0.138 & 0.133 & -0.407 & -0.228 & 0.105 & -0.015 & -0.232 & & 0.283 \\
\hline 11 & $\begin{array}{l}\text { Forecast } \\
\text { Dispersion } \\
\end{array}$ & -0.032 & -0.043 & -0.019 & 0.054 & -0.122 & -0.118 & 0.699 & 0.207 & -0.023 & 0.115 & \\
\hline
\end{tabular}


Table 3. Trust and stock market reactions surrounding earnings announcements

This table summarizes estimation of equation (1) using either abnormal returns variance (Panel A) or abnormal trading volume (Panel B) as the dependent variable. In the parentheses below coefficient estimates are robust tstatistics based on standard errors adjusted for heteroskedasticity and firm-level clustering. All continuous variables are winsorized at $1^{\text {st }}$ and $99^{\text {th }}$ percentile. $* * * * * *$ denote significance at $0.1,0.05$, and 0.01 level, respectively. All variables are defined in the Appendix.

\begin{tabular}{|c|c|c|c|c|}
\hline & \multicolumn{2}{|c|}{ Abnormal return variance } & \multicolumn{2}{|c|}{ Abnormal trading volume } \\
\hline & (1) & (2) & (3) & (4) \\
\hline Societal Trust & $\begin{array}{c}1.849 * * * \\
(4.24)\end{array}$ & $\begin{array}{c}3.658 * * * \\
(8.06)\end{array}$ & $\begin{array}{c}0.274 * * \\
(2.25)\end{array}$ & $\begin{array}{c}0.522 * * * \\
(4.20)\end{array}$ \\
\hline Investor Protection & & $\begin{array}{c}1.188 * * * \\
(4.59)\end{array}$ & & $\begin{array}{c}0.283 * * * \\
(4.26)\end{array}$ \\
\hline Disclosure Requirement & & $\begin{array}{c}5.045^{* * *} \\
(18.84)\end{array}$ & & $\begin{array}{c}1.018 * * * \\
(14.58)\end{array}$ \\
\hline Insider Trading & & $\begin{array}{l}0.048 \\
(0.24)\end{array}$ & & $\begin{array}{l}0.072 \\
(0.84)\end{array}$ \\
\hline Firm Size & & $\begin{array}{c}-0.068 * * \\
(-2.32)\end{array}$ & & $\begin{array}{c}-0.080 \text { *** } \\
(-10.95)\end{array}$ \\
\hline |UE & & $\begin{array}{c}0.764 * * * \\
(4.07)\end{array}$ & & $\begin{array}{l}0.152^{*} \\
(1.87)\end{array}$ \\
\hline Firm Leverage & & $\begin{array}{c}0.020 * * \\
(1.99)\end{array}$ & & $\begin{array}{c}0.011 * * * \\
(3.49)\end{array}$ \\
\hline Quarterly Reporting & & $\begin{array}{l}-0.171 * \\
(-1.94)\end{array}$ & & $\begin{array}{l}-0.033 \\
(-1.33)\end{array}$ \\
\hline Reporting Lag & & $\begin{array}{c}-0.010 * * * \\
(-6.85)\end{array}$ & & $\begin{array}{c}-0.005^{* * *} \\
(-10.88)\end{array}$ \\
\hline Largest 20 & & $\begin{array}{l}-0.017 \\
(-0.10)\end{array}$ & & $\begin{array}{l}0.080 \\
(1.34)\end{array}$ \\
\hline Cross Listing & & $\begin{array}{l}0.104 \\
(0.77)\end{array}$ & & $\begin{array}{l}0.052 \\
(1.54)\end{array}$ \\
\hline Forecast Dispersion & & $\begin{array}{c}-0.620 * * \\
(-2.29)\end{array}$ & & $\begin{array}{c}-0.508 * * * \\
(-4.59)\end{array}$ \\
\hline Forecast Number & & $\begin{array}{c}0.061 * * * \\
(8.22)\end{array}$ & & $\begin{array}{c}0.015^{* * * *} \\
(9.53)\end{array}$ \\
\hline Loss Dummy & & $\begin{array}{c}-0.967 * * * \\
(-10.80)\end{array}$ & & $\begin{array}{c}-0.236 * * * \\
(-9.33)\end{array}$ \\
\hline Constant & $\begin{array}{l}0.750 \\
(1.08)\end{array}$ & $\begin{array}{c}-4.892 * * * \\
(-5.19)\end{array}$ & $\begin{array}{c}1.936^{* * * *} \\
(5.34)\end{array}$ & $\begin{array}{c}1.729 * * * \\
(4.60)\end{array}$ \\
\hline Year effect & Included & Included & Included & Included \\
\hline Industry effect & Included & Included & Included & Included \\
\hline Observations & 53,362 & 53,362 & 53,362 & 53,362 \\
\hline Adj. R-squared & 0.05 & 0.07 & 0.03 & 0.05 \\
\hline
\end{tabular}


Table 4. Path analysis of the effects of trust on investor reactions to earnings announcements

This table summarizes the path analysis estimates of the relation between trust and abnormal returns variance in Panel A (abnormal trading volume in Panel B) using three paths: Reporting lag, forecast number, and earnings quality.

\begin{tabular}{|c|c|c|c|c|c|c|}
\hline \multicolumn{7}{|c|}{ Panel A: Abnormal return variance } \\
\hline & \multicolumn{2}{|c|}{ Path= Reporting Lag } & \multicolumn{2}{|c|}{ Path $=$ Forecast Number } & \multicolumn{2}{|c|}{ Path=Earnings quality } \\
\hline & Coef & t-stat & Coef & t-stat & Coef & t-stat \\
\hline \multicolumn{7}{|l|}{ Direct Path } \\
\hline$\overline{\mathrm{P}(\text { Trust, } \mathrm{Ab}} \mathrm{var})$ & $2.183 * * *$ & 4.93 & $2.183 * * *$ & 4.93 & $2.183 * * *$ & 4.93 \\
\hline \multicolumn{7}{|l|}{ Mediated Path } \\
\hline$\overline{\mathrm{P}(\text { Trust, Path) }}$ & $-43.119 * * *$ & -32.09 & $20.438 * * *$ & 10.23 & $0.126^{* * *}$ & 9.63 \\
\hline $\mathrm{P}($ Path, Abvar) & $-0.006 * * *$ & -4.04 & $0.004 * * *$ & 3.25 & $1.910 * * *$ & 10.63 \\
\hline $\begin{array}{l}\mathrm{P}(\text { Trust, Path) } * \mathrm{P}(\text { Path, } \\
\text { Abvar })\end{array}$ & $0.259 * * *$ & 4.02 & $0.082 * * *$ & 3.10 & $0.241 * * *$ & 7.14 \\
\hline Observations & \multicolumn{6}{|c|}{53,362} \\
\hline Adj. Goodness of Fit & \multirow{2}{*}{\multicolumn{6}{|c|}{0.92}} \\
\hline Index & & & & & & \\
\hline \multicolumn{7}{|c|}{ Panel B: Abnormal trading volume } \\
\hline & \multicolumn{2}{|c|}{ Path= Reporting Lag } & \multicolumn{2}{|c|}{ Path $=$ Forecast Number } & \multicolumn{2}{|c|}{ Path=Earnings quality } \\
\hline & Coef & t-stat & Coef & t-stat & Coef & t-stat \\
\hline \multicolumn{7}{|l|}{ Direct Path } \\
\hline$\overline{\mathrm{P}(\text { Trust, } \mathrm{Ab}} \mathrm{vol})$ & $0.256 * *$ & 2.37 & $0.256^{* *}$ & 2.37 & $0.256 * *$ & 2.37 \\
\hline \multicolumn{7}{|l|}{ Mediated Path } \\
\hline $\mathrm{P}$ (Trust, Path) & $-43.119 * * *$ & -32.09 & $20.438 * * *$ & 10.23 & $0.126 * * *$ & 9.63 \\
\hline P(Path, Abvol) & $-0.004 * * *$ & -11.33 & $0.007 * * *$ & 4.21 & $0.466 * * *$ & 9.41 \\
\hline $\begin{array}{l}\mathrm{P}(\text { Trust, Path)*P(Path, } \\
\text { Abvol) }\end{array}$ & $0.172 * * *$ & 10.77 & $0.143 * * *$ & 3.90 & $0.059 * * *$ & 6.73 \\
\hline Observations & \multicolumn{6}{|c|}{53,362} \\
\hline Adj. Goodness of Fit & \multicolumn{6}{|c|}{0.92} \\
\hline
\end{tabular}




\section{Table 5. Cross-country variations in the effect of trust on market reactions to earnings announcements}

This table summarizes estimation of equations (2) and (3) using either abnormal returns variance or abnormal trading volume as the dependent variable. In the parentheses below coefficient estimates are robust t-statistics based on standard errors adjusted for heteroskedasticity and firm-level clustering. All continuous variables are winsorized at $1^{\text {st }}$ and $99^{\text {th }}$ percentile. $* * *, * * *$ denote significance at $0.1,0.05$, and 0.01 level, respectively. Low Investor Protection is a binary variable that is equal to 1 if a country's investor protection index is below sample median. Low Disclosure Requirement is a binary variable equal to 1 if a country's disclosure requirement index is below sample median. Low Education Level is a binary variable that is equal to 1 if a country's average education level is below sample median. A country's education level is defined as the average years of total schooling among people older than 15 years. Education Level data is obtained from World Bank website (http://www.worldbank.org/). The data is available every 5 years. We use the data of 1995, the beginning of our sample period. The results are similar if we use the mean between 1995 and 2010. The definitions of all other variables are in the Appendix.

\begin{tabular}{|c|c|c|c|c|c|c|}
\hline & \multicolumn{3}{|c|}{ Abnormal Return Variance } & \multicolumn{3}{|c|}{ Abnormal Trading Volume } \\
\hline & (1) & (2) & (3) & (4) & $(5)$ & (6) \\
\hline & $\begin{array}{c}\text { Investor } \\
\text { Protection } \\
\end{array}$ & $\begin{array}{c}\text { Disclosure } \\
\text { Requirement }\end{array}$ & $\begin{array}{c}\text { Average } \\
\text { Education }\end{array}$ & $\begin{array}{c}\text { Investor } \\
\text { Protection } \\
\end{array}$ & $\begin{array}{c}\text { Disclosure } \\
\text { Requirement }\end{array}$ & $\begin{array}{c}\text { Average } \\
\text { Education }\end{array}$ \\
\hline Societal Trust & $\begin{array}{c}1.231 * * \\
(2.13)\end{array}$ & $\begin{array}{l}0.206 \\
(0.36)\end{array}$ & $\begin{array}{l}-0.429 \\
(-0.47)\end{array}$ & $\begin{array}{l}-0.057 \\
(-0.36)\end{array}$ & $\begin{array}{l}-0.111 \\
(-1.33)\end{array}$ & $\begin{array}{l}-0.089 \\
(-0.38)\end{array}$ \\
\hline Societal Trust*Low Investor Protection & $\begin{array}{c}7.441 * * * \\
(7.50)\end{array}$ & & & $\begin{array}{c}1.443 * * * \\
(5.27)\end{array}$ & & \\
\hline Societal Trust* Low Disclosure Requirement & & $\begin{array}{c}3.016 * * * \\
(3.17)\end{array}$ & & & $\begin{array}{c}1.214 * * * \\
(5.06)\end{array}$ & \\
\hline Societal Trust* Low Education & & & $\begin{array}{c}4.561 * * * \\
(4.04)\end{array}$ & & & $\begin{array}{c}1.058 * * * \\
(3.30)\end{array}$ \\
\hline Low Investor Protection & $\begin{array}{c}-1.702 * * * \\
(-4.80)\end{array}$ & $\begin{array}{c}-0.985 * * * \\
(-6.61)\end{array}$ & $\begin{array}{c}-1.004 * * * \\
(-6.67)\end{array}$ & $\begin{array}{c}-0.294 * * * \\
(-2.92)\end{array}$ & $\begin{array}{c}-0.050 * \\
(-1.88)\end{array}$ & $\begin{array}{c}-0.202 * * * \\
(-4.89)\end{array}$ \\
\hline Low Disclosure Requirement & $\begin{array}{c}-0.752 * * * \\
(-5.51)\end{array}$ & $\begin{array}{c}-2.051 * * * \\
(-5.11)\end{array}$ & $\begin{array}{c}-0.891 * * * \\
(-5.70)\end{array}$ & $\begin{array}{l}-0.030 \\
(-0.78)\end{array}$ & $\begin{array}{c}-0.522 * * * \\
(-5.76)\end{array}$ & $\begin{array}{c}-0.131 * * * \\
(-3.12)\end{array}$ \\
\hline Low Education Level & & & $\begin{array}{c}-1.357 * * * \\
(-3.22)\end{array}$ & & & $\begin{array}{l}-0.176 \\
(-1.54)\end{array}$ \\
\hline Insider Trading & $\begin{array}{c}0.622 * * * \\
(3.04)\end{array}$ & $\begin{array}{l}0.062 \\
(0.31)\end{array}$ & $\begin{array}{l}-0.148 \\
(-0.72)\end{array}$ & $\begin{array}{c}0.221 * * \\
(2.56)\end{array}$ & $\begin{array}{c}0.210 * * * \\
(3.01)\end{array}$ & $\begin{array}{l}-0.013 \\
(-0.16)\end{array}$ \\
\hline Firm Size & $\begin{array}{c}-0.076^{* *} \\
(-2.53)\end{array}$ & $\begin{array}{c}-0.100 * * * \\
(-3.35)\end{array}$ & $\begin{array}{c}-0.101 * * * \\
(-3.36)\end{array}$ & $\begin{array}{c}-0.078 * * * \\
(-10.46)\end{array}$ & $\begin{array}{c}-0.037 * * * \\
(-7.40)\end{array}$ & $\begin{array}{c}-0.083 * * * \\
(-11.15)\end{array}$ \\
\hline$|\mathrm{UE}|$ & $\begin{array}{c}0.698 * * * \\
(3.71)\end{array}$ & $\begin{array}{c}0.702 * * * \\
(3.72)\end{array}$ & $\begin{array}{c}0.682 * * * \\
(3.63)\end{array}$ & $\begin{array}{l}0.126 \\
(1.56)\end{array}$ & $\begin{array}{c}0.099^{*} \\
(1.95)\end{array}$ & $\begin{array}{l}0.126 \\
(1.56)\end{array}$ \\
\hline Firm Leverage & $\begin{array}{l}0.016 \\
(1.54)\end{array}$ & $\begin{array}{l}0.011 \\
(1.07)\end{array}$ & $\begin{array}{l}0.011 \\
(1.06)\end{array}$ & $\begin{array}{c}0.010 * * * \\
(3.30)\end{array}$ & $\begin{array}{c}0.007 * * * \\
(3.51)\end{array}$ & $\begin{array}{c}0.009 * * * \\
(3.05)\end{array}$ \\
\hline Quarterly Reporting & $-0.440 * * *$ & 0.128 & 0.129 & $-0.125 * * *$ & $-0.045^{* * *}$ & $0.047 *$ \\
\hline
\end{tabular}




\begin{tabular}{|c|c|c|c|c|c|c|}
\hline & $(-4.51)$ & $(1.46)$ & $(1.36)$ & $(-4.86)$ & $(-2.85)$ & $(1.80)$ \\
\hline \multirow[t]{2}{*}{ Reporting Lag } & $-0.018 * * *$ & $-0.017 * * *$ & $-0.017 * * *$ & $-0.007 * * *$ & $-0.004 * * *$ & $-0.007 * * *$ \\
\hline & $(-12.90)$ & $(-11.85)$ & $(-11.87)$ & $(-16.44)$ & $(-12.64)$ & $(-15.78)$ \\
\hline \multirow[t]{2}{*}{ Largest 20} & -0.112 & $-0.407 * *$ & $-0.384 * *$ & 0.043 & 0.043 & -0.036 \\
\hline & $(-0.66)$ & $(-2.42)$ & $(-2.27)$ & $(0.71)$ & $(1.12)$ & $(-0.60)$ \\
\hline \multirow[t]{2}{*}{ Cross Listing } & 0.008 & -0.203 & -0.135 & 0.021 & -0.019 & -0.022 \\
\hline & $(0.06)$ & $(-1.51)$ & $(-0.98)$ & $(0.61)$ & $(-0.89)$ & $(-0.64)$ \\
\hline \multirow[t]{2}{*}{ Forecast Dispersion } & $-0.902 * * *$ & $-0.734 * * *$ & $-0.775 * * *$ & $-0.596 * * *$ & $-0.435 * * *$ & $-0.559 * * *$ \\
\hline & $(-3.30)$ & $(-2.68)$ & $(-2.83)$ & $(-5.39)$ & $(-5.92)$ & $(-5.03)$ \\
\hline \multirow[t]{2}{*}{ Forecast Number } & $0.043 * * *$ & $0.057 * * *$ & $0.056^{* * *}$ & $0.010 * * *$ & $0.005^{* * *}$ & $0.013 * * *$ \\
\hline & $(5.58)$ & $(7.43)$ & $(7.20)$ & $(5.86)$ & $(4.80)$ & (7.63) \\
\hline \multirow[t]{2}{*}{ Loss Dummy } & $-0.912 * * *$ & $-0.846^{* * *}$ & $-0.850 * * *$ & $-0.219 * * *$ & $-0.107 * * *$ & $-0.199 * * *$ \\
\hline & $(-10.24)$ & $(-9.47)$ & $(-9.49)$ & $(-8.70)$ & $(-6.26)$ & $(-7.88)$ \\
\hline \multirow[t]{2}{*}{ Constant } & $2.170 * * *$ & $3.549 * * *$ & $4.007 * * *$ & $3.176 * * *$ & $2.011 * * *$ & $3.481 * * *$ \\
\hline & $(2.76)$ & (4.01) & $(4.49)$ & $(8.53)$ & (13.69) & $(9.18)$ \\
\hline Year effect & Included & Included & Included & Included & Included & Included \\
\hline Industry effect & Included & Included & Included & Included & Included & Included \\
\hline Observations & 53,362 & 53,362 & 53,362 & 53,362 & 53,334 & 53,362 \\
\hline Adj. R-squared & 0.06 & 0.06 & 0.06 & 0.05 & 0.03 & 0.04 \\
\hline
\end{tabular}




\section{Table 6. Cross-firm variations in the effect of trust on market reactions to earnings announcements}

This table presents the estimation results of equation (3). The dependent variable is abnormal return variance in columns (1)-(3) and abnormal trading volume in columns (4)-(6). In the parentheses below coefficient estimates are robust t-statistics based on standard errors adjusted for heteroskedasticity and firm-level clustering. All continuous variables are winsorized at $1^{\text {st }}$ and $99^{\text {th }}$ percentile. $* * *, * * *$ denote significance at $0.1,0.05$, and 0.01 level, respectively. All variables are defined in the Appendix.

\begin{tabular}{|c|c|c|c|c|c|c|}
\hline & \multicolumn{3}{|c|}{ Abnormal Return Variance } & \multicolumn{3}{|c|}{ Abnormal Trading Volume } \\
\hline & $(1)$ & $(2)$ & (3) & (4) & $(5)$ & $(6)$ \\
\hline & $\begin{array}{l}\text { High-tech } \\
\text { Industry }\end{array}$ & R\&D Intensity & Market-to-Book & $\begin{array}{l}\text { High-tech } \\
\text { Industry }\end{array}$ & R\&D Intensity & Market-to-Book \\
\hline Societal Trust & $\begin{array}{l}3.071 * * * \\
(6.24)\end{array}$ & $\begin{array}{l}2.919 * * * \\
(5.75)\end{array}$ & $\begin{array}{l}2.990 * * * \\
(4.82)\end{array}$ & $\begin{array}{l}0.393 * * * \\
(2.88)\end{array}$ & $\begin{array}{l}0.326^{* * *} \\
(2.23)\end{array}$ & $\begin{array}{l}0.345^{* *} \\
(2.04)\end{array}$ \\
\hline $\begin{array}{l}\text { Societal Trust* High Information } \\
\text { Asymmetry }\end{array}$ & $3.942 * * *$ & $2.125 * *$ & $1.349 *$ & $0.872 * * *$ & $0.555^{* *}$ & $0.414 *$ \\
\hline & $(3.20)$ & $(2.27)$ & $(1.69)$ & $(2.62)$ & $(2.15)$ & $(1.86)$ \\
\hline High Information Asymmetry & $\begin{array}{c}-1.192 * * \\
(-2.54)\end{array}$ & $\begin{array}{l}-0.549 \\
(-1.55)\end{array}$ & $\begin{array}{l}-0.399 \\
(-1.32)\end{array}$ & $\begin{array}{c}-0.234 * \\
(-1.84)\end{array}$ & $\begin{array}{l}-0.122 \\
(-1.24)\end{array}$ & $\begin{array}{l}-0.079 \\
(-0.94)\end{array}$ \\
\hline Investor Protection & $\begin{array}{l}1.188 * * * \\
(4.60)\end{array}$ & $\begin{array}{l}1.204 * * * \\
(4.66)\end{array}$ & $\begin{array}{l}1.187 * * * \\
(4.58)\end{array}$ & $\begin{array}{l}0.284 * * * \\
(4.28)\end{array}$ & $\begin{array}{l}0.289 * * * \\
\quad(4.37)\end{array}$ & $\begin{array}{l}0.257 * * * \\
(3.91)\end{array}$ \\
\hline Disclosure Requirement & $\begin{array}{c}5.033 * * * \\
(18.80)\end{array}$ & $\begin{array}{c}5.125 * * * \\
(19.21)\end{array}$ & $\begin{array}{c}5.050 * * * \\
(18.82)\end{array}$ & $\begin{array}{c}1.013 * * * \\
(14.54)\end{array}$ & $\begin{array}{c}1.042 * * * \\
(14.95)\end{array}$ & $\begin{array}{c}0.994 * * * \\
(14.08)\end{array}$ \\
\hline Insider Trading & $\begin{array}{l}0.063 \\
(0.31)\end{array}$ & $\begin{array}{l}0.017 \\
(0.08)\end{array}$ & $\begin{array}{l}0.041 \\
(0.21)\end{array}$ & $\begin{array}{l}0.076 \\
(0.89)\end{array}$ & $\begin{array}{l}0.061 \\
(0.71)\end{array}$ & $\begin{array}{l}0.084 \\
(0.98)\end{array}$ \\
\hline Firm Size & $\begin{array}{c}-0.064 * * \\
(-2.19)\end{array}$ & $\begin{array}{c}-0.071 * * \\
(-2.43)\end{array}$ & $\begin{array}{c}-0.076^{* *} \\
(-2.56)\end{array}$ & $\begin{array}{c}-0.079 * * * \\
(-10.79)\end{array}$ & $\begin{array}{l}-0.082 * * * \\
(-11.11)\end{array}$ & $\begin{array}{l}-0.079 * * * \\
(-10.23)\end{array}$ \\
\hline$|\mathrm{UE}|$ & $\begin{array}{c}0.765^{* * * *} \\
(4.08)\end{array}$ & $\begin{array}{c}0.782 * * * \\
(4.16)\end{array}$ & $\begin{array}{c}0.759 * * * \\
(4.05)\end{array}$ & $\begin{array}{c}0.152^{*} \\
(1.88)\end{array}$ & $\begin{array}{c}0.158 * \\
(1.95)\end{array}$ & $\begin{array}{c}0.140 * \\
(1.74)\end{array}$ \\
\hline Firm Leverage & $\begin{array}{c}0.022 * * \\
(2.16)\end{array}$ & $\begin{array}{c}0.022 * * \\
(2.13)\end{array}$ & $\begin{array}{c}0.023 * * \\
(2.28)\end{array}$ & $\begin{array}{c}0.011^{* * *} \\
(3.65)\end{array}$ & $\begin{array}{c}0.011 * * * \\
(3.64)\end{array}$ & $\begin{array}{c}0.016 * * * \\
(5.08)\end{array}$ \\
\hline Quarterly Reporting & $\begin{array}{c}-0.178 * * \\
(-2.02)\end{array}$ & $\begin{array}{l}-0.172 * \\
(-1.96)\end{array}$ & $\begin{array}{l}-0.170^{*} \\
(-1.93)\end{array}$ & $\begin{array}{l}-0.035 \\
(-1.42)\end{array}$ & $\begin{array}{l}-0.033 \\
(-1.33)\end{array}$ & $\begin{array}{c}-0.044 * \\
(-1.77)\end{array}$ \\
\hline Reporting Lag & $\begin{array}{c}-0.010 * * * \\
(-6.78)\end{array}$ & $\begin{array}{c}-0.010 * * * \\
(-6.54)\end{array}$ & $\begin{array}{c}-0.010 * * * \\
(-6.88)\end{array}$ & $\begin{array}{c}-0.005 * * * \\
(-10.78)\end{array}$ & $\begin{array}{c}-0.005 * * * \\
(-10.50)\end{array}$ & $\begin{array}{c}-0.005 * * * \\
(-10.91)\end{array}$ \\
\hline Largest 20 & $\begin{array}{l}-0.053 \\
(-0.32)\end{array}$ & $\begin{array}{l}0.003 \\
(0.02)\end{array}$ & $\begin{array}{l}-0.024 \\
(-0.14)\end{array}$ & $\begin{array}{l}0.071 \\
(1.20)\end{array}$ & $\begin{array}{l}0.088 \\
(1.47)\end{array}$ & $\begin{array}{l}0.084 \\
(1.39)\end{array}$ \\
\hline Cross Listing & $\begin{array}{l}0.088 \\
(0.65)\end{array}$ & $\begin{array}{l}0.078 \\
(0.58)\end{array}$ & $\begin{array}{l}0.108 \\
(0.80)\end{array}$ & $\begin{array}{l}0.047 \\
(1.40)\end{array}$ & $\begin{array}{l}0.043 \\
(1.28)\end{array}$ & $\begin{array}{l}0.048 \\
(1.41)\end{array}$ \\
\hline Forecast Dispersion & $-0.639 * *$ & $-0.627 * *$ & $-0.605 * *$ & $-0.513 * * *$ & $-0.510 * * *$ & $-0.502 * * *$ \\
\hline
\end{tabular}




\begin{tabular}{|c|c|c|c|c|c|c|}
\hline & $(-2.36)$ & $(-2.32)$ & $(-2.23)$ & $(-4.63)$ & $(-4.60)$ & $(-4.55)$ \\
\hline Forecast Number & $\begin{array}{c}0.060 * * * \\
(8.05)\end{array}$ & $\begin{array}{c}0.060 * * * \\
(8.13)\end{array}$ & $\begin{array}{c}0.061 * * * \\
(8.26)\end{array}$ & $\begin{array}{c}0.015^{* * * *} \\
(9.25)\end{array}$ & $\begin{array}{c}0.015^{* * *} \\
(9.43)\end{array}$ & $\begin{array}{c}0.014 * * * \\
(8.44)\end{array}$ \\
\hline Loss Dummy & $\begin{array}{c}-0.980 * * * \\
(-10.88)\end{array}$ & $\begin{array}{c}-0.993 * * * \\
(-11.01)\end{array}$ & $\begin{array}{c}-0.966 * * * \\
(-10.78)\end{array}$ & $\begin{array}{c}-0.240 * * * \\
(-9.48)\end{array}$ & $\begin{array}{c}-0.245 * * * \\
(-9.63)\end{array}$ & $\begin{array}{c}-0.251 * * * \\
(-9.78)\end{array}$ \\
\hline Constant & $\begin{array}{c}-4.769 * * * \\
(-5.05)\end{array}$ & $\begin{array}{c}-4.782 * * * \\
(-4.93)\end{array}$ & $\begin{array}{c}-4.587 * * * \\
(-4.80)\end{array}$ & $\begin{array}{c}1.752 * * * \\
(4.65)\end{array}$ & $\begin{array}{c}1.748 * * * \\
(4.58)\end{array}$ & $\begin{array}{c}1.525 * * * \\
(6.02)\end{array}$ \\
\hline Year effect & Included & Included & Included & Included & Included & Included \\
\hline Industry effect & Included & Included & Included & Included & Included & Included \\
\hline Observations & 53,362 & 53,362 & 53,362 & 53,362 & 53,362 & 53,362 \\
\hline Adj. R-squared & 0.07 & 0.07 & 0.07 & 0.05 & 0.05 & 0.05 \\
\hline
\end{tabular}




\section{Table 7. Two-stage least square regressions of market reactions to earnings announcements on trust}

This table summarizes estimation of equation (1) using two stage approach, whereby we estimate fitted value of SOCIETAL TRUST using various determinants in the first stage, and then re-estimate equation (1) in the $2^{\text {nd }}$ stage using fitted value of SOCIETAL TRUST obtained in the $1^{\text {st }}$ stage. In the parentheses below coefficient estimates are robust t-statistics based on standard errors adjusted for heteroskedasticity and firm-level clustering. All continuous variables are winsorized at $1^{\text {st }}$ and $99^{\text {th }}$ percentile. *,**,*** denote significance at $0.1,0.05$, and 0.01 level, respectively. All variables are defined in the Appendix.

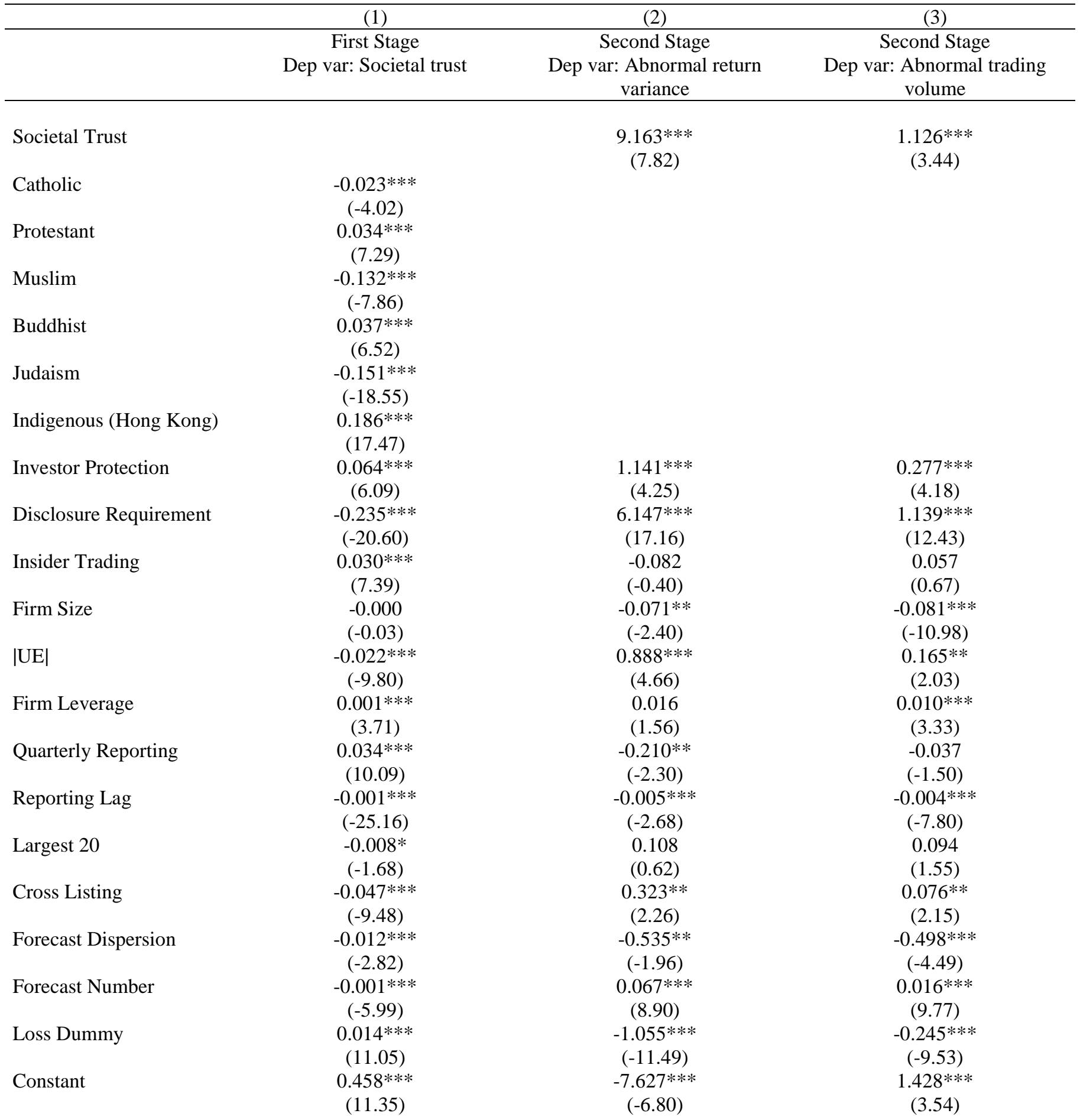


Year effect

Industry effect

Observations

Adj. R-squared
Included

Included

53,362

0.27
Included

Included

53,362

0.06
Included

Included

53,362

0.05 
Table 8. Examining the construct validity of the trust measure

This table presents regression results that demonstrate the robustness of our findings when the measure of trust is more reflective of the individuals who influence stock returns and trading volumes. In the parentheses below coefficient estimates are robust t-statistics based on standard errors adjusted for heteroskedasticity and firm-level clustering. All continuous variables are winsorized at $1^{\text {st }}$ and $99^{\text {th }}$ percentile. *,**, *** denote significance at 0.1 , 0.05 , and 0.01 level, respectively. All variables are defined in the Appendix.

\section{Panel A: Trust measure based on high income individuals}

This panel shows the effect of trust on investor reactions to earnings announcements, where trust is measured based on high income individuals. The WVS puts survey participants from each country into deciles based on their responses to an income-level related question. We construct two new trust measures based on WVS data. Trust measure is based on individuals with above-country-median incomes (deciles 6 to 10) in column (1) and (2) and based on individuals with top quintile incomes (deciles 9 and 10) in column (3) and (4).

\begin{tabular}{|c|c|c|c|c|}
\hline & \multicolumn{2}{|c|}{ Above Country-median Income } & \multicolumn{2}{|c|}{ Top Country Quintile Income } \\
\hline & $\begin{array}{c}1) \\
\begin{array}{c}\text { Abnormal Return } \\
\text { Variance }\end{array} \\
\end{array}$ & $\begin{array}{c}\text { (2) } \\
\text { Abnormal Trading } \\
\text { Volume } \\
\end{array}$ & $\begin{array}{c}\text { (3) } \\
\text { Abnormal Return } \\
\text { Variance } \\
\end{array}$ & $\begin{array}{c}\text { (4) } \\
\text { Abnormal Trading } \\
\text { Volume } \\
\end{array}$ \\
\hline Societal Trust & $\begin{array}{c}3.464 * * * \\
(8.81)\end{array}$ & $\begin{array}{c}0.655^{* * * *} \\
(6.03)\end{array}$ & $\begin{array}{c}3.265^{* * * *} \\
(10.71)\end{array}$ & $\begin{array}{c}0.589 * * * \\
(7.46)\end{array}$ \\
\hline Investor Protection & $\begin{array}{c}0.929 * * * \\
(3.51)\end{array}$ & $\begin{array}{c}0.232 * * * \\
(3.49)\end{array}$ & $\begin{array}{c}0.841^{* * *} * \\
(3.18)\end{array}$ & $\begin{array}{c}0.219 * * * \\
(3.29)\end{array}$ \\
\hline Disclosure Requirement & $\begin{array}{c}5.003 * * * \\
(18.93)\end{array}$ & $\begin{array}{c}1.044 * * * \\
(15.02)\end{array}$ & $\begin{array}{c}4.556 * * * \\
(17.73)\end{array}$ & $\begin{array}{c}0.957 * * * \\
(13.96)\end{array}$ \\
\hline Insider Trading & $\begin{array}{l}0.062 \\
(0.31)\end{array}$ & $\begin{array}{l}0.070 \\
(0.82)\end{array}$ & $\begin{array}{l}0.277 \\
(1.38)\end{array}$ & $\begin{array}{l}0.110 \\
(1.28)\end{array}$ \\
\hline Firm Size & $\begin{array}{c}-0.071 * * \\
(-2.45)\end{array}$ & $\begin{array}{c}-0.081 * * * * \\
(-11.05)\end{array}$ & $\begin{array}{c}-0.069 * * \\
(-2.38)\end{array}$ & $\begin{array}{c}-0.081 * * * \\
(-11.01)\end{array}$ \\
\hline$|\mathrm{UE}|$ & $\begin{array}{c}0.771 * * * \\
(4.11)\end{array}$ & $\begin{array}{c}0.157 * \\
(1.93)\end{array}$ & $\begin{array}{c}0.706 * * * \\
(3.77)\end{array}$ & $\begin{array}{c}0.144 * \\
(1.78)\end{array}$ \\
\hline Firm Leverage & $\begin{array}{c}0.019 * \\
(1.92)\end{array}$ & $\begin{array}{c}0.010 * * * \\
(3.40)\end{array}$ & $\begin{array}{c}0.020 * * \\
(1.99)\end{array}$ & $\begin{array}{c}0.010 * * * \\
(3.46)\end{array}$ \\
\hline Quarterly Reporting & $\begin{array}{l}-0.164 * \\
(-1.85)\end{array}$ & $\begin{array}{l}-0.033 \\
(-1.33)\end{array}$ & $\begin{array}{l}-0.046 \\
(-0.51)\end{array}$ & $\begin{array}{l}-0.012 \\
(-0.46)\end{array}$ \\
\hline Reporting Lag & $\begin{array}{c}-0.010 * * * \\
(-6.93)\end{array}$ & $\begin{array}{c}-0.005 * * * \\
(-10.57)\end{array}$ & $\begin{array}{c}-0.011 * * * \\
(-7.19)\end{array}$ & $\begin{array}{c}-0.005 * * * \\
(-10.83)\end{array}$ \\
\hline Largest 20 & $\begin{array}{l}-0.010 \\
(-0.06)\end{array}$ & $\begin{array}{l}0.086 \\
(1.43)\end{array}$ & $\begin{array}{l}-0.044 \\
(-0.27)\end{array}$ & $\begin{array}{l}0.079 \\
(1.32)\end{array}$ \\
\hline Cross Listing & $\begin{array}{l}0.115 \\
(0.85)\end{array}$ & $\begin{array}{l}0.061 * \\
(1.82)\end{array}$ & $\begin{array}{l}0.085 \\
(0.64)\end{array}$ & $\begin{array}{l}0.054 \\
(1.64)\end{array}$ \\
\hline Forecast Dispersion & $\begin{array}{c}-0.626 * * \\
(-2.31)\end{array}$ & $\begin{array}{c}-0.506 * * * \\
(-4.58)\end{array}$ & $\begin{array}{c}-0.628 * * \\
(-2.32)\end{array}$ & $\begin{array}{c}-0.507 * * * \\
(-4.59)\end{array}$ \\
\hline Forecast Number & $\begin{array}{c}0.062 * * * \\
(8.31)\end{array}$ & $\begin{array}{c}0.016^{* * *} \\
(9.75)\end{array}$ & $\begin{array}{c}0.062 * * * \\
(8.32)\end{array}$ & $\begin{array}{c}0.016^{* * *} \\
(9.74)\end{array}$ \\
\hline Loss Dummy & $\begin{array}{c}-0.978 * * * \\
(-10.90)\end{array}$ & $\begin{array}{c}-0.240 * * * \\
(-9.52)\end{array}$ & $\begin{array}{c}-0.968 * * * \\
(-10.83)\end{array}$ & $\begin{array}{c}-0.238 * * * \\
(-9.45)\end{array}$ \\
\hline Constant & $\begin{array}{c}-4.544 * * * \\
(-4.92)\end{array}$ & $\begin{array}{c}1.710^{* * * *} \\
(4.57)\end{array}$ & $\begin{array}{c}-4.125 * * * \\
(-4.56)\end{array}$ & $\begin{array}{c}1.798^{* * * *} \\
(4.80)\end{array}$ \\
\hline Year effect & Included & Included & Included & Included \\
\hline Industry effect & Included & Included & Included & Included \\
\hline Observations & 53,362 & 53,362 & 53,362 & 53,362 \\
\hline Adj. R-squared & 0.07 & 0.05 & 0.07 & 0.05 \\
\hline
\end{tabular}




\section{Panel B: Regression analysis based on countries with higher religious or ethnic homogeneity}

This panel shows the effect of trust on investor reactions to earnings announcements in subsamples of countries with higher religious or ethnic homogeneity. The responses of WVS participants to the question about religious denomination and the question about ethnic group are obtained from WVS website. We classify a country as of high religious (ethic) homogeneity if the country has a dominant religion (ethnicity). A religion or ethnicity is defined as dominant if it accounts for at least 50\% of the survey participants in a country. Column (1) and (2) show the regression results in countries of high religious homogeneity and column (3) and (4) show the regression results in countries of high ethnic homogeneity.

\begin{tabular}{|c|c|c|c|c|}
\hline & \multicolumn{2}{|c|}{ High Religious Homogeneity } & \multicolumn{2}{|c|}{ High Ethnic Homogeneity } \\
\hline & $\begin{array}{c}1) \\
\text { Abnormal Return } \\
\text { Variance } \\
\end{array}$ & $\begin{array}{c}(2) \\
\text { Abnormal Trading } \\
\text { Volume } \\
\end{array}$ & $\begin{array}{c}\text { (3) } \\
\text { Abnormal Return } \\
\text { Variance } \\
\end{array}$ & $\begin{array}{c}(4) \\
\text { Abnormal Trading } \\
\text { Volume } \\
\end{array}$ \\
\hline Societal Trust & $\begin{array}{c}2.510 * * * \\
(4.40)\end{array}$ & $\begin{array}{c}0.473 * * * \\
(2.99)\end{array}$ & $\begin{array}{c}4.572 * * * \\
(8.84)\end{array}$ & $\begin{array}{c}0.696^{* * * *} \\
(4.96)\end{array}$ \\
\hline Investor Protection & $\begin{array}{c}1.474 * * * \\
(4.23)\end{array}$ & $\begin{array}{c}0.356 * * * \\
(3.55)\end{array}$ & $\begin{array}{l}0.090 \\
(0.29)\end{array}$ & $\begin{array}{l}0.057 \\
(0.75)\end{array}$ \\
\hline Disclosure Requirement & $\begin{array}{l}0.542 \\
(1.30)\end{array}$ & $\begin{array}{l}-0.031 \\
(-0.26)\end{array}$ & $\begin{array}{c}4.982 * * * \\
(17.90)\end{array}$ & $\begin{array}{c}1.011 * * * \\
(13.87)\end{array}$ \\
\hline Insider Trading & $\begin{array}{l}-0.030 \\
(-0.13)\end{array}$ & $\begin{array}{c}0.268 * * * \\
(2.82)\end{array}$ & $\begin{array}{c}0.552 * * \\
(2.34)\end{array}$ & $\begin{array}{l}0.041 \\
(0.44)\end{array}$ \\
\hline Firm Size & $\begin{array}{c}-0.192 * * * \\
(-4.61)\end{array}$ & $\begin{array}{c}-0.119 * * * \\
(-10.07)\end{array}$ & $\begin{array}{c}-0.071 * * \\
(-2.36)\end{array}$ & $\begin{array}{c}-0.089 * * * \\
(-11.90)\end{array}$ \\
\hline$|\mathrm{UE}|$ & $\begin{array}{l}0.213 \\
(1.09)\end{array}$ & $\begin{array}{l}0.039 \\
(0.40)\end{array}$ & $\begin{array}{c}0.696 * * * \\
(3.74)\end{array}$ & $\begin{array}{c}0.153^{*} \\
(1.89)\end{array}$ \\
\hline Firm Leverage & $\begin{array}{l}0.019 \\
(1.57)\end{array}$ & $\begin{array}{c}0.016^{* * * *} \\
(3.28)\end{array}$ & $\begin{array}{c}0.022 * * \\
(2.15)\end{array}$ & $\begin{array}{c}0.010 * * * \\
(3.35)\end{array}$ \\
\hline Quarterly Reporting & $\begin{array}{c}-0.463 * * * \\
(-3.60)\end{array}$ & $\begin{array}{c}-0.170 * * * \\
(-4.74)\end{array}$ & $\begin{array}{l}0.068 \\
(0.73)\end{array}$ & $\begin{array}{l}0.008 \\
(0.32)\end{array}$ \\
\hline Reporting Lag & $\begin{array}{c}-0.011 * * * \\
(-6.12)\end{array}$ & $\begin{array}{c}-0.007 * * * \\
(-11.20)\end{array}$ & $\begin{array}{c}-0.012 * * * \\
(-7.10)\end{array}$ & $\begin{array}{c}-0.004 * * * \\
(-9.50)\end{array}$ \\
\hline Largest 20 & $\begin{array}{l}0.025 \\
(0.14)\end{array}$ & $\begin{array}{l}0.086 \\
(1.26)\end{array}$ & $\begin{array}{l}-0.052 \\
(-0.30)\end{array}$ & $\begin{array}{l}0.070 \\
(1.08)\end{array}$ \\
\hline Cross Listing & $\begin{array}{c}0.279^{*} \\
(1.88)\end{array}$ & $\begin{array}{l}0.036 \\
(0.97)\end{array}$ & $\begin{array}{l}0.192 \\
(1.28)\end{array}$ & $\begin{array}{l}0.053 \\
(1.43)\end{array}$ \\
\hline Forecast Dispersion & $\begin{array}{c}-0.527 * * \\
(-1.96)\end{array}$ & $\begin{array}{c}-0.393 * * * \\
(-3.13)\end{array}$ & $\begin{array}{l}-0.395 \\
(-1.45)\end{array}$ & $\begin{array}{c}-0.438 * * * \\
(-3.94)\end{array}$ \\
\hline Forecast Number & $\begin{array}{c}0.072 * * * \\
(6.98)\end{array}$ & $\begin{array}{c}0.019 * * * \\
(7.35)\end{array}$ & $\begin{array}{c}0.062 * * * \\
(7.87)\end{array}$ & $\begin{array}{c}0.016 * * * \\
(9.72)\end{array}$ \\
\hline Loss Dummy & $\begin{array}{c}-0.596 * * * \\
(-5.19)\end{array}$ & $\begin{array}{c}-0.160 * * * \\
(-3.98)\end{array}$ & $\begin{array}{c}-1.002 * * * \\
(-11.04)\end{array}$ & $\begin{array}{c}-0.260 * * * \\
(-10.15)\end{array}$ \\
\hline Constant & $\begin{array}{l}0.417 \\
(0.38)\end{array}$ & $\begin{array}{c}2.656 * * * \\
(3.85)\end{array}$ & $\begin{array}{c}-3.741 * * * \\
(-3.86)\end{array}$ & $\begin{array}{c}1.949 * * * \\
(5.04)\end{array}$ \\
\hline Year effect & Included & Included & Included & Included \\
\hline Industry effect & Included & Included & Included & Included \\
\hline Observations & 20,174 & 20,174 & 48,964 & 48,964 \\
\hline Adj. R-squared & 0.06 & 0.05 & 0.08 & 0.05 \\
\hline
\end{tabular}




\section{Panel C: Regression analysis based on countries with lower foreign institutional ownership}

This panel shows the effect of trust on investor reactions to earnings announcements in subsample of country-years where the aggregate foreign institutional ownership is below sample median. Foreign Institutional ownership data is obtained from FactSet's LionShares database. Country level foreign institutional ownership is calculated as aggregate foreign institutional ownership in one country-year divided country market capitalization. Column (1) shows the regression results for abnormal return variance and column (2) shows the results for abnormal trading volume.

\begin{tabular}{|c|c|c|}
\hline & $\begin{array}{c}(1) \\
\text { Abnormal Return } \\
\text { Variance }\end{array}$ & $\begin{array}{c}(2) \\
\text { Abnormal Trading } \\
\text { Volume }\end{array}$ \\
\hline Societal Trust & $\begin{array}{c}4.321 * * * \\
(6.54)\end{array}$ & $\begin{array}{c}0.868 * * * \\
(3.90)\end{array}$ \\
\hline Investor Protection & $\begin{array}{l}-0.380 \\
(-0.80)\end{array}$ & $\begin{array}{c}0.134 * * \\
(2.13)\end{array}$ \\
\hline Disclosure Requirement & $\begin{array}{c}-1.196 * * \\
(-2.04)\end{array}$ & $\begin{array}{l}0.221 \\
(1.06)\end{array}$ \\
\hline Firm Size & $\begin{array}{c}-0.212 * * * \\
(-3.76)\end{array}$ & $\begin{array}{c}-0.126 * * * \\
(-8.13)\end{array}$ \\
\hline |UE $\mid$ & $\begin{array}{c}1.710 * * \\
(2.25)\end{array}$ & $\begin{array}{l}0.085 \\
(0.30)\end{array}$ \\
\hline Firm Leverage & $\begin{array}{l}-0.029 \\
(-1.51)\end{array}$ & $\begin{array}{c}0.020 * * \\
(2.56)\end{array}$ \\
\hline Quarterly Reporting & $\begin{array}{l}-0.139 \\
-0.88)\end{array}$ & $\begin{array}{c}-0.080^{*} \\
(-1.91)\end{array}$ \\
\hline Reporting Lag & $\begin{array}{c}-0.016 * * * \\
(-6.92)\end{array}$ & $\begin{array}{c}-0.007 * * * \\
(-7.55)\end{array}$ \\
\hline Largest 20 & $\begin{array}{l}0.001 \\
(0.00)\end{array}$ & $\begin{array}{l}0.056 \\
(0.55)\end{array}$ \\
\hline Cross Listing & $\begin{array}{l}0.170 \\
(0.91)\end{array}$ & $\begin{array}{l}0.059 \\
(1.17)\end{array}$ \\
\hline Forecast Dispersion & $\begin{array}{c}-3.034 * * \\
(-2.16)\end{array}$ & $\begin{array}{c}-1.738 * * * \\
(-3.30)\end{array}$ \\
\hline Forecast Number & $\begin{array}{c}0.025^{*} \\
(1.69)\end{array}$ & $\begin{array}{c}0.013^{* * * *} \\
(3.39)\end{array}$ \\
\hline Loss Dummy & $\begin{array}{c}-0.669 * * * \\
(-4.29)\end{array}$ & $\begin{array}{l}-0.044 \\
(-0.72)\end{array}$ \\
\hline Constant & $\begin{array}{c}5.132 * * * \\
(3.52)\end{array}$ & $\begin{array}{c}2.985^{* * * *} \\
(10.12)\end{array}$ \\
\hline Year effect & Included & Included \\
\hline Industry effect & Included & Included \\
\hline Observations & 10,359 & 10,359 \\
\hline Adj. R-squared & 0.06 & 0.03 \\
\hline
\end{tabular}




\section{Panel D: Regression analysis based on countries with lower (foreign and domestic) institutional ownership}

This panel shows the effect of trust on investor reactions to earnings announcements in subsample of country-years where the aggregate institutional ownership, foreign and domestic, is below sample median. Institutional ownership data is obtained from FactSet's LionShares database. Country level institutional ownership is calculated as aggregate institutional ownership in one country-year divided country market capitalization. Column (1) shows the regression results for abnormal return variance and column (2) shows the results for abnormal trading volume.

\begin{tabular}{|c|c|c|}
\hline & $\begin{array}{c}(1) \\
\text { Abnormal Return } \\
\text { Variance }\end{array}$ & $\begin{array}{c}(2) \\
\text { Abnormal Trading } \\
\text { Volume }\end{array}$ \\
\hline Societal Trust & $\begin{array}{c}2.994 * * * \\
(5.08)\end{array}$ & $\begin{array}{c}0.519 * * \\
(2.22)\end{array}$ \\
\hline Investor Protection & $\begin{array}{l}-0.616 \\
(-1.31)\end{array}$ & $\begin{array}{c}0.146^{* * *} \\
(2.23)\end{array}$ \\
\hline Disclosure Requirement & $\begin{array}{c}-1.290^{*} \\
(-1.79)\end{array}$ & $\begin{array}{l}0.366 \\
(1.54)\end{array}$ \\
\hline Firm Size & $\begin{array}{c}-0.190 * * * \\
(-3.30)\end{array}$ & $\begin{array}{c}-0.113 * * * \\
(-7.16)\end{array}$ \\
\hline |UE| & $\begin{array}{c}1.666^{* *} \\
(2.17)\end{array}$ & $\begin{array}{l}-0.006 \\
(-0.02)\end{array}$ \\
\hline Firm Leverage & $\begin{array}{l}-0.025 \\
(-1.27)\end{array}$ & $\begin{array}{c}0.023 * * * \\
(2.86)\end{array}$ \\
\hline Quarterly Reporting & $\begin{array}{c}-0.331 * * \\
(-2.06)\end{array}$ & $\begin{array}{c}-0.152 * * * \\
(-3.40)\end{array}$ \\
\hline Reporting Lag & $\begin{array}{c}-0.018 * * * \\
(-7.74)\end{array}$ & $\begin{array}{c}-0.007 * * * \\
(-7.38)\end{array}$ \\
\hline Largest 20 & $\begin{array}{l}0.066 \\
(0.23)\end{array}$ & $\begin{array}{l}0.070 \\
(0.69)\end{array}$ \\
\hline Cross Listing & $\begin{array}{l}0.121 \\
(0.65)\end{array}$ & $\begin{array}{l}0.040 \\
(0.77)\end{array}$ \\
\hline Forecast Dispersion & $\begin{array}{c}-3.271 * * \\
(-2.29)\end{array}$ & $\begin{array}{c}-1.796 * * * \\
(-3.33)\end{array}$ \\
\hline Forecast Number & $\begin{array}{l}0.016 \\
(1.06)\end{array}$ & $\begin{array}{c}0.011^{* * *} \\
(2.63)\end{array}$ \\
\hline Loss Dummy & $\begin{array}{c}-0.608 * * * \\
(-3.79)\end{array}$ & $\begin{array}{l}-0.031 \\
(-0.49)\end{array}$ \\
\hline Constant & $\begin{array}{c}5.751 * * * \\
(3.65)\end{array}$ & $\begin{array}{c}2.818 * * * * \\
(8.62)\end{array}$ \\
\hline Year effect & Included & Included \\
\hline Industry effect & Included & Included \\
\hline Observations & 10,116 & 10,116 \\
\hline Adj. R-squared & 0.05 & 0.03 \\
\hline
\end{tabular}




\section{Panel E: Regression analysis based on firms with lower institutional ownership}

This panel shows the effect of trust on investor reactions to earnings announcements in subsample of firms whose total institutional ownership, foreign and domestic, is below the median of their corresponding country-year cohort. Institutional ownership data are obtained from FactSet's LionShares database. Firm level institutional ownership is calculated as aggregate institutional ownership in one firm. Column (1) shows the regression results for abnormal return variance and column (2) shows the results for abnormal trading volume.

\begin{tabular}{|c|c|c|}
\hline & $\begin{array}{c}(1) \\
\text { Abnormal Return } \\
\text { Variance }\end{array}$ & $\begin{array}{c}(2) \\
\text { Abnormal Trading } \\
\text { Volume }\end{array}$ \\
\hline Societal Trust & $\begin{array}{c}2.878 * * * \\
(4.79)\end{array}$ & $\begin{array}{c}0.456 * * \\
(2.48)\end{array}$ \\
\hline Investor Protection & $\begin{array}{c}1.620 * * * \\
(4.30)\end{array}$ & $\begin{array}{c}0.318 * * * \\
(3.16)\end{array}$ \\
\hline Disclosure Requirement & $\begin{array}{c}4.131^{* * *} \\
(10.23)\end{array}$ & $\begin{array}{c}0.769 * * * \\
(7.17)\end{array}$ \\
\hline Firm Size & $\begin{array}{l}-0.011 \\
(-0.23)\end{array}$ & $\begin{array}{c}-0.055^{* * * *} \\
(-4.67)\end{array}$ \\
\hline |UE & $\begin{array}{c}1.649 * * * \\
(3.10)\end{array}$ & $\begin{array}{l}-0.035 \\
(-0.24)\end{array}$ \\
\hline Firm Leverage & $\begin{array}{l}0.013 \\
(0.95)\end{array}$ & $\begin{array}{c}0.019 * * * \\
(4.46)\end{array}$ \\
\hline Quarterly Reporting & $\begin{array}{c}-0.283^{* *} \\
(-2.09)\end{array}$ & $\begin{array}{c}-0.091 * * \\
(-2.34)\end{array}$ \\
\hline Reporting Lag & $\begin{array}{c}-0.009 * * * \\
(-3.61)\end{array}$ & $\begin{array}{c}-0.005^{* * * *} \\
(-7.14)\end{array}$ \\
\hline Largest 20 & $\begin{array}{l}0.069 \\
(0.32)\end{array}$ & $\begin{array}{c}0.242 * * * \\
(2.98)\end{array}$ \\
\hline Cross Listing & $\begin{array}{l}0.019 \\
(0.08)\end{array}$ & $\begin{array}{l}0.028 \\
(0.50)\end{array}$ \\
\hline Forecast Dispersion & $\begin{array}{c}-1.446^{*} \\
(-1.65)\end{array}$ & $\begin{array}{c}-0.922 * * * \\
(-3.47)\end{array}$ \\
\hline Forecast Number & $\begin{array}{c}0.076 * * * \\
(5.62)\end{array}$ & $\begin{array}{c}0.012 * * * \\
(4.18)\end{array}$ \\
\hline Loss Dummy & $\begin{array}{c}-0.906 * * * \\
(-6.69)\end{array}$ & $\begin{array}{c}-0.198 * * * \\
(-4.97)\end{array}$ \\
\hline Constant & $\begin{array}{c}-4.633 * * * \\
(-3.12)\end{array}$ & $\begin{array}{c}1.843 * * * * \\
(3.68)\end{array}$ \\
\hline Year effect & Included & Included \\
\hline Industry effect & Included & Included \\
\hline Observations & 20,904 & 20,904 \\
\hline Adj. R-squared & 0.05 & 0.04 \\
\hline
\end{tabular}




\section{Panel F: Education and the effect of trust on market reactions to earnings news: Based on high income individuals}

This table examines whether the effect of trust on investor reactions to earnings announcements varies with education, where trust and education are both measured based on high income individuals. The trust and education measures are based on individuals with above-country-median incomes (deciles 6 to 10) in column (1) and (2) and based on individuals with top quintile incomes (deciles 9 and 10) in column (3) and (4). Low Education is defined as an indicator variable equal to one if the average highest education level achieved by higher-income individuals in one country is below the median of all countries.

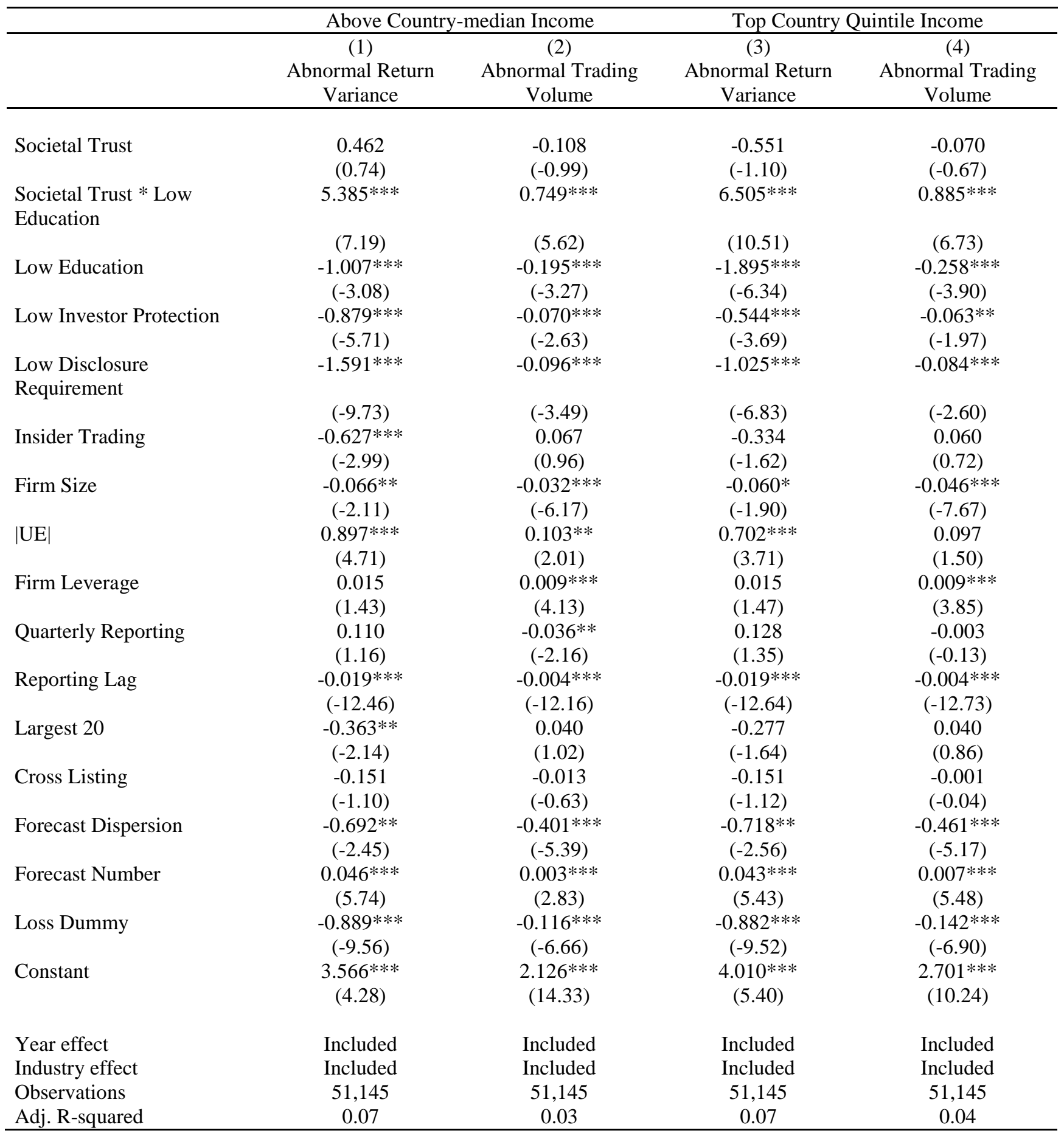




\section{Panel G: Education and the effect of trust on market reactions to earnings news: Based on firms with lower institutional ownership}

This table examines whether the effect of trust on investor reactions to earnings announcements varies with education in the subsample of firms whose total institutional ownership, foreign and domestic, is below the median of their corresponding country-year cohort. Institutional ownership data are obtained from FactSet's LionShares database. Firm level institutional ownership is calculated as aggregate institutional ownership in one firm.

\begin{tabular}{|c|c|c|}
\hline & (1) & (2) \\
\hline & $\begin{array}{c}\text { Abnormal Return } \\
\text { Variance }\end{array}$ & $\begin{array}{c}\text { Abnormal Trading } \\
\text { Volume }\end{array}$ \\
\hline Societal Trust & $\begin{array}{l}-1.083 \\
(-0.87)\end{array}$ & $\begin{array}{l}-0.141 \\
(-0.52)\end{array}$ \\
\hline Societal Trust* Low & $6.476 * * *$ & $1.935 * * *$ \\
\hline Education & $(4.50)$ & $(4.22)$ \\
\hline Low Education & $\begin{array}{c}-1.822 * * * \\
(-3.32)\end{array}$ & $\begin{array}{c}-0.336 * * \\
(-2.20)\end{array}$ \\
\hline Low Investor Protection & $\begin{array}{c}-1.167 * * * \\
(-5.34)\end{array}$ & $\begin{array}{c}-0.165^{* *} \\
(-2.53)\end{array}$ \\
\hline $\begin{array}{l}\text { Low Disclosure } \\
\text { Requirement }\end{array}$ & $-0.874 * * *$ & $-0.296 * * *$ \\
\hline Firm Size & $\begin{array}{l}(-3.46) \\
-0.051 \\
(-1.09)\end{array}$ & $\begin{array}{c}(-4.26) \\
-0.065^{* * *} \\
(-5.69)\end{array}$ \\
\hline |UE & $\begin{array}{c}1.794 * * * \\
(3.38)\end{array}$ & $\begin{array}{l}0.090 \\
(0.61)\end{array}$ \\
\hline Firm Leverage & $\begin{array}{l}0.004 \\
(0.27)\end{array}$ & $\begin{array}{l}0.015 * * * \\
(3.79)\end{array}$ \\
\hline Quarterly Reporting & $\begin{array}{l}-0.100 \\
(-0.65)\end{array}$ & $\begin{array}{l}0.016 \\
(0.43)\end{array}$ \\
\hline Reporting Lag & $\begin{array}{c}-0.013 * * * \\
(-5.52)\end{array}$ & $\begin{array}{c}-0.006 * * * \\
(-9.18)\end{array}$ \\
\hline Largest 20 & $\begin{array}{l}-0.165 \\
(-0.75)\end{array}$ & $\begin{array}{l}0.136^{*} \\
(1.75)\end{array}$ \\
\hline Cross Listing & $\begin{array}{l}-0.035 \\
(-0.15)\end{array}$ & $\begin{array}{l}0.014 \\
(0.26)\end{array}$ \\
\hline Forecast Dispersion & $\begin{array}{c}-1.617^{*} \\
(-1.86)\end{array}$ & $-0.929 * * *$ \\
\hline Forecast Number & $\begin{array}{l}0.078 * * * \\
\quad(5.70)\end{array}$ & $\begin{array}{l}0.014 * * * \\
(4.97)\end{array}$ \\
\hline Loss Dummy & $\begin{array}{c}-0.807 * * * \\
(-5.96)\end{array}$ & $\begin{array}{c}-0.161 * * * \\
(-4.17)\end{array}$ \\
\hline Constant & $\begin{array}{l}3.780 * * * \\
(2.81)\end{array}$ & $\begin{array}{c}3.374 * * * \\
(7.41)\end{array}$ \\
\hline Year effect & Included & Included \\
\hline Industry effect & Included & Included \\
\hline Observations & 20,904 & 20,904 \\
\hline Adj. R-squared & 0.05 & 0.04 \\
\hline
\end{tabular}


Table 9. Robustness tests

This table presents the results of our robustness tests of the estimation of equation (1). In the parentheses below coefficient estimates are robust t-statistics based on standard errors adjusted for heteroskedasticity and firm-level clustering. All continuous variables are winsorized at $1^{\text {st }}$ and $99^{\text {th }}$ percentile. *,**,*** denote significance at $0.1,0.05$, and 0.01 level, respectively. All variables are defined in the Appendix.

\section{Panel A: Controlling for additional country-level characteristics or country fixed effects}

\begin{tabular}{|c|c|c|c|c|c|c|c|c|}
\hline & \multicolumn{4}{|c|}{ Abnormal Return Variance } & \multicolumn{4}{|c|}{ Abnormal Trading Volume } \\
\hline & $(1)$ & $(2)$ & (3) & $(4)$ & $(5)$ & $(6)$ & $(7)$ & $(8)$ \\
\hline & $\begin{array}{c}\text { Additional } \\
\text { country-level } \\
\text { controls }\end{array}$ & $\begin{array}{l}\text { Controlling for } \\
\text { WVS other } \\
\text { cultural } \\
\text { dimensions } \\
\end{array}$ & $\begin{array}{l}\text { Controlling for } \\
\text { Hofstede } \\
\text { cultural } \\
\text { dimensions } \\
\end{array}$ & $\begin{array}{c}\text { Controlling for } \\
\text { country fixed } \\
\text { effect }\end{array}$ & $\begin{array}{c}\text { Additional } \\
\text { country-level } \\
\text { controls }\end{array}$ & $\begin{array}{l}\text { Controlling for } \\
\text { WVS other } \\
\text { cultural } \\
\text { dimensions } \\
\end{array}$ & $\begin{array}{l}\text { Controlling for } \\
\text { Hofstede } \\
\text { cultural } \\
\text { dimensions } \\
\end{array}$ & $\begin{array}{l}\text { Controlling for } \\
\text { country fixed } \\
\text { effect }\end{array}$ \\
\hline Societal Trust & $\begin{array}{c}1.736 * * * \\
(3.62)\end{array}$ & $\begin{array}{c}1.894 * * * \\
(2.78)\end{array}$ & $\begin{array}{c}1.598 * * * \\
(2.94)\end{array}$ & $\begin{array}{c}5.525 * * * \\
(4.53)\end{array}$ & $\begin{array}{c}0.744 * * * \\
(4.37)\end{array}$ & $\begin{array}{c}0.748 * * * \\
(3.81)\end{array}$ & $\begin{array}{c}0.595^{* * *} \\
(2.96)\end{array}$ & $\begin{array}{c}0.491 * * \\
(2.16)\end{array}$ \\
\hline Common Law Origin & $\begin{array}{c}-1.428 * * * \\
(-6.46)\end{array}$ & $\begin{array}{c}-1.123 * * * \\
(-3.28)\end{array}$ & $\begin{array}{c}-2.222 * * * \\
(-8.64)\end{array}$ & & $\begin{array}{c}-0.341 * * * \\
(-4.07)\end{array}$ & $\begin{array}{c}-0.410 * * * \\
(-3.80)\end{array}$ & $\begin{array}{c}-0.559 * * * \\
(-5.58)\end{array}$ & \\
\hline Stock Market & -0.001 & -0.000 & 0.002 & & $0.001 *$ & $0.001 * *$ & $0.001 * *$ & \\
\hline & $(-0.41)$ & $(-0.00)$ & $(1.30)$ & & $(1.73)$ & $(2.36)$ & $(2.25)$ & \\
\hline Earnings Quality Index & $\begin{array}{c}2.892 * * * \\
(9.67)\end{array}$ & $\begin{array}{c}2.770 * * * \\
(6.86)\end{array}$ & $\begin{array}{c}3.278 * * * \\
(7.23)\end{array}$ & & $\begin{array}{c}0.479 * * * \\
(4.43)\end{array}$ & $\begin{array}{c}0.643 * * * \\
(6.24)\end{array}$ & $\begin{array}{l}-0.156 \\
(-0.76)\end{array}$ & \\
\hline CIFAR Index & $\begin{array}{c}0.078 * * * \\
(6.79)\end{array}$ & $\begin{array}{c}0.055^{* * * *} \\
(2.78)\end{array}$ & $\begin{array}{c}0.029 * * \\
(2.23)\end{array}$ & & $\begin{array}{c}0.015^{* * * *} \\
(2.86)\end{array}$ & $\begin{array}{c}0.011 * * \\
(2.12)\end{array}$ & $\begin{array}{l}0.005 \\
(0.69)\end{array}$ & \\
\hline Hierarchy & & $\begin{array}{c}1.610 * * * \\
(2.81)\end{array}$ & & & & $\begin{array}{c}-0.350 * * \\
(-2.30)\end{array}$ & & \\
\hline Individualism & & $\begin{array}{l}1.026 \\
(1.08)\end{array}$ & $\begin{array}{c}0.016 * * * \\
(3.72)\end{array}$ & & & $\begin{array}{l}0.078 \\
(0.24)\end{array}$ & $\begin{array}{c}0.011 * * * \\
(5.53)\end{array}$ & \\
\hline Power Distance & & & $\begin{array}{l}0.001 \\
(0.12)\end{array}$ & & & & $\begin{array}{c}0.006 * * \\
(2.06)\end{array}$ & \\
\hline Uncertainty Avoidance & & & $\begin{array}{c}-0.022 * * * \\
(-4.92)\end{array}$ & & & & $\begin{array}{l}-0.002 \\
(-0.98)\end{array}$ & \\
\hline Masculinity & & & $\begin{array}{c}0.028 * * * \\
(6.60)\end{array}$ & & & & $\begin{array}{c}-0.005 * * \\
(-2.13)\end{array}$ & \\
\hline Investor Protection & $\begin{array}{l}0.140 \\
(0.44)\end{array}$ & $\begin{array}{c}-1.234 * * * \\
(-2.73)\end{array}$ & $\begin{array}{c}1.059 * * * \\
(3.07)\end{array}$ & & $\begin{array}{l}-0.201 \\
(-1.47)\end{array}$ & $\begin{array}{c}-0.362 * * \\
(-2.52)\end{array}$ & $\begin{array}{c}-0.422 * * \\
(-2.02)\end{array}$ & \\
\hline Disclosure Requirement & $\begin{array}{c}3.960 * * * \\
(9.31)\end{array}$ & $\begin{array}{c}2.070 * * \\
(2.43)\end{array}$ & $\begin{array}{c}2.898 * * * \\
(4.90)\end{array}$ & & $\begin{array}{c}1.065^{* * *} * \\
(5.10)\end{array}$ & $\begin{array}{c}1.179 * * * \\
(5.01)\end{array}$ & $\begin{array}{c}1.468 * * * \\
(4.84)\end{array}$ & \\
\hline
\end{tabular}




\begin{tabular}{|c|c|c|c|c|c|c|c|c|}
\hline Insider Trading & $\begin{array}{c}0.990 * * * \\
(4.65)\end{array}$ & $\begin{array}{c}1.375 * * * \\
(6.03)\end{array}$ & $\begin{array}{c}1.115^{* * *} * \\
(5.06)\end{array}$ & & $\begin{array}{c}0.424 * * * \\
(4.60)\end{array}$ & $\begin{array}{c}0.373^{* * * *} \\
(4.07)\end{array}$ & $\begin{array}{c}0.393 * * * \\
(4.26)\end{array}$ & \\
\hline Firm Size & $\begin{array}{l}-0.013 \\
(-0.44)\end{array}$ & $\begin{array}{l}-0.034 \\
(-1.08)\end{array}$ & $\begin{array}{l}-0.027 \\
(-0.89)\end{array}$ & $\begin{array}{l}-0.030 \\
(-0.98)\end{array}$ & $\begin{array}{c}-0.063 * * * \\
(-7.98)\end{array}$ & $\begin{array}{c}-0.090 * * * \\
(-11.83)\end{array}$ & $\begin{array}{c}-0.084 * * * \\
(-10.92)\end{array}$ & $\begin{array}{c}-0.021 * * * \\
(-4.30)\end{array}$ \\
\hline$|\mathrm{UE}|$ & $\begin{array}{c}0.700 * * * \\
(3.71)\end{array}$ & $\begin{array}{c}0.612 * * * \\
(3.27)\end{array}$ & $\begin{array}{c}0.763 * * * \\
(4.02)\end{array}$ & $\begin{array}{c}0.862 * * * \\
(4.61)\end{array}$ & $\begin{array}{l}0.106 \\
(1.33)\end{array}$ & $\begin{array}{l}0.103 \\
(1.29)\end{array}$ & $\begin{array}{l}0.095 \\
(1.19)\end{array}$ & $\begin{array}{c}0.131 * * * \\
(2.92)\end{array}$ \\
\hline Firm Leverage & $\begin{array}{c}0.030 * * * \\
(2.96)\end{array}$ & $\begin{array}{c}0.025 * * \\
(2.12)\end{array}$ & $\begin{array}{c}0.025 * * \\
(2.50)\end{array}$ & $\begin{array}{c}0.023 * * \\
(2.27)\end{array}$ & $\begin{array}{c}0.015^{* * * *} \\
(4.56)\end{array}$ & $\begin{array}{c}0.008 * * \\
(2.55)\end{array}$ & $\begin{array}{c}0.007 * * \\
(2.42)\end{array}$ & $\begin{array}{c}0.008 * * * \\
(4.45)\end{array}$ \\
\hline Quarterly Reporting & $\begin{array}{c}-0.177 * * \\
(-2.00)\end{array}$ & $\begin{array}{l}0.009 \\
(0.10)\end{array}$ & $\begin{array}{l}0.031 \\
(0.32)\end{array}$ & $\begin{array}{l}0.064 \\
(0.59)\end{array}$ & $\begin{array}{l}0.019 \\
(0.67)\end{array}$ & $\begin{array}{l}0.008 \\
(0.28)\end{array}$ & $\begin{array}{c}-0.080 * * \\
(-2.40)\end{array}$ & $\begin{array}{c}-0.119 * * * \\
(-5.55)\end{array}$ \\
\hline Reporting Lag & $\begin{array}{c}-0.010 * * * \\
(-6.47)\end{array}$ & $\begin{array}{c}-0.011 * * * \\
(-6.24)\end{array}$ & $\begin{array}{c}-0.011 * * * \\
(-6.77)\end{array}$ & $\begin{array}{c}-0.009 * * * \\
(-5.37)\end{array}$ & $\begin{array}{c}-0.006 * * * \\
(-11.42)\end{array}$ & $\begin{array}{c}-0.007 * * * \\
(-13.95)\end{array}$ & $\begin{array}{c}-0.007 * * * \\
(-13.54)\end{array}$ & $\begin{array}{c}-0.004 * * * \\
(-11.50)\end{array}$ \\
\hline Largest 20 & $\begin{array}{l}-0.166 \\
(-1.00)\end{array}$ & $\begin{array}{c}-0.320^{*} \\
(-1.83)\end{array}$ & $\begin{array}{l}0.128 \\
(0.75)\end{array}$ & $\begin{array}{l}0.018 \\
(0.10)\end{array}$ & $\begin{array}{l}0.025 \\
(0.39)\end{array}$ & $\begin{array}{l}0.010 \\
(0.15)\end{array}$ & $\begin{array}{l}0.055 \\
(0.83)\end{array}$ & $\begin{array}{l}0.035 \\
(0.94)\end{array}$ \\
\hline Cross Listing & $\begin{array}{l}0.029 \\
(0.23)\end{array}$ & $\begin{array}{l}-0.053 \\
(-0.39)\end{array}$ & $\begin{array}{l}0.068 \\
(0.53)\end{array}$ & $\begin{array}{l}0.078 \\
(0.60)\end{array}$ & $\begin{array}{l}0.008 \\
(0.22)\end{array}$ & $\begin{array}{l}0.045 \\
(1.22)\end{array}$ & $\begin{array}{c}0.071^{*} \\
(1.95)\end{array}$ & $\begin{array}{c}0.043^{*} \\
(1.96)\end{array}$ \\
\hline Forecast Dispersion & $\begin{array}{c}-0.823 * * * \\
(-3.02)\end{array}$ & $\begin{array}{c}-0.667 * * \\
(-2.49)\end{array}$ & $\begin{array}{c}-0.712 * * * \\
(-2.62)\end{array}$ & $\begin{array}{c}-0.682 * * \\
(-2.52)\end{array}$ & $\begin{array}{c}-0.497 * * * \\
(-4.52)\end{array}$ & $\begin{array}{c}-0.535 * * * \\
(-4.83)\end{array}$ & $\begin{array}{c}-0.547 * * * \\
(-4.91)\end{array}$ & $\begin{array}{c}-0.424 * * * \\
(-6.31)\end{array}$ \\
\hline Forecast Number & $\begin{array}{c}0.045^{* * * *} \\
(6.00)\end{array}$ & $\begin{array}{c}0.052 * * * \\
(6.43)\end{array}$ & $\begin{array}{c}0.046 * * * \\
(6.02)\end{array}$ & $\begin{array}{c}0.046^{* * * *} \\
(5.91)\end{array}$ & $\begin{array}{c}0.010 * * * \\
(5.85)\end{array}$ & $\begin{array}{c}0.012 * * * \\
(6.95)\end{array}$ & $\begin{array}{c}0.010 * * * \\
(5.80)\end{array}$ & $\begin{array}{c}0.006^{* * * *} \\
(5.38)\end{array}$ \\
\hline Loss Dummy & $\begin{array}{c}-0.947 * * * \\
(-10.63)\end{array}$ & $\begin{array}{c}-0.942 * * * \\
(-10.14)\end{array}$ & $\begin{array}{c}-0.984 * * * \\
(-11.00)\end{array}$ & $\begin{array}{c}-1.004 * * * \\
(-11.19)\end{array}$ & $\begin{array}{c}-0.251 * * * \\
(-9.63)\end{array}$ & $\begin{array}{c}-0.216 * * * \\
(-8.50)\end{array}$ & $\begin{array}{c}-0.220 * * * \\
(-8.62)\end{array}$ & $\begin{array}{c}-0.135 * * * \\
(-8.21)\end{array}$ \\
\hline Constant & $\begin{array}{c}-6.571 * * * \\
(-5.83)\end{array}$ & $\begin{array}{c}-2.463^{*} \\
(-1.71)\end{array}$ & $\begin{array}{c}-4.055^{* * *} \\
(-3.46)\end{array}$ & $\begin{array}{l}0.831 \\
(1.04)\end{array}$ & $\begin{array}{c}1.234 * * * \\
(3.18)\end{array}$ & $\begin{array}{c}2.098 * * * \\
(6.02)\end{array}$ & $\begin{array}{c}1.564 * * * \\
(2.77)\end{array}$ & $\begin{array}{c}1.656^{* * *} * \\
(7.07)\end{array}$ \\
\hline Year effect & Included & Included & Included & Included & Included & Included & Included & Included \\
\hline $\begin{array}{l}\text { Industry effect } \\
\text { Country effect }\end{array}$ & Included & Included & Included & $\begin{array}{l}\text { Included } \\
\text { Included }\end{array}$ & Included & Included & Included & $\begin{array}{l}\text { Included } \\
\text { Included }\end{array}$ \\
\hline Observations & 53,362 & 47,360 & 53,362 & 53,362 & 53,362 & 47,360 & 53,362 & 53,362 \\
\hline Adj. R-squared & 0.07 & 0.08 & 0.07 & 0.07 & 0.06 & 0.05 & 0.05 & 0.06 \\
\hline
\end{tabular}




\section{Panel B: Using a time-invariant measure of trust}

\begin{tabular}{|c|c|c|}
\hline & $\begin{array}{l}\text { Abnormal Return Variance } \\
\text { (1) }\end{array}$ & $\begin{array}{l}\text { Abnormal Trading Volume } \\
\text { (2) }\end{array}$ \\
\hline Societal Trust (Alternative 1) & $\begin{array}{l}1.807 * * * \\
(8.59)\end{array}$ & $\begin{array}{l}0.366^{* * *} \\
(6.21)\end{array}$ \\
\hline Investor Protection & $\begin{array}{c}1.121 * * * \\
(4.30)\end{array}$ & $\begin{array}{c}0.267 * * * \\
(4.03)\end{array}$ \\
\hline Disclosure Requirement & $\begin{array}{c}4.865 * * * \\
(18.83)\end{array}$ & $\begin{array}{c}1.025^{* * *} \\
(15.07)\end{array}$ \\
\hline Insider Trading & $\begin{array}{l}0.301 \\
(1.50)\end{array}$ & $\begin{array}{l}0.118 \\
(1.37)\end{array}$ \\
\hline Firm Size & $\begin{array}{c}-0.058 * * \\
(-1.98)\end{array}$ & $\begin{array}{c}-0.078 * * * \\
(-10.72)\end{array}$ \\
\hline |UE & $\begin{array}{c}0.787 * * * \\
(4.19)\end{array}$ & $\begin{array}{c}0.161^{* *} \\
(1.99)\end{array}$ \\
\hline Firm Leverage & $\begin{array}{c}0.021 * * \\
(2.08)\end{array}$ & $\begin{array}{c}0.010 * * * \\
(3.49)\end{array}$ \\
\hline Quarterly Reporting & $\begin{array}{c}-0.210 * * \\
(-2.38)\end{array}$ & $\begin{array}{c}-0.043^{*} \\
(-1.73)\end{array}$ \\
\hline Reporting Lag & $\begin{array}{c}-0.010 * * * \\
(-7.03)\end{array}$ & $\begin{array}{c}-0.005^{* * *} \\
(-10.55)\end{array}$ \\
\hline Largest 20 & $\begin{array}{l}-0.003 \\
(-0.02)\end{array}$ & $\begin{array}{l}0.088 \\
(1.47)\end{array}$ \\
\hline Cross Listing & $\begin{array}{l}0.070 \\
(0.53)\end{array}$ & $\begin{array}{l}0.054 \\
(1.63)\end{array}$ \\
\hline Forecast Dispersion & $\begin{array}{c}-0.629 * * \\
(-2.32)\end{array}$ & $\begin{array}{c}-0.506 * * * \\
(-4.57)\end{array}$ \\
\hline Forecast Number & $\begin{array}{c}0.058 * * * \\
(7.91)\end{array}$ & $\begin{array}{l}0.015 * * * \\
(9.41)\end{array}$ \\
\hline Loss Dummy & $\begin{array}{c}-0.966 * * * \\
(-10.82)\end{array}$ & $\begin{array}{c}-0.239 * * * \\
(-9.49)\end{array}$ \\
\hline Constant & $\begin{array}{c}-4.859^{* * *} \\
(-5.23)\end{array}$ & $\begin{array}{c}1.627 * * * \\
(4.36)\end{array}$ \\
\hline Year effect & Included & Included \\
\hline Industry effect & Included & Included \\
\hline Observations & 53,362 & 53,362 \\
\hline Adj. R-squared & 0.07 & 0.05 \\
\hline
\end{tabular}


Panel C: Using a measure of trust based on people's confidence in major companies

\begin{tabular}{|c|c|c|}
\hline & $\begin{array}{c}\text { Abnormal Return Variance } \\
\text { (1) }\end{array}$ & $\begin{array}{c}\text { Abnormal Trading Volume } \\
\text { (2) }\end{array}$ \\
\hline Societal Trust (Alternative 2) & $\begin{array}{l}1.960 * * * \\
(2.81)\end{array}$ & $\begin{array}{c}0.663 * * * \\
(3.39)\end{array}$ \\
\hline Investor Protection & $\begin{array}{l}0.359 \\
(1.24)\end{array}$ & $\begin{array}{l}-0.049 \\
(-1.25)\end{array}$ \\
\hline Disclosure Requirement & $\begin{array}{c}4.311 * * * \\
(14.20)\end{array}$ & $\begin{array}{c}0.742 * * * \\
(9.41)\end{array}$ \\
\hline Insider Trading & $\begin{array}{c}0.493 * * \\
(2.31)\end{array}$ & $\begin{array}{c}0.326 * * * \\
(3.54)\end{array}$ \\
\hline Firm Size & $\begin{array}{c}-0.080 * * * \\
(-2.67)\end{array}$ & $\begin{array}{c}-0.064 * * * \\
(-8.44)\end{array}$ \\
\hline |UE & $\begin{array}{l}0.601 * * * \\
(3.25)\end{array}$ & $\begin{array}{l}0.094 \\
(1.16)\end{array}$ \\
\hline Firm Leverage & $\begin{array}{c}0.021 * * \\
(2.03)\end{array}$ & $\begin{array}{c}0.015 * * * \\
(4.96)\end{array}$ \\
\hline Quarterly Reporting & $\begin{array}{l}0.097 \\
(1.06)\end{array}$ & $\begin{array}{c}0.096 * * * \\
(3.63)\end{array}$ \\
\hline Reporting Lag & $\begin{array}{c}-0.016^{* * * *} \\
(-10.06)\end{array}$ & $\begin{array}{c}-0.004 * * * \\
(-9.53)\end{array}$ \\
\hline Largest 20 & $\begin{array}{l}-0.077 \\
(-0.44)\end{array}$ & $\begin{array}{l}0.071 \\
(1.10)\end{array}$ \\
\hline Cross Listing & $\begin{array}{l}-0.008 \\
(-0.05)\end{array}$ & $\begin{array}{l}-0.009 \\
(-0.26)\end{array}$ \\
\hline Forecast Dispersion & $\begin{array}{l}-0.443 \\
(-1.64)\end{array}$ & $\begin{array}{c}-0.492 * * * \\
(-4.43)\end{array}$ \\
\hline Forecast Number & $\begin{array}{c}0.060 * * * \\
(7.80)\end{array}$ & $\begin{array}{c}0.011 * * * \\
(6.70)\end{array}$ \\
\hline Loss Dummy & $\begin{array}{c}-0.924 * * * \\
(-10.26)\end{array}$ & $\begin{array}{c}-0.257 * * * \\
(-9.99)\end{array}$ \\
\hline Constant & $\begin{array}{c}-2.526 * * \\
(-2.34)\end{array}$ & $\begin{array}{c}-0.583^{*} \\
(-1.86)\end{array}$ \\
\hline Year effect & Included & Included \\
\hline Industry effect & Included & Included \\
\hline Observations & 50,175 & 50,175 \\
\hline Adj. R-squared & 0.07 & 0.06 \\
\hline
\end{tabular}




\section{Panel D: Different event windows for measuring investor reactions to earnings announcements}

\begin{tabular}{|c|c|c|c|c|c|c|}
\hline & \multicolumn{3}{|c|}{ Abnormal Return Variance } & \multicolumn{3}{|c|}{ Abnormal Trading Volume } \\
\hline & (1) & (2) & (3) & (4) & $(5)$ & (6) \\
\hline & Abvar $(-1,+1)$ & Abvar $(0,+2)$ & Abvar $(-2,+2)$ & Abvol $(-1,+1)$ & Abvol $(0,+2)$ & Abvol $(-2,+2)$ \\
\hline Investor Protection & $\begin{array}{c}1.000 * * * \\
(5.42)\end{array}$ & $\begin{array}{c}0.796 * * * \\
(4.28)\end{array}$ & $\begin{array}{c}0.627 * * * \\
(5.04)\end{array}$ & $\begin{array}{c}0.152 * * * \\
(2.94)\end{array}$ & $\begin{array}{c}0.189 * * * \\
(3.36)\end{array}$ & $\begin{array}{l}0.065 \\
(1.55)\end{array}$ \\
\hline Disclosure Requirement & $\begin{array}{c}3.287 * * * \\
(17.42)\end{array}$ & $\begin{array}{c}3.494 * * * \\
(17.96)\end{array}$ & $\begin{array}{c}2.011 * * * \\
(15.69)\end{array}$ & $\begin{array}{c}0.663 * * * \\
(12.19)\end{array}$ & $\begin{array}{c}0.769 * * * \\
(13.17)\end{array}$ & $\begin{array}{c}0.427 * * * \\
(9.68)\end{array}$ \\
\hline Insider Trading & $\begin{array}{l}0.001 \\
(0.00)\end{array}$ & $\begin{array}{l}0.116 \\
(0.74)\end{array}$ & $\begin{array}{c}0.031 \\
(0.26)\end{array}$ & $\begin{array}{c}0.155^{*} \\
(1.90)\end{array}$ & $\begin{array}{l}0.070 \\
(0.93)\end{array}$ & $\begin{array}{c}0.157 * * \\
(2.29)\end{array}$ \\
\hline Firm Size & $\begin{array}{c}-0.056 * * * \\
(-2.73)\end{array}$ & $\begin{array}{c}-0.066 * * * \\
(-3.15)\end{array}$ & $\begin{array}{c}-0.050 * * * \\
(-3.55)\end{array}$ & $\begin{array}{c}-0.055^{* * *} * \\
(-9.57)\end{array}$ & $\begin{array}{c}-0.070 * * * \\
(-11.18)\end{array}$ & $\begin{array}{c}-0.041 * * * \\
(-8.66)\end{array}$ \\
\hline |UE & $\begin{array}{c}0.521 * * * \\
(3.70)\end{array}$ & $\begin{array}{c}0.711 * * * \\
(4.37)\end{array}$ & $\begin{array}{c}0.461 * * * \\
(4.11)\end{array}$ & $\begin{array}{l}0.100 \\
(1.57)\end{array}$ & $\begin{array}{c}0.155^{* *} \\
(2.24)\end{array}$ & $\begin{array}{c}0.093 * \\
(1.81)\end{array}$ \\
\hline Firm Leverage & $\begin{array}{c}0.019 * * * \\
(2.64)\end{array}$ & $\begin{array}{c}0.017 * * \\
(2.24)\end{array}$ & $\begin{array}{c}0.016 * * * \\
(3.11)\end{array}$ & $\begin{array}{c}0.009 * * * \\
(3.92)\end{array}$ & $\begin{array}{c}0.008 * * * \\
(2.89)\end{array}$ & $\begin{array}{c}0.007 * * * \\
(3.31)\end{array}$ \\
\hline Reporting Lag & $\begin{array}{c}-0.007 * * * \\
(-6.66)\end{array}$ & $\begin{array}{c}-0.008 * * * \\
(-7.10)\end{array}$ & $\begin{array}{c}-0.005 * * * \\
(-6.25)\end{array}$ & $\begin{array}{c}-0.003 * * * * \\
(-10.07)\end{array}$ & $\begin{array}{c}-0.004 * * * \\
(-11.38)\end{array}$ & $\begin{array}{c}-0.003 * * * \\
(-9.96)\end{array}$ \\
\hline Largest 20 & $\begin{array}{l}-0.014 \\
(-0.11)\end{array}$ & $\begin{array}{l}-0.034 \\
(-0.27)\end{array}$ & $\begin{array}{l}-0.029 \\
(-0.34)\end{array}$ & $\begin{array}{c}0.079 * \\
(1.68)\end{array}$ & $\begin{array}{l}0.057 \\
(1.08)\end{array}$ & $\begin{array}{c}0.068^{*} \\
(1.73)\end{array}$ \\
\hline Cross Listing & $\begin{array}{l}0.038 \\
(0.40)\end{array}$ & $\begin{array}{l}0.110 \\
(1.14)\end{array}$ & $\begin{array}{l}0.032 \\
(0.51)\end{array}$ & $\begin{array}{l}0.039 \\
(1.49)\end{array}$ & $\begin{array}{l}0.024 \\
(0.87)\end{array}$ & $\begin{array}{l}0.019 \\
(0.91)\end{array}$ \\
\hline Forecast Dispersion & $\begin{array}{c}-0.446 * * \\
(-2.10)\end{array}$ & $\begin{array}{c}-0.726 * * * \\
(-3.36)\end{array}$ & $\begin{array}{c}-0.511 * * * \\
(-3.32)\end{array}$ & $\begin{array}{c}-0.431 * * * \\
(-4.91)\end{array}$ & $\begin{array}{c}-0.478 * * * \\
(-4.98)\end{array}$ & $\begin{array}{c}-0.385 * * * \\
(-5.22)\end{array}$ \\
\hline Forecast Number & $\begin{array}{c}0.043 * * * \\
(8.21)\end{array}$ & $\begin{array}{c}0.041 * * * \\
(7.66)\end{array}$ & $\begin{array}{c}0.026 * * * \\
(7.41)\end{array}$ & $\begin{array}{c}0.011 * * * \\
(9.13)\end{array}$ & $\begin{array}{c}0.010 * * * \\
(7.39)\end{array}$ & $\begin{array}{c}0.007 * * * \\
(6.68)\end{array}$ \\
\hline Loss Dummy & $\begin{array}{c}-0.692 * * * \\
(-10.90)\end{array}$ & $\begin{array}{c}-0.699 * * * \\
(-10.71)\end{array}$ & $\begin{array}{c}-0.449 * * * \\
(-10.27)\end{array}$ & $\begin{array}{c}-0.155^{* * * *} \\
(-7.79)\end{array}$ & $\begin{array}{c}-0.206^{* * * *} \\
(-9.48)\end{array}$ & $\begin{array}{c}-0.114 * * * \\
(-6.81)\end{array}$ \\
\hline Constant & $\begin{array}{c}-2.492 * * * \\
(-3.73)\end{array}$ & $\begin{array}{c}-2.458 * * * \\
(-3.15)\end{array}$ & $\begin{array}{l}-0.610 \\
(-1.05)\end{array}$ & $\begin{array}{c}1.624 * * * \\
(6.02)\end{array}$ & $\begin{array}{c}1.870 * * * \\
(5.74)\end{array}$ & $\begin{array}{c}1.670 * * * \\
(7.57)\end{array}$ \\
\hline
\end{tabular}




\section{Panel E: Regression analysis based on country-year average values of variables}

This panel summarizes the estimation results of equation (1) where all firm-specific variables take on the value of their respective country-year averages.

\begin{tabular}{lcc}
\hline & Abnormal Return Variance & Abnormal Trading Volume \\
\hline & $(1)$ & $(2)$ \\
\hline Societal Trust & $4.270^{* * *}$ & $0.965^{* *}$ \\
Investor Protection & $(4.56)$ & $(2.21)$ \\
& 0.791 & -0.025 \\
Disclosure Requirement & $0.59)$ & $(-0.06)$ \\
Insider Trading & 0.847 & 0.025 \\
& $(0.56)$ & $(0.05)$ \\
Firm Size & 0.070 & 0.281 \\
& $(0.10)$ & $(0.93)$ \\
|UE| & -0.261 & $-0.180^{*}$ \\
& $(-1.04)$ & $(-2.07)$ \\
Firm Leverage & 0.264 & 0.151 \\
& $(1.09)$ & $(1.56)$ \\
Quarterly Reporting & -0.020 & 0.003 \\
& $(-0.09)$ & $(0.04)$ \\
Reporting Lag & -0.494 & -0.071 \\
& $(-1.00)$ & $(-0.46)$ \\
Largest 20 & $-0.025^{* *}$ & $-0.008^{* *}$ \\
& $(-2.56)$ & $(-2.28)$ \\
Cross Listing & $-5.156^{* *}$ & -1.227 \\
Forecast Dispersion & $(-2.39)$ & $(-1.43)$ \\
Forecast Number & -0.251 & -0.258 \\
Loss Dummy & $(-0.16)$ & $(-0.43)$ \\
Constant & $-0.772^{* * *}$ & -0.403 \\
& $(-3.32)$ & $(-0.42)$ \\
Year effect & 0.082 & 0.012 \\
Observations & $(1.59)$ & $(0.49)$ \\
Adj. R-squared & -2.644 & -0.410 \\
& $(-1.02)$ & $(-0.44)$ \\
& 3.327 & $3.923^{* *}$ \\
& $(0.70)$ & $(2.44)$ \\
& Included & 191 \\
& 191 & 0.39 \\
\hline
\end{tabular}


Panel F: Alternative sample selections

\begin{tabular}{|c|c|c|c|c|c|c|c|c|}
\hline & \multicolumn{4}{|c|}{ Abnormal Return Variance } & \multicolumn{4}{|c|}{ Abnormal Trading Volume } \\
\hline & (1) & $(2)$ & (3) & (4) & $(5)$ & (6) & $(7)$ & $(8)$ \\
\hline & $\begin{array}{l}\text { US firms } \\
\text { excluded }\end{array}$ & $\begin{array}{l}\text { JPN firms } \\
\text { excluded }\end{array}$ & $\begin{array}{l}\text { UK firms } \\
\text { excluded }\end{array}$ & $\begin{array}{l}\text { US, JPN, and } \\
\text { UK firms } \\
\text { excluded }\end{array}$ & $\begin{array}{l}\text { US firms } \\
\text { excluded }\end{array}$ & $\begin{array}{l}\text { JPN firms } \\
\text { excluded }\end{array}$ & $\begin{array}{l}\text { UK firms } \\
\text { excluded }\end{array}$ & $\begin{array}{l}\text { US, JPN, and } \\
\text { UK firms } \\
\text { excluded }\end{array}$ \\
\hline Societal Trust & $\begin{array}{c}1.305 * * * \\
(2.71)\end{array}$ & $\begin{array}{c}4.531 * * * \\
(9.84)\end{array}$ & $\begin{array}{c}5.889^{* * *} \\
(12.87)\end{array}$ & $\begin{array}{c}3.371^{* * * *} \\
(6.46)\end{array}$ & $\begin{array}{c}0.248 * * \\
(2.55)\end{array}$ & $\begin{array}{c}0.734 * * * \\
(5.86)\end{array}$ & $\begin{array}{c}1.057 * * * \\
(8.42)\end{array}$ & $\begin{array}{c}0.738^{* * * *} \\
(5.17)\end{array}$ \\
\hline Investor Protection & $\begin{array}{c}2.530 * * * \\
(8.93)\end{array}$ & $\begin{array}{c}0.701 * * * \\
(2.61)\end{array}$ & $\begin{array}{c}-1.422 * * * \\
(-4.61)\end{array}$ & $\begin{array}{c}0.315^{* *} \\
(2.07)\end{array}$ & $\begin{array}{c}0.268 * * * \\
(6.18)\end{array}$ & $\begin{array}{c}0.199 * * * \\
(2.95)\end{array}$ & $\begin{array}{c}-0.334 * * * \\
(-4.30)\end{array}$ & $\begin{array}{l}0.024 \\
(0.54)\end{array}$ \\
\hline Disclosure Requirement & $\begin{array}{c}0.986 * * \\
(2.57)\end{array}$ & $\begin{array}{c}4.477 * * * \\
(16.02)\end{array}$ & $\begin{array}{c}4.442 * * * \\
(16.51)\end{array}$ & $\begin{array}{c}1.066 * * \\
(2.50)\end{array}$ & $\begin{array}{l}0.066 \\
(0.85)\end{array}$ & $\begin{array}{c}0.745^{* * * *} \\
(9.87)\end{array}$ & $\begin{array}{c}0.860 * * * \\
(12.07)\end{array}$ & $\begin{array}{c}0.273 * * \\
(2.34)\end{array}$ \\
\hline Insider Trading & $\begin{array}{l}-0.194 \\
(-0.89)\end{array}$ & $\begin{array}{l}0.090 \\
(0.43)\end{array}$ & $\begin{array}{c}0.643 * * * \\
(3.15)\end{array}$ & $\begin{array}{l}-0.106 \\
(-0.37)\end{array}$ & $\begin{array}{c}0.255^{* * * *} \\
(3.94)\end{array}$ & $\begin{array}{l}0.030 \\
(0.34)\end{array}$ & $\begin{array}{c}0.200 * * \\
(2.31)\end{array}$ & $\begin{array}{c}0.349 * * * \\
(2.84)\end{array}$ \\
\hline Firm Size & $\begin{array}{c}-0.186 * * * \\
(-4.65)\end{array}$ & $\begin{array}{l}-0.013 \\
(-0.38)\end{array}$ & $\begin{array}{c}-0.060 * * \\
(-2.05)\end{array}$ & $\begin{array}{l}-0.068 \\
(-1.24)\end{array}$ & $\begin{array}{c}-0.044 * * * \\
(-5.44)\end{array}$ & $\begin{array}{c}-0.054 * * * \\
(-6.63)\end{array}$ & $\begin{array}{c}-0.085 * * * \\
(-11.59)\end{array}$ & $\begin{array}{c}-0.073 * * * \\
(-5.04)\end{array}$ \\
\hline$|\mathrm{UE}|$ & $\begin{array}{l}0.200 \\
(1.04)\end{array}$ & $\begin{array}{c}0.822 * * * \\
(4.31)\end{array}$ & $\begin{array}{c}0.761 * * * \\
(4.11)\end{array}$ & $\begin{array}{l}0.330 \\
(1.62)\end{array}$ & $\begin{array}{l}0.077 \\
(1.44)\end{array}$ & $\begin{array}{c}0.174 * * \\
(2.13)\end{array}$ & $\begin{array}{c}0.152 * \\
(1.88)\end{array}$ & $\begin{array}{l}0.104 \\
(1.04)\end{array}$ \\
\hline Firm Leverage & $\begin{array}{c}0.024 * * \\
(2.06)\end{array}$ & $\begin{array}{c}0.036 * * * \\
(3.20)\end{array}$ & $\begin{array}{c}0.018 * \\
(1.69)\end{array}$ & $\begin{array}{c}0.032 * * \\
(2.03)\end{array}$ & $\begin{array}{c}0.012 * * * \\
(3.71)\end{array}$ & $\begin{array}{c}0.013 * * * \\
(3.87)\end{array}$ & $\begin{array}{c}0.009 * * * \\
(2.93)\end{array}$ & $\begin{array}{c}0.011 * * \\
(2.02)\end{array}$ \\
\hline Quarterly Reporting & $\begin{array}{c}-0.476 * * * \\
(-4.16)\end{array}$ & $\begin{array}{c}-0.562 * * * \\
(-5.00)\end{array}$ & $\begin{array}{c}0.203^{* *} * \\
(2.30)\end{array}$ & $\begin{array}{c}-0.450 * * * \\
(-3.13)\end{array}$ & $\begin{array}{c}-0.104 * * * \\
(-4.67)\end{array}$ & $\begin{array}{c}-0.078 * * * \\
(-2.60)\end{array}$ & $\begin{array}{c}0.074 * * * \\
(2.81)\end{array}$ & $\begin{array}{l}-0.002 \\
(-0.04)\end{array}$ \\
\hline Reporting Lag & $\begin{array}{c}-0.012 * * * \\
(-7.07)\end{array}$ & $\begin{array}{c}-0.013 * * * \\
(-8.12)\end{array}$ & $\begin{array}{c}-0.014 * * * \\
(-8.84)\end{array}$ & $\begin{array}{c}-0.016 \text { *** } \\
(-8.91)\end{array}$ & $\begin{array}{c}-0.006 * * * \\
(-15.59)\end{array}$ & $\begin{array}{c}-0.005 * * * \\
(-11.46)\end{array}$ & $\begin{array}{c}-0.005 * * * \\
(-12.28)\end{array}$ & $\begin{array}{c}-0.008 * * * \\
(-13.09)\end{array}$ \\
\hline Largest 20 & $\begin{array}{l}0.047 \\
(0.25)\end{array}$ & $\begin{array}{l}-0.104 \\
(-0.59)\end{array}$ & $\begin{array}{l}0.002 \\
(0.02)\end{array}$ & $\begin{array}{l}0.217 \\
(1.14)\end{array}$ & $\begin{array}{l}0.040 \\
(0.96)\end{array}$ & $\begin{array}{l}0.055 \\
(0.88)\end{array}$ & $\begin{array}{c}0.103^{*} \\
(1.71)\end{array}$ & $\begin{array}{c}0.157 * * \\
(2.23)\end{array}$ \\
\hline Cross Listing & $\begin{array}{c}0.292 * * \\
(2.10)\end{array}$ & $\begin{array}{l}0.192 \\
(1.25)\end{array}$ & $\begin{array}{l}0.008 \\
(0.05)\end{array}$ & $\begin{array}{l}0.217 \\
(1.25)\end{array}$ & $\begin{array}{l}0.035 \\
(1.28)\end{array}$ & $\begin{array}{c}0.076 * * \\
(2.04)\end{array}$ & $\begin{array}{l}0.024 \\
(0.66)\end{array}$ & $\begin{array}{l}0.029 \\
(0.65)\end{array}$ \\
\hline Forecast Dispersion & $\begin{array}{c}-0.795 * * * \\
(-2.90)\end{array}$ & $\begin{array}{c}-0.742 * * * \\
(-2.68)\end{array}$ & $\begin{array}{l}-0.353 \\
(-1.32)\end{array}$ & $\begin{array}{l}-0.438 \\
(-1.58)\end{array}$ & $\begin{array}{c}-0.421 * * * \\
(-5.66)\end{array}$ & $\begin{array}{c}-0.542 * * * \\
(-4.83)\end{array}$ & $\begin{array}{c}-0.443 * * * \\
(-4.01)\end{array}$ & $\begin{array}{c}-0.393 * * * \\
(-3.03)\end{array}$ \\
\hline Forecast Number & $\begin{array}{c}0.064 * * * \\
(6.54)\end{array}$ & $\begin{array}{c}0.050 * * * \\
(6.13)\end{array}$ & $\begin{array}{c}0.059 * * * \\
(7.79)\end{array}$ & $\begin{array}{c}0.069 * * * \\
(5.98)\end{array}$ & $\begin{array}{c}0.015^{* * *} \\
(8.50)\end{array}$ & $\begin{array}{c}0.009 * * * \\
(5.19)\end{array}$ & $\begin{array}{c}0.016 * * * \\
(9.59)\end{array}$ & $\begin{array}{c}0.017 * * * \\
(5.95)\end{array}$ \\
\hline Loss Dummy & $\begin{array}{c}-0.648 * * * \\
(-5.39)\end{array}$ & $\begin{array}{c}-0.976 * * * \\
(-9.59)\end{array}$ & $\begin{array}{c}-0.925 * * * \\
(-10.18)\end{array}$ & $\begin{array}{c}-0.397 * * \\
(-2.34)\end{array}$ & $\begin{array}{c}-0.123 * * * \\
(-4.53)\end{array}$ & $\begin{array}{c}-0.240 * * * \\
(-8.58)\end{array}$ & $\begin{array}{c}-0.241 * * * \\
(-9.48)\end{array}$ & $\begin{array}{c}-0.167 * * * \\
(-3.15)\end{array}$ \\
\hline Constant & $\begin{array}{l}1.675 \\
(1.13)\end{array}$ & $\begin{array}{c}-4.610 * * * \\
(-5.02)\end{array}$ & $\begin{array}{l}-1.244 \\
(-1.35)\end{array}$ & $\begin{array}{l}0.806 \\
(0.77)\end{array}$ & $\begin{array}{c}1.504 * * * \\
(4.59)\end{array}$ & $\begin{array}{c}1.789 * * * \\
(4.71)\end{array}$ & $\begin{array}{c}2.683 * * * \\
(6.87)\end{array}$ & $\begin{array}{c}2.492 * * * \\
(4.35)\end{array}$ \\
\hline Year effect & Included & Included & Included & Included & Included & Included & Included & Included \\
\hline
\end{tabular}




\begin{tabular}{|c|c|c|c|c|c|c|c|c|}
\hline Industry effect & Included & Included & Included & Included & Included & Included & Included & Included \\
\hline Observations & 25,505 & 46,645 & 49,365 & 14,791 & 25,505 & 46,645 & 49,365 & 14,791 \\
\hline Adj. R-squared & 0.05 & 0.07 & 0.08 & 0.05 & 0.05 & 0.05 & 0.06 & 0.06 \\
\hline
\end{tabular}


Panel G: Log and rank transformation of dependent variables

\begin{tabular}{|c|c|c|c|c|}
\hline & \multicolumn{2}{|c|}{ Log transformation } & \multicolumn{2}{|c|}{ Rank transformation } \\
\hline & (1) & (2) & (3) & (4) \\
\hline & $\begin{array}{c}\text { Abnormal Return } \\
\text { Variance }\end{array}$ & $\begin{array}{c}\text { Abnormal Trading } \\
\text { Volume }\end{array}$ & $\begin{array}{c}\text { Abnormal Return } \\
\text { Variance }\end{array}$ & $\begin{array}{c}\text { Abnormal Trading } \\
\text { Volume }\end{array}$ \\
\hline Societal Trust & $\begin{array}{c}0.930 * * * \\
(7.60)\end{array}$ & $\begin{array}{c}0.488 * * * \\
(7.38)\end{array}$ & $\begin{array}{c}1.493 * * * \\
(7.67)\end{array}$ & $\begin{array}{c}1.858 * * * \\
(8.55)\end{array}$ \\
\hline Investor Protection & $\begin{array}{c}0.310 * * * \\
(4.73)\end{array}$ & $\begin{array}{c}0.060 * \\
(1.76)\end{array}$ & $\begin{array}{l}0.559 * * * \\
(5.35)\end{array}$ & $\begin{array}{l}0.128 \\
(1.13)\end{array}$ \\
\hline Disclosure Requirement & $\begin{array}{c}1.384 * * * \\
(19.67)\end{array}$ & $\begin{array}{c}0.755^{* * *} * \\
(20.73)\end{array}$ & $\begin{array}{c}2.365 * * * \\
(20.93)\end{array}$ & $\begin{array}{c}2.818 * * * \\
(22.88)\end{array}$ \\
\hline Insider Trading & $\begin{array}{l}-0.144 \\
(-1.47)\end{array}$ & $\begin{array}{l}-0.008 \\
(-0.17)\end{array}$ & $\begin{array}{l}-0.200 \\
(-1.31)\end{array}$ & $\begin{array}{l}0.099 \\
(0.68)\end{array}$ \\
\hline Firm Size & $\begin{array}{c}0.022 * * * \\
(2.84)\end{array}$ & $\begin{array}{c}0.019 * * * \\
(4.98)\end{array}$ & $\begin{array}{l}0.023 * \\
(1.88)\end{array}$ & $\begin{array}{c}0.055^{* * *} * \\
(4.17)\end{array}$ \\
\hline$|\mathrm{UE}|$ & $\begin{array}{c}0.259 * * * \\
(4.04)\end{array}$ & $\begin{array}{c}0.087 * * \\
(2.42)\end{array}$ & $\begin{array}{c}0.441 * * * \\
(4.24)\end{array}$ & $\begin{array}{c}0.323 * * * \\
(2.95)\end{array}$ \\
\hline Firm Leverage & $\begin{array}{c}0.007 * * \\
(2.17)\end{array}$ & $\begin{array}{c}0.008 * * * \\
(5.14)\end{array}$ & $\begin{array}{c}0.013 * * \\
(2.48)\end{array}$ & $\begin{array}{c}0.021 * * * \\
(3.98)\end{array}$ \\
\hline Quarterly Reporting & $\begin{array}{l}-0.030 \\
(-1.20)\end{array}$ & $\begin{array}{l}-0.019 \\
(-1.51)\end{array}$ & $\begin{array}{c}-0.086 * * \\
(-2.15)\end{array}$ & $\begin{array}{l}-0.030 \\
(-0.70)\end{array}$ \\
\hline Reporting Lag & $\begin{array}{c}-0.006 * * * \\
(-14.46)\end{array}$ & $\begin{array}{c}-0.004 * * * \\
(-17.91)\end{array}$ & $\begin{array}{c}-0.010 * * * \\
(-15.12)\end{array}$ & $\begin{array}{c}-0.014 * * * \\
(-18.58)\end{array}$ \\
\hline Largest 20 & $\begin{array}{l}-0.038 \\
(-0.78)\end{array}$ & $\begin{array}{l}-0.032 \\
(-1.09)\end{array}$ & $\begin{array}{l}0.040 \\
(0.54)\end{array}$ & $\begin{array}{l}0.087 \\
(1.01)\end{array}$ \\
\hline Cross Listing & $\begin{array}{l}0.078 * * \\
(2.01)\end{array}$ & $\begin{array}{l}0.033 * \\
(1.78)\end{array}$ & $\begin{array}{l}0.120 * \\
(1.88)\end{array}$ & $\begin{array}{l}0.078 \\
(1.12)\end{array}$ \\
\hline Forecast Dispersion & $\begin{array}{c}-0.391 * * * \\
(-3.30)\end{array}$ & $\begin{array}{c}-0.265 * * * \\
(-4.75)\end{array}$ & $\begin{array}{c}-0.657 * * * \\
(-3.76)\end{array}$ & $\begin{array}{c}-0.863 * * * \\
(-4.92)\end{array}$ \\
\hline Forecast Number & $\begin{array}{c}0.018 * * * \\
(10.14)\end{array}$ & $\begin{array}{c}0.010 * * * \\
(11.63)\end{array}$ & $\begin{array}{c}0.032 * * * \\
(10.58)\end{array}$ & $\begin{array}{c}0.037 * * * \\
(12.59)\end{array}$ \\
\hline Loss Dummy & $\begin{array}{c}-0.242 * * * \\
(-9.45)\end{array}$ & $\begin{array}{c}-0.118 * * * \\
(-9.36)\end{array}$ & $\begin{array}{c}-0.423 * * * \\
(-10.19)\end{array}$ & $\begin{array}{c}-0.437 * * * \\
(-10.29)\end{array}$ \\
\hline Constant & $\begin{array}{c}-2.680 * * * \\
(-7.77)\end{array}$ & $\begin{array}{c}-0.949 * * * \\
(-4.64)\end{array}$ & $\begin{array}{l}0.303 \\
(0.54)\end{array}$ & $\begin{array}{l}0.664 \\
(1.00)\end{array}$ \\
\hline Year effect & Included & Included & Included & Included \\
\hline Industry effect & Included & Included & Included & Included \\
\hline Observations & 53,362 & 53,362 & 53,362 & 53,362 \\
\hline Adj. R-squared & 0.09 & 0.10 & 0.05 & 0.08 \\
\hline
\end{tabular}

